\title{
EMPIRICAL INVESTIGATION OF THE FOREIGN MARKET EXPANSION AND SURVIVAL OF CANADIAN EXPORTERS
}

\author{
By \\ Sui Sui \\ A thesis submitted to \\ The Faculty of Graduate Studies and Research of Carleton University \\ In partial fulfillment of the requirement for the degree of \\ Doctor of Philosophy
}

Department of Economics

Carleton University

Ottawa, Canada

CCopyright 2010. Sui Sui 


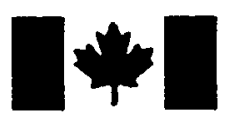

Library and Archives Canada

Published Heritage

Branch

395 Wellington Street Ottawa ON K1A ON4 Canada
Bibliotheqque et

Archives Canada

Direction du

Patrimoine de l'édition

395 , rue Wellington

Ottawa ON K1A ON4

Canada
Your file Votre reférence
ISBN: 978-0-494-67886-2
Our file Notre reférence
ISBN: $978-0-494-67886-2$
NOTICE:

The author has granted a nonexclusive license allowing Library and Archives Canada to reproduce, publish, archive, preserve, conserve, communicate to the public by telecommunication or on the Internet, loan, distribute and sell theses worldwide, for commercial or noncommercial purposes, in microform, paper, electronic and/or any other formats.

The author retains copyright ownership and moral rights in this thesis. Neither the thesis nor substantial extracts from it may be printed or otherwise reproduced without the author's permission.
AVIS:

L'auteur a accordé une licence non exclusive permettant à la Bibliothèque et Archives Canada de reproduire, publier, archiver, sauvegarder, conserver, transmettre au public par télécommunication ou par l'Internet, prêter, distribuer et vendre des thèses partout dans le monde, à des fins commerciales ou autres, sur support microforme, papier, électronique et/ou autres formats.

L'auteur conserve la propriété du droit d'auteur et des droits moraux qui protège cette thèse. Ni la thèse ni des extraits substantiels de celle-ci ne doivent être imprimés ou autrement reproduits sans son autorisation.
In compliance with the Canadian Privacy Act some supporting forms may have been removed from this thesis.

While these forms may be included in the document page count, their removal does not represent any loss of content from the thesis.
Conformément à la loi canadienne sur la protection de la vie privée, quelques formulaires secondaires ont été enlevés de cette thèse.

Bien que ces formulaires aient inclus dans la pagination, il n'y aura aucun contenu manquant.

\section{Canadä}




\section{Dedication}

This dissertation is dedicated to my parents, Yan-Yun Wang and Zong-Wei Sui, without whose unconditional love and longstanding support I would have never accomplished this goal.

Translation in Chinese:

\section{致谢词}

谨以此论文献给我的母亲王艳云和父亲隋宗维，没有他们无私的爱

和长期的支持，我将不可能实现这一目标。 


\begin{abstract}
This thesis contains four chapters with its main theme being related to the international trade and business activities of Canadian firms. The unique firm-level longitudinal data set that is used in both essays was built by the author upon multiple administrative databases from Statistics Canada. Due to confidentiality reasons, the access of this data set is restricted to other researchers. To ensure that the research community will be able to construct the same data set, Chapter 1 presents the data set documentation.
\end{abstract}

Chapter 2 investigates the dynamics of the sequential expansion of Canadian exporters into different foreign markets, and how the characteristics of firms affect their choice of different geographical expansion strategies. A multinomial logit model is applied on a sample of 3,257 Canadian exporters for the period of 1993-2005. It appears that the majority of Canadian exporters chose the U.S. as their first export destination during the period of this study. This result supports the prediction of the stage model that Canadian firms export to the U.S. before they export to the rest of the world. The probability for a new exporter to adopt alternative expansion patterns, such as a focus on non-U.S. markets as their first export destination, or exporting to both the U.S. and non-U.S. markets simultaneously has increased dramatically over time. This evidence suggests that the traditional stage internationalization process is not universal to all firms. Moreover, there is a considerable and growing minority of firms that violate the stage model.

Applying the duration analysis on 1,959 newly established small and medium-sized Canadian exporting manufacturers, Chapter 3 compares the survivability of Born Global 
and Gradual Global firms in the export market. With all else held constant, the probability of survival of Born Global is six percent lower than Gradual Global firms. Once the endogeneity of a firm's choice of its internationalization process is incorporated into the analysis, differences in survival probabilities disappear. Further, the results show that Born Global and Gradual Global firms have notably different advantages and disadvantages while competing in the global export market. These findings have important implications for both academic researchers and policy-makers.

Finally, concluding remarks are discussed in Chapter 4. 


\section{Acknowledgement}

I owe my most sincere gratitude to my thesis advisor, Dr. Zhihao Yu for his continuous support in the Ph.D. program. Zhihao created many opportunities for me to improve my research skills. For example, he suggested that I apply for Statistics Canada's Tom Symons Research Fellowship. Zhihao also taught me how to approach a research problem, how to write good academic papers, and how to be persistent in order to accomplish any goals. I am fortunate to have Dr. Marcel-Cristian Voia, who taught me how to conduct empirical research and helped to make me a better STATA programmer. Marcel was always available to meet with me and provided detailed and constructive comments. I would not be able to finish my thesis without Marcel's support.

I am deeply grateful to the supervisor of the joint Ph.D. program, Dr. Christopher Worswick, for his fairness, patience and thoughtfulness. I would like to thank the other members of my committee. Dr. Louis-Philippe Morin, who tested me by asking good research questions as well as getting me to explain the econometric theories that lie behind them. Dr. Zhiqi Chen, whose academic support and input are greatly appreciated. Zhiqi is the one who accepted me into the Ph.D. program. Gratitude is also given to Dr. Yanling Wang and Dr. Susan Chun Zhu who carefully reviewed the paper and provided very useful suggestions.

I want to thank many faculty members in the Department of Economics at Carleton University. In particular, Dr. Frances Woolley shared her editorial expertise and taught me how to pay attention to details. Frances has been a friend and mentor ever since I came to Canada. I would like to give a heartfelt, special thanks to Dr. Lynda Khalaf. 
Lynda is incredibly energetic and inspirational. She gave me the best advice I ever received. I wish to express my sincere thanks to Dr. Huntley Schaller, Dr. Keir Armstrong, Dr. Fanny Demers, Dr. Michel Demers, Dr. Vivek Dehejia, Dr. Hashmat Khan, Dr. Ana Dammert, Dr. Mariko Klasing, and Dr. Ba Chu, whose insightful consultations and warm encouragements were precious during the writing of this thesis. I want to express my appreciation to the administration team at the department, especially, Dawn Bjornson, Marge Brooks, and Erin Johnston. Thank you for having confidence in me and for supporting my research, teaching, and job-seeking activities. You made the department a wonderful workplace and home for me.

I would like to thank Statistics Canada's International Trade Division, in particular, Craig Kuntz, Philip Armstrong, Philip Jorre de St. Jorre, Evelyn Simpson, and Marc Nadeau, for the support in working with the Exporter Registry Database under the Tom Symons Research Fellowship. I greatly acknowledge the permission of Statistic Canada's Business Research Coordinating Committee to access the data used in this thesis. Additional thanks to Dr. Keith Head, Dr. Francis Kramarz, Dr. John R. Baldwin, Yvan Gervais, Dr. Jean-Bosco Sabuhoro, Dr. Wulong Gu, Dr. Loretta Fung, Dr. Lenka Mach, and other participants in the seminars and workshops at Statistics Canada. This thesis represents the views of the author and does not necessarily reflect the opinion of Statistics Canada.

Special thanks go to Sean Horne, for his great help with proofreading the manuscript, and for his patience and support. Last but not least, I deeply appreciate my parents, family, teachers, and friends, who are my source of emotional support throughout this entire process. Thank you all! 


\section{Table of Contents}

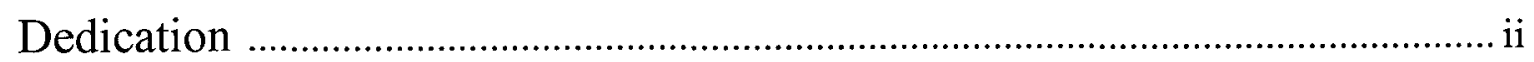

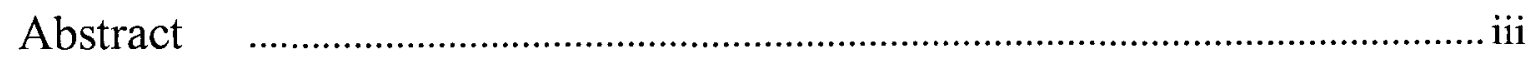

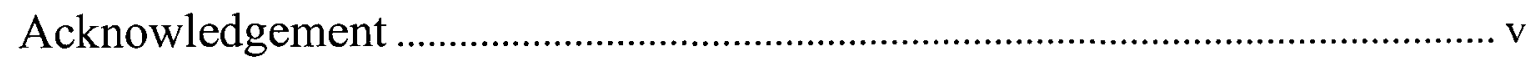

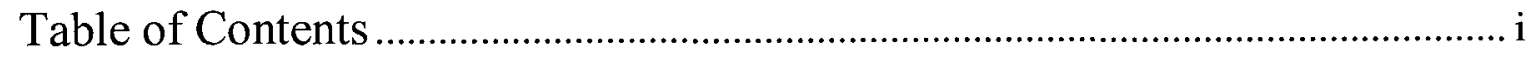

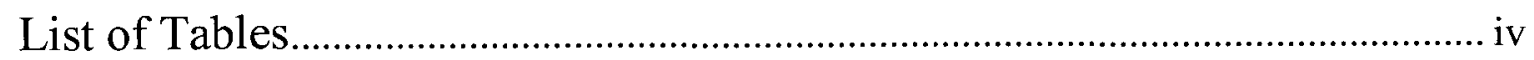

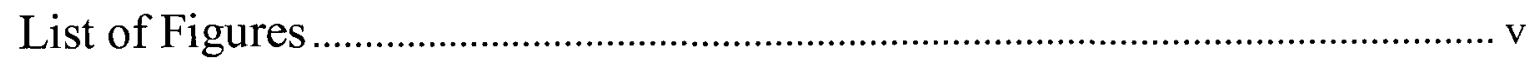

Chapter 1 Data Set Documentation............................................................. 1

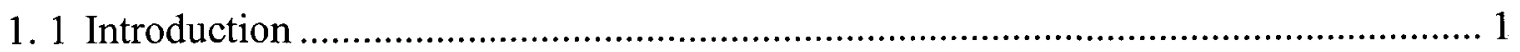

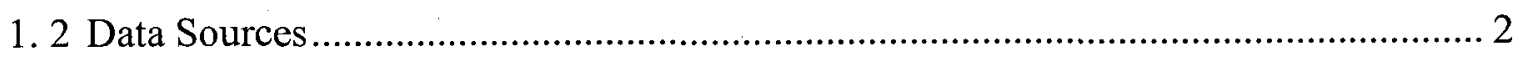

1.2.1 The Exporter Register............................................................................. 2

1.2.2 The Business Register ............................................................................. 5

1.2.3 The Longitudinal Employment Analysis Program.......................................... 5

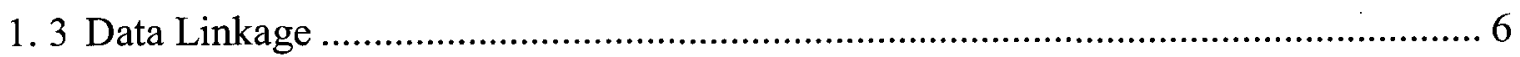

1.3.1 Aggregation across Establishments in the ER Database ……........................... 7

1.3.2 Aggregation across Provinces in the LEAP Database ....................................... 8

1.3.3 Merging the ER, the BR and the LEAP Databases ...................................... 8

1. 4 Construction of the Variables of Interest ................................................................ 9

1.5 Error Detection and Imputation................................................................... 13

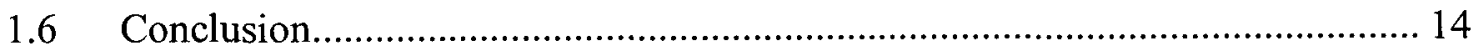

Chapter 2 A Multinomial Logit Analysis of Foreign Market Expansion of Canadian Exporters .................................................................................... 17

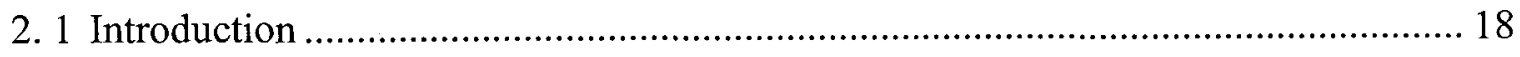

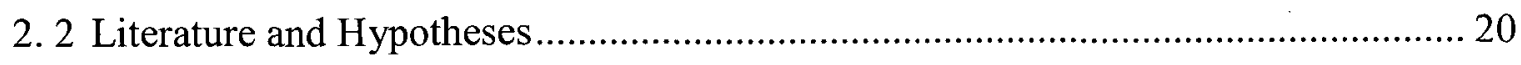

2.2.1 The Stage Model on the Internationalization Process of Firms....................... 20 
2.2.2 The Theory of International New Ventures............................................ 21

2.2.3 New Trade Theory with Heterogeneous Firms ........................................ 23

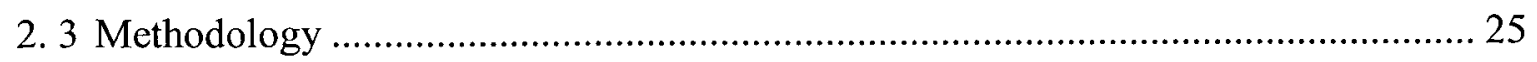

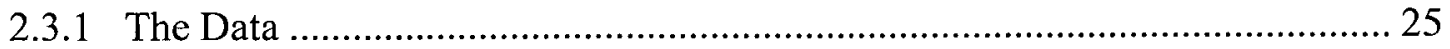

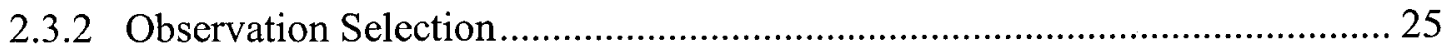

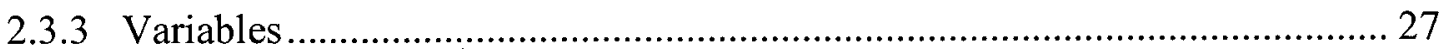

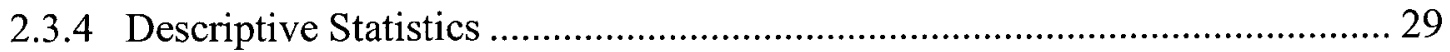

2.3.5 Multinomial Logit Analysis............................................................. 30

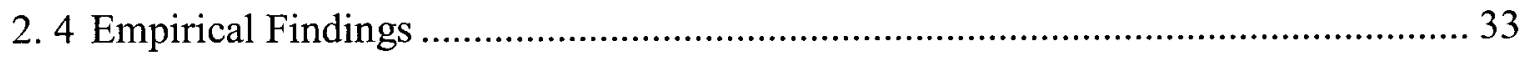

2.4.1 Time Trends in the Number of Canadian Exporters that Export to Different

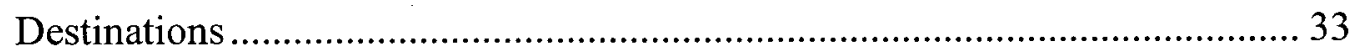

2.4.2 Results of the Multinomial Logit Regressions .......................................... 35

2.4.3 Assessment of Diagnostics and Robustness Test ..................................... 42

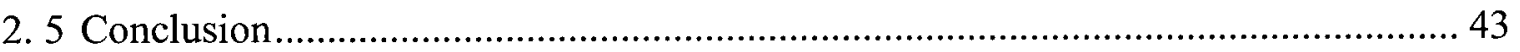

Chapter 3 Born Global, Gradual Global, and their Determinants of Exit from

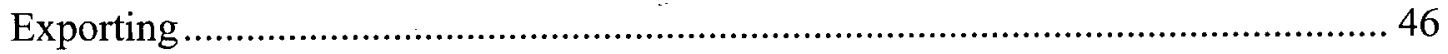

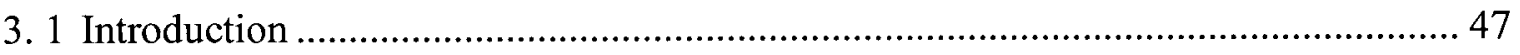

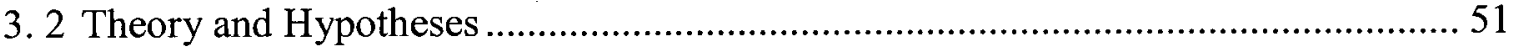

3.2.1 The Effect of Born Global Process on the Survival of New Exporters .......... 52

3.2.2 Exit from Exporting of Born Global and Gradual Global Firms................... 55

3. 3 Data 58

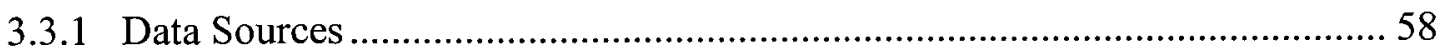

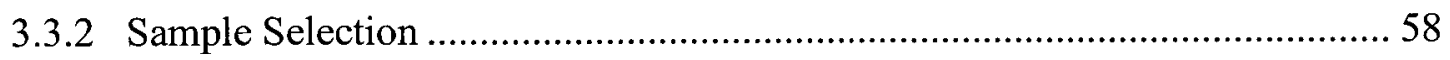

3.3.3 Construction of the Variables of Interest.................................................. 59

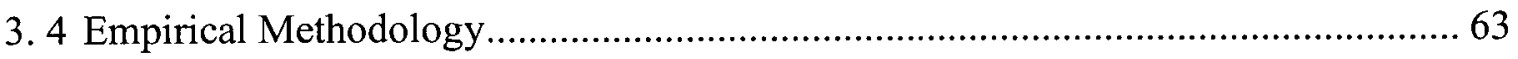

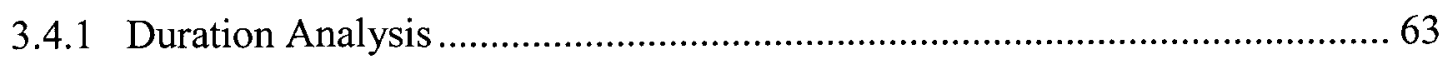

3.4.2 Counting Process Approach for Multiple Failure Events...........................6 65

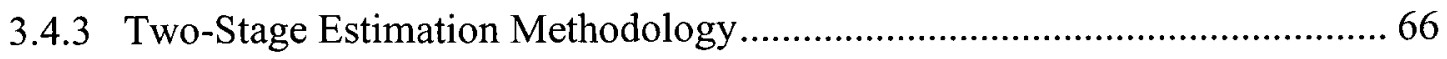

3.4.4 Split-Sample Instrumental Variable Estimation ..................................... 70

3.4.5 Separated Hazard Function for Born Globals and Gradual Globals .............. 71

3. 5 Results 72 


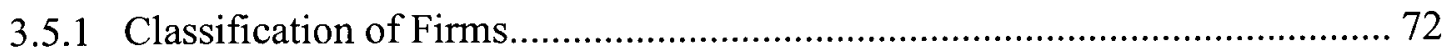

3.5.2 The Characteristics of Born Global and Gradual Global Firms at their

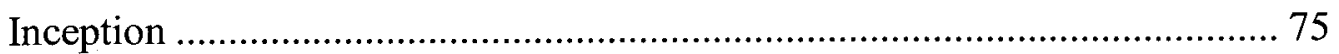

3.5.3 The Effect of Born Global Process on the Exit of New Exporters.................. 78

3.5.4 Exit from Exporting of Born Global and Gradual Global Firms..................... 82

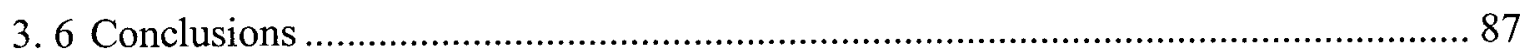

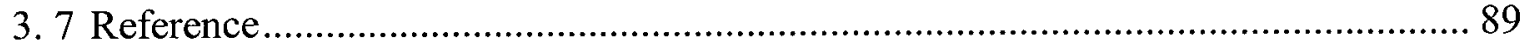

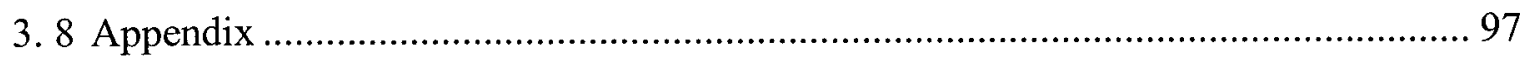

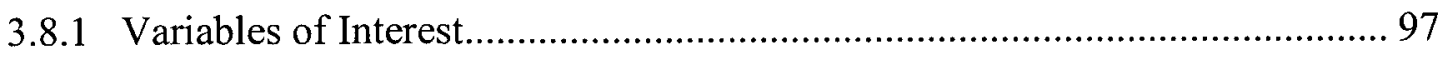

3.8.2 Characteristics of firms that are grouped by export start-up age and initial

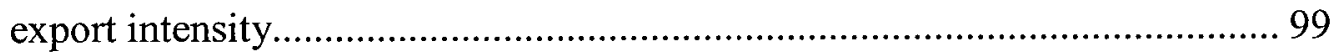

3.8.3 Probit Regression Results......................................................................... 102

3.8.4 Cox proportional Hazard Regression Results............................................... 104

Chapter 4 Conclusion ................................................................................. 109 


\section{List of Tables}

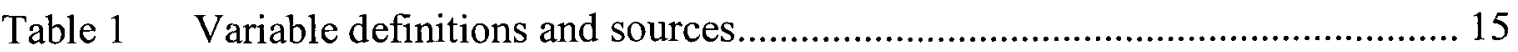

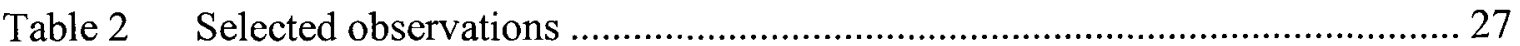

Table 3 Descriptive statistics about Canadian exporting enterprises, by expansion

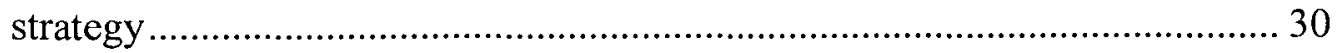

Table 4 Multinomial Logit Regression Results (Observations: 3,257) .................... 35

Table $5 \quad$ Likelihood-ratio test of coefficients .................................................... 43

Table 6 Comparison of the initial conditions between Born Global and Gradual Global

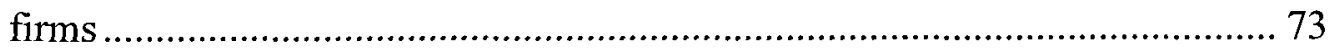

Table 7 Probit regression results: What becomes of Born Global? .......................... 75

Table 8 The effect of Born Global process on the export market survivability of new exporters: regression results from the Cox proportional hazard model......... 80

Table 9 The determinants of exit from exporting: Born Globals and Gradual Globals ..

Table $10 \quad$ Variable definitions, Descriptive statistics, and Sources ........................ 97

Table 11 Matrix of firms that are decomposed by export start-up age and initial export intensity

Table 12 Estimating the Born Global strategy choice 102

Table 13 The determinants of new exporter exit from exporting 104 


\section{List of Figures}

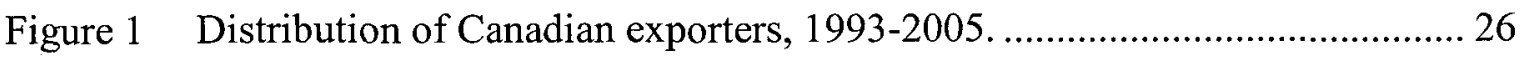

Figure 2 Number of Canadian exporting enterprises, grouped by export destinations. 34

Figure 3 Canadian exporters who exported to emerging markets. .......................... 34

Figure 4 Predicted probability in relation to the year a firm starts to export............... 40

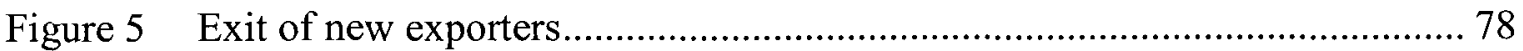




\section{Chapter 1 Data Set Documentation}

\section{1 Introduction}

Recent research in international trade and international business is increasing focused on the role of firm heterogeneity. There is a need for firm-level evidence on the impact of globalization upon Canadian firms. The main focus of my research is to investigate the characteristics and export market survival of Canadian exporters in relation to their internationalization process. I have the good fortune of having access to large-scale administrative databases at Statistics Canada under the Tom Symons Research Fellowship (2006-2007). The unique longitudinal (1993-2005) firm-level data set used in my essays is built upon the following databases: the Exporter Register (1993-2005), the Business Register (1997-2005), and the Longitudinal Employment Analysis Program (LEAP) (1997-2004).

This data set includes information about the international trade activities of all Canadian firms that made at least one shipment to a foreign market between 1993 and 2005 . Specifically, it provides annual information documenting a Canadian exporter's value of exports, export destinations, products exported, employment level, revenues, wages, age, country-of-control, location, and industry. This is the first time such a data set has been constructed for research purposes. Some similar data sets are available in American (Bernard \& Jensen, 1999), French (Eaton et al., 2005), the British (Harris \& Li, 2007), and Colombian (Eaton et al., 2007) firms.

The purpose of this documentation is to facilitate effective checking and updating of this data set and to ensure that other researchers will be able to construct the same data set. 
Good documentation reduces the likelihood of incorrect use of the data. It can also help the author return to the data set for further analysis at some stage in the future.

In the next section I describe the databases that are utilized in this study. Then, I describe the process I used to link different databases in section 3. Section 4 presents definitions and summary statistics of the variables I constructed. The last section talks about error detection and imputation methods.

\subsection{Data Sources}

This data set was constructed by merging three administrative databases. Export information came from the Exporter Register, which is lined to revenue and country of control information from the Business Register. Employment information came from the Longitudinal Employment Analysis Program. In each database, firms are identified by a unique and time-invariant identification number (id). I will discuss the aggregation of the databases in detail in later sections.

\subsubsection{The Exporter Register}

The main data source, the Exporter Register (ER), is a large-scale administrative database of all merchandise trade transactions by Canadian firms at both the establishment and enterprise level from 1993 to 2005 . The data was obtained from two sources: the U.S. Customs documents and the Canada Revenue Agency (CRA) documents. ER is produced and maintained by the International Trade Division at Statistics Canada. Each transaction is recorded separately in ER. A transaction record includes the firm's identification number, a product code that is classified at an eight-digit Harmonized Schedule (HS8), the value of the transaction in Canadian dollars, and the country of destination. If the 
country of destination is the U.S., information on the destination state is also recorded. I aggregated transactions by a given firm to obtain its total value of exports, its number of export destinations, and the variety of products it exports in each year between 1993 and 2005.

The ER database also provides information with regards to the industry to which a firm is classified by a six-digit North American Industry Classification System (NAICS6) code and the province in which a firm is located. This data set allows me to track the entry and exit of firms in the foreign markets, the number of years a firm exported, its value of exports, and the destinations and the products it exports in each year between 1993 and 2005.

Specifically, ER contains a set of annual databases each of which covers different aspects of the export activity of Canadian exporters. The major databases are Est30K and Master_Raw.

The most commonly used database, the Est30K, contains only those establishments that have exported at least $\$ 30,000$ during the research period. Each observation corresponds to a unique year-establishment-enterprise-destination (10 destination groups)-value (value of exports) combination. Each observation in the annual Est $30 \mathrm{~K}$ file includes an identifier that corresponds to the establishment (Estab), an identifier that corresponds to the parent enterprise of the establishment (Entrp), the destination of export (TCCty), and the value of exports (nominal Canadian dollars). Destination of export is grouped into the five U.S. regions and five country groups ${ }^{1}$. The five U.S. regions are: United States

\footnotetext{
${ }^{\text {I }}$ For a complete list of U.S. region and country groupings, please see table 4.8 (page 27) of "A Profile of Canadian Exporters, 1993-2005".
} 
Eastern Seaboard (USE), United States Industrial Heartland (USH), United States Midwest (USM), United States South (USS), and United States West (USW). The five country groups are Mexico (MEX), South America (SA), European Union (EU), Japan $(\mathrm{JPN})$, and Other $(\mathrm{OTH})$. In addition to above information, Est30K provides information on each establishment's census metro area (CMA), number of employees (Empnum), size $\operatorname{class}^{2}$ (Size), location (province of residence) and industry (six-digit NAICS ${ }^{3}$ ).

Another commonly used database, Master_Raw, contains all exporters as long as their total value of exports is non-negative. For each transaction, I observe the shipment year, the eight-digit Harmonized System (HS8) classification ${ }^{4}$, the identifier that corresponds to the establishment (Estab), the identifier that corresponds to the parent enterprise of the establishment (Entrp), the destination country, the destination state if the destination country is the U.S., the (nominal) value shipped, the product's province of origin, and mode of transport (MOT). While an establishment is located in a specified province, it could export commodities that are produced in different provinces (A Profile of Canadian Exporters, 1993-2005). The Master_Raw database also contains all unlinked data. Unlinked data in this database is characterized by the records where the enterprise and establishment fields are blank.

Other databases that are also available in ER are Estab, Estabint, and EstabLib. More specifically, Estab has the same structure as Est30K. However, it contains all exporters as long as their total value of exports is non-negative. Estabint has the same structure as

\footnotetext{
${ }^{2}$ For detailed size class groupings, please see table 4.3 (page 23) of "A Profile of Canadian Exporters, 1993-2005".

${ }^{3}$ NAICS refers to the North American Industry Classification System, which is an industry classification system developed by the statistical agencies of Canada, Mexico and the United States.

${ }^{4}$ Detailed information about the Harmonized System classification can be found in Jiang (2007).
} 
Estab. Furthermore, it contains country and State level detail for destination of export variable. Lastly, EstabLib is a cumulative file which contains the name and address of each establishment and its corresponding parent enterprise that is listed on the ER regardless of the years in which it exported.

\subsubsection{The Business Register}

The second data source, the Business Register (BR), is a mainframe that includes essentially all businesses operating within Canada from 1987 to 2006, including foreign businesses that have links with Canadian companies. The BR is maintained by the Business Register Division (BRD) at Statistics Canada. It contains a complete, up-to-date and unduplicated list of businesses that have a corporate income tax (T2) account, are an employer, or have a GST account. I used the BR database as supplements for the ER database for information on firms' annual revenue (1997-2005), country of control, and first year of business.

\subsubsection{The Longitudinal Employment Analysis Program}

The third data source, the Longitudinal Employment Analysis Program (LEAP), contains employment and payroll information for each employer business in Canada and is available at the enterprise level. LEAP does not cover businesses that are self employed or businesses comprised solely of individuals that do not draw a. This database is maintained by the Science, Innovation and Electronic Information Division (SIEID) at Statistics Canada. The information is available for the years 1997 to 2004 .

In this database, each observation corresponds to a unique combination of yearenterprise-province-Payroll-ILU (individual labour units)-ALU (average labour units). If 
an enterprise has plants that are located in different provinces, its corresponding information is available at the provincial level. The variable 'ILU' measures the labor units an enterprise hired in each province in a given year. In most cases, an ILU represents one employee, but in cases where one person works for several companies in a year, his or her ILU is distributed proportionally among the enterprises. A part-time worker would still contribute one ILU to the total if he or she did not work for another enterprise. The variable 'Payroll' (payroll expenditure) measures the total payroll each enterprise paid in each province in a given year. The variable 'ALU' is equal to the payroll divided by the average salary for a particular industry (at the NAICS six digit level) for a particular provinces.

\section{3 Data Linkage}

In principle, the data set could be constructed at either the enterprise level or the establishment level ${ }^{6}$. Neither basis of construction is unequivocally superior to the other. Each has its own strengths and weaknesses. For example, because enterprises are likely to have establishments that are located in different provinces, establishment-level data are best suited for geographical related analysis. However, enterprise is only the statistical unit $^{7}$ used in the LEAP database. Therefore, this data set is constructed at the enterprise level. Any reference made to "exporter" or "firm" in this study represents a "statistical enterprise".

\footnotetext{
${ }^{5}$ For detailed information on the variable 'ALU', see Baggs (2005), Bagges et al (2009), and Huynh (forthcoming).

${ }^{6}$ An enterprise may have more than one establishment. For more detailed scandalized classification of both enterprise and establishment, please see Page 8 of "A Profile of Canadian Exporters, 1993-2005".

${ }^{7}$ Statistical units are the entities for which information is sought and for which statistics are ultimately compiled (OECD).
} 
A unique and static identification number (id) is assigned to each firm in each database used in this study. Using this firm id as a time-invariant identifier, I linked the original annual ER database and built a panel that covers the period between 1993 and 2005. The LEAP panel covers the period between 1997 and 2004 and the BR panel covers the period between 1997 and 2005. I linked these three panels and built the final data set used in this study. As such, the creation of the analysis data set involved the aggregation of establishment-level data to the enterprise $\operatorname{evel}^{8}$, the aggregation of annual data to panel data in the ER database, the aggregation across the provinces in the LEAP database, and the merging of different databases. I will discuss each step in detail in the following sections.

\subsubsection{Aggregation across Establishments in the ER Database}

The ER database I used to build my data set contains all exporters as long as their total value of exports is non-negative. Many of these exporters are unincorporated businesses, individuals, or institutions whose export behaviors are very irregular. Therefore, I exclude from my data set exporters whose total value of export is less than $\$ 2,000$ in a given year. The reason I used $\mathrm{C} \$ 2,000$ as a threshold is that Canada Revenue Agency (CRA) does not require reports of export transactions that are valued at less than $\mathrm{C} \$ 2,000$ to non-U.S. destinations. Using the Master_Raw database, I aggregate transactions by a given firm to track a firm's entry and exit into and out of the export market, the number of years it exported, its number of establishments that export, its total value of exports, the number of export destinations, and the variety of products exported each year. Using Estab database, I aggregated transactions by a given firm to obtain its total value of

\footnotetext{
${ }^{8}$ An enterprise may have more than one establishment. For more detailed scandalized classification of both enterprise and establishment, please see Page 8 of "A Profile of Canadian Exporters, 1993-2005".
} 
exports, value of exports to the U.S. market, and value of exports to non-U.S. markets. I used the annual Merchandise exports customs-based price indexes to deflate the value of exports. The base year is 2000 . Information of industry and province of residence is available at the establishment level. For an enterprise that has more than one establishment, its industry and province of residence is represented by the establishment that contributed for the highest value of exports. The unique identification number (Entrp) assigned to each firm does not change over time. Using this firm ID as a timeinvariant identifier, I linked the original annual database of the ER over time to build a longitudinal data set. While the number of exporters appearing in the annual ER database varies from 26,478 in 1993 to 40,976 in 2005 , this longitudinal ER database contains 113,111 Canadian enterprises which at some point exported to foreign markets in the research period.

\subsubsection{Aggregation across Provinces in the LEAP Database}

I aggregated the employment and payroll information by a given firm across provinces to obtain its number of employees and payroll expenditure. I used ILU, the individual labour unit, to estimate the number of employees at a given firm. As aforementioned, in cases where one person works for several companies in a year, his or her ILU is distributed proportionally among the enterprises. Therefore, the number of employees of a given firm is not necessarily to be an integer.

\subsubsection{Merging the ER, the BR and the LEAP Databases}

Using the unique identification number assigned to each enterprise, I linked the ER, BR, and LEAP databases. The initial data set of ER contains 113,111 enterprises across all industries that have at least one shipment to any foreign market between 1993 and 2005 . 
Among the 113,111 enterprises that appear in the initial ER data set, $62,462(55.22 \%)$ enterprises appear in the BR database. Among the 113,111 enterprises that appear in the initial ER data set, $43,700(38.63 \%)$ of them appear in the LEAP database. A total of $26,659(22.60 \%)$ observations are available in all three databases.

\section{4 Construction of the Variables of Interest}

Table 1 presents definitions and sources for the data that are used in this study. From the ER database, the variable 'Exports' is measured in millions of Canadian dollars from the ER database and is deflated by annual merchandise exports customs-based price indexes, using base year 2000. From the BR database, the variable 'Revenue' is measured in millions of Canadian dollars from the BR database and is deflated by annual industry price indexes, using base year 2000. This variable is available annually from 1997 to 2005. The variable 'Country of Control' indicates the country of residence of the ultimate shareholder or group of shareholders for a firm. From the LEAP database, I have access to a firm's annual payroll and employment information in each province from 1997 to 2004. 'Employees' indicates the total units of labor a firm hired. 'Payroll' indicates the total business payroll a firm paid.

From the ER database, I can identify the products a firm exported to each destination in each year between 1993 and 2005. In particular, 'HS8' indicates the eight-digit Harmonized Description and Coding System commodity code for the products an enterprise exported. The variable 'Products' refers to the variety of products a firm exported based on the count of its HS8 code from the ER database. This is used as a proxy for a firm's degree of product diversification. 'Country' indicates a firm's country 
of export destination. The variable 'Destinations' is measured by the number of countries to which a firm exported. This is used as a proxy for a firm's degree of destination diversification. 'State' indicates a firm's state of export destination if the.U.S. is its export destination. Furthermore, I generated a dummy variable 'U.S. first', which was set at one if a firm exports to the U.S. before it exports to another country.

The following variables contain information regarding the business and export history of the firm. Because the data is unavailable for the actual year in which a firm was established, Business Register Birth Year is estimated as a proxy for the first year a firm began its business as in Huynh et al. (forthcoming). Specifically, the variable 'BRBY', Business Register Birth Year, is estimated by the first year a firm appeared in the BR database. $28.27 \%$ of enterprises $(17,658$ out of 62,461$)$ were entered into the BR database in 1987, the year the BR database began. Thus, Business Register Birth Year information prior to 1987 is unknown for those firms which entered the BR database in 1987. The variable 'ERBY', Exporter Register Birth Year, is estimated by the first year a firm registered in the ER database, which is used as a proxy for the year a firm began to export. $23.41 \%(26,478$ out of 113,111$)$ enterprises entered the ER database in 1993, the first year the ER database began. Thus, Exporter Register Birth Year information prior to 1993 is unknown for those firms which entered the ER database in 1993.

The following variables contain information on the industry of the firm. 'NAICS6' is a firm's six-digit North American Industrial Classification System industry code. Based on a firm's corresponding two-digit NAICS code from the ER database, I generated a set of dummy variables, 'Industry', which equal one if a firm belongs to a particular industry. There are eleven industry groups in this study. 'ICT' is a dummy variable which equals 
one if a firm belongs to the information and communication technology (ICT) sector. More specifically, the construction of the 'ICT' variable is based on a firm's corresponding NAICS code from the ER database and a classification developed by Statistics Canada and Industry Canada.

The following variables contain information on the location of the firm. Based on a firm's corresponding two-digit province-of-location categorical variable from the ER database, I generated a set of dummy variables 'Province', which equal one if a firm is located in a particular province. If a firm has plants in multiple provinces, I used the province in which the firm derives the highest share of its value of exports as its province of location. If an enterprise has more than one establishment, it is categorized as a 'Multiestablishment' enterprise. The rest of the enterprises are categorized as singleestablishment enterprises. If an enterprise has establishments that are located in different provinces, it is categorized as a 'Multi-province' enterprise. The rest of the enterprises are categorized as single-province enterprises.

In order to indicate from which of the three databases information has been linked, the variable 'Linkage Indicator' is generated. The first character of the variable 'Linkage Indicator' corresponds to the ER database; the second character of the variable corresponds to the BR database; and the third character of the variable corresponds to the LEAP database. A value of " 1 " indicates that information is available from the corresponding database, and a value of " 0 " indicates that information is not available from the corresponding database. 
The following generated variables are calculated using the firm information.

Firm $i$ 's export start-up age, 'ExAge', is measured by the difference between a firm's ER Birth Year and BR Birth Year plus one. For example, if a firm enters the BR database and the ER database in the same year, its start-up age equals to one.

$$
\text { ExAge }_{i}=E R B Y_{i}-B R B Y_{i}+1
$$

Firm $i$ 's export intensity at time $t$, 'EI', is measured as the ratio of export sales to revenue and is available annually from 1997 to 2005 .

$$
E I_{i t}=\frac{\text { Exports }_{i t}}{\text { Revenue }_{i t}}
$$

The variable 'Wage' is calculated by the ratio of total payroll to the number of workers of firm $i$ at time $t$ and is available annually from 1997 to 2004. It is measured in thousands of Canadian dollars and is deflated by annual consumer price indexes, using base year 2000.

$$
\text { Wage }_{i t}=\frac{\text { Payroll }_{i t}}{\text { Employees }_{i t}}
$$

The variable 'Labor Productivity' is calculated by the ratio of revenue to the number of workers of firm $i$ at time $t$ and is available annually from 1997 to 2004. It is measured in thousands of Canadian dollars and is deflated by annual industry price indexes, using base year 2000 .

Labor Productivity $_{i t}=\frac{\text { Revenue }_{i t}}{\text { Employees }_{i t}}$ 


\subsection{Error Detection and Imputation}

The above data set is carefully edited for completeness, consistency and accuracy both manually and using computer-editing procedures. I found that some firms have a higher level of exports than revenue. There could be a time discrepancy between when a firm reports its revenue and when it reports its exports. This is referred to as a calendar issue. Another possibility is that the value of exports or the value of revenue could be incorrectly entered. I compared the regression results with the following specifications: (1) exclude firms that have a higher level of exports than revenue; (2) include firms that have a higher level of exports than revenue, and set the export intensity of such enterprise equal to one. Since the two regressions gave similar results, I set the export intensity of firms that have a higher level of exports than revenue equal to one.

An exporter may register in the ER database but not in the BR database. Such exporters are usually individuals who have to register the ER database because they need to ship products to a foreign buyer. They do not have to register in the BR database unless they want to form a company. An exporter may also register in the ER database before it registers in the BR database. It is possible that firms that start exporting by the end of the year did not get their BR number assigned until the following year (calendar issue). Therefore, for those firms that entered the ER database a maximum of two years before they enter the BR database, I set their start-up age as one. Exporters that entered the ER database a minimum of three years before they entered the BR database are not considered firms until they entered the BR database. As such, their export start-up age should also be one and their ER birth year should be replaced by their BR birth year. 
The method of trend imputation is applied in constructing my data set. For example, for an enterprise whose employment information is available between 1997 and 2004, but is not available in 2005 , I impute from the previous year information with a year-to-year change ratio where there are indications that the enterprises have activity in 2005 .

\subsection{Conclusion}

The firm-level data used in this thesis was created through the merging of three administrative databases: firm-level export transaction information form the Exporter Registry is linked to the Business Registry database for the information about firms' country of control, Business Register birth year, and revenue, and to the LEAP database to obtain data regarding firms' number of employees and payroll expenditures. All of these databases are maintained by Statistics Canada. The creation of the analysis data set involved the aggregation of annual data to panel data, the merging of different databases, the Identification of missing values and errors, the detection of outliers, the selection of desired sample, and the construction of variables of interest.

While this data includes detailed information on export, it does not provide information on import, trade in services, or foreign direct investment. Therefore, it does not necessarily reflect the reality of globally integrated activities of Canadian firms. For my further research, I would like to link this data set to data on imports, trade in services, foreign direct investments, research and development, financial performance, and other attributes regarding Canadian firm's international organization of production. 


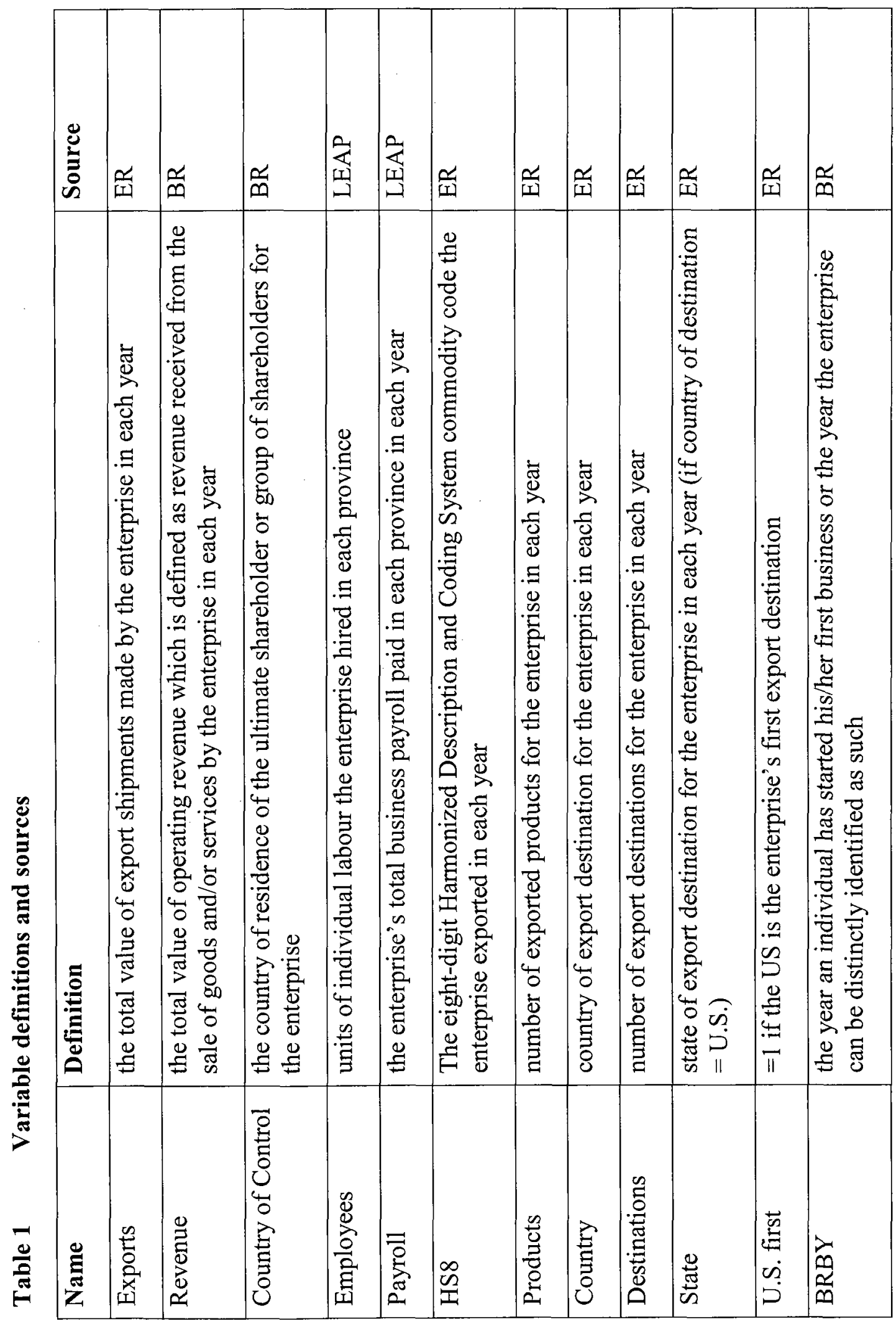




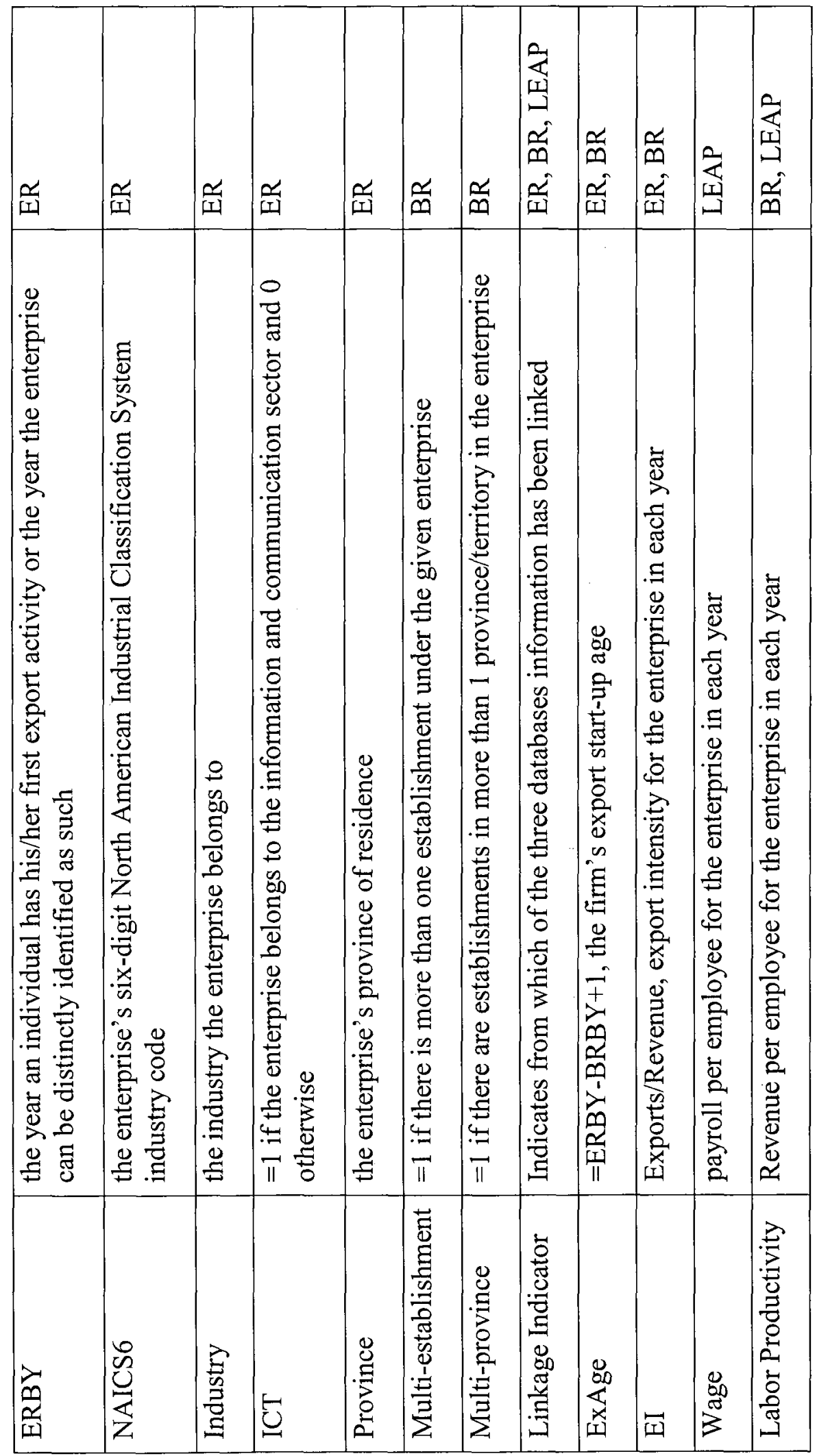




\title{
Chapter 2 A Multinomial Logit Analysis of Foreign Market Expansion of Canadian Exporters
}

(with Zhihao Yu)

\begin{abstract}
This paper investigates the dynamics of the sequential expansion of Canadian exporters into different foreign markets, and how the characteristics of firms affect their choice of different geographical expansion strategies. Almost $70 \%$ of Canadian exporters chose the U.S. as their first export destination between the period of 1993 and 2005. This result supports the prediction of the stage model that Canadian firms export to the U.S. before they export to the rest of the world. The probability for a new exporter to adopt alternative expansion patterns, such as a focus on non-U.S. markets as their first export destination, or exporting to both the U.S. and non-U.S. markets simultaneously has increased dramatically over time. This evidence suggests that the traditional stage internationalization process is not universal to all firms. Moreover, there is a considerable and growing minority of firms that violate the stage model. These findings are invaluable for the creation and development of effective trade and investment promotion policies.
\end{abstract}




\section{1 Introduction}

As Canada's share of exports to the U.S. rose following the 1988 Free Trade Agreement, policy makers and pundits worried that Canadian firms were "putting all their eggs in one basket". This concern formed the basis for policy efforts to diversify Canadian trade such as new Regional Trade Agreements and Team Canada trade missions, echoing the Trudeau Government's "Third Option" policy of widening commercial relations in the previous decade. Meanwhile, a considerable number of studies (e.g., Beaulieu and Emery, 2006; Head, 2007) about Canadian exporters have pointed out their lack of competitiveness in the global market, especially in those fast-growing emerging markets such as China, South Korea, India, Russia, and Brazil.

Canadian exporters lack competitiveness in the global market in at least two senses. First, compared to their foreign-controlled counterparts, Canadian-controlled enterprises export to a narrow range of destinations, with the U.S. being the "natural export destination" (Byrd, 2005). Second, among OECD countries, Canada's exports were the second-least diversified in terms of destinations in 2005, behind only Mexico ("Canada's State of Trade", 2007).

The aim of this study is to explore the economic basis for such concerns by investigating the relevance of the U.S. market to Canadian exporters during their foreign market expansion. It is considered that an exporter's choice of geographic expansion pattern reflects its observation of market conditions by taking into account its own firm level characteristics, and thus, can be viewed as a strategic action. There are three types of foreign market expansion patterns that this study investigates. The first pattern, "U.S. 
first", refers to those firms that export to the U.S. before expanding into any other foreign markets. The second pattern, "non-U.S. first", refers to firms that export to a country other than the U.S. before exporting to the U.S.. Lastly, the third pattern, "simultaneous", refers to firms that export simultaneously to both the U.S. and other markets.

A multinomial logit $\operatorname{model}^{9}$ is employed to analyze how the characteristics of firms affect their choice of different foreign market expansion patterns: "U.S. first", "non-U.S. first", and "simultaneous". Compared to other statistical methods (such as ANOVA analysis, chi-squared analysis, correlation analysis, cluster analysis, etc.), this method has many advantages. For example, using the estimates from the multinomial logit model, one can predict a firm's probability of choosing different foreign market expansion patterns based on its characteristics. Therefore, the results of this study are able to provide new insights on the foreign market expansion pattern of firms.

A unique longitudinal (1993-2005) firm-level data set is employed to investigate foreign market expansion patterns of a relatively large sample $(3,257)$ of Canadian exporters. This data set is drawn from three large scale administrative databases from Statistics Canada: the Exporter Register, the Business Register, and the Longitudinal Employment Analysis Program (LEAP). It includes business activities of all Canadian exporting enterprises which had at least one shipment to a foreign country between 1993 and 2005 . Therefore, this study is able to investigate the foreign market expansion strategy of firms in dynamic settings without having sample selection issues.

\footnotetext{
${ }^{9}$ For studies using the multinomial-logit approach in the IB literature, see recent work by Benito, Pedersen, and Peterson (2005), and Wei, Liu, and Liu (2005).
} 
The rest of this paper begins with a review of the relevant literature and the hypotheses to be tested in section 2 . Section 3 explains the methodology utilized in this study. Section 4 presents empirical results with discussions. Finally, concluding remarks are discussed in section 5 .

\section{2 Literature and Hypotheses}

\subsubsection{The Stage Model on the Internationalization Process of Firms}

According to traditional theories of internationalization--the stage model ${ }^{10}$, the internationalization of firms is "a process in which the enterprise gradually increases its international involvement" (Johanson and Vahlne, 1990). Presumably, after accumulating experience in the domestic market, firms often export first to a single neighboring market and then subsequently enter more distanced foreign markets (Bell, 1995). The argument of the stage model is that firms have limited knowledge, high risk aversion, and high perceived uncertainty about foreign markets (Madsen and Servais, 1997). They choose to become internationalized slowly and incrementally in order to gain experience from one market to aid entry into the next. This reduces uncertainty and risk over time for each market and build up sufficient capacity in selling the product in the global market over time.

A considerable number of empirical studies have found evidence that supports the stage model. In their study of four Swedish firms, Johanson and Wiedersheim-Paul (1975) concluded that internationalization is a gradual process and firms commit slowly in order

\footnotetext{
${ }^{10}$ The stage model, or the Uppsala model, is the earliest internationalization model that was developed by a group of Swedish economists (Johanson and Wiedersheim-Paul, 1975; Forsgren and Johanson, 1975) who worked at the Uppsala University.
} 
to accumulate better knowledge about foreign markets. Using the ratio of the value of exports to total sales as an indicator of the level of export involvement, Burton and Schlegelmilch (1987) investigated over 300 firms from the U.K. and West Germany. The results of their study support the idea that internationalization is a gradual process and is a function of organizational characteristics and managerial attitudes.

In the international trade literatures, a study by Eaton et al. (2007) investigated the crossmarket dynamics of Colombian firms from 1996 to 2005. Eaton et al. found that it appears to be a popular geographic expansion strategy for exporters to present themselves gradually from a single neighboring foreign market to additional destinations within the regional market, and then to expand to the larger OECD markets. The results of Eaton et al.'s study further support the idea of the stage model by suggesting that the likelihood of export market survival depends on their initial destination market and success in neighboring markets.

If the stage model is relevant, Canadian firms are expected to choose the "U.S. first" expansion pattern by choosing the U.S. as their first export destination. This argument is the basis for the following hypothesis:

Hypothesis 1: The majority of Canadian exporters follow the "U.S. first" strategy.

\subsubsection{The Theory of International New Ventures}

Beginning in the early 1990s, a number of empirical studies have reported an interesting phenomenon of international new ventures (INVs) that contradicts the traditional stage model. This phenomenon has subsequently raised many interesting questions about the 
internationalization process of firms. An International New Venture (INV) is also referred to as a Born Global, or an International Entrepreneurship, and is conceptualized as "from [its] inception, seeking to derive significant competitive advantage from the use of resources and sale of outputs in multiple countries" (Oviatt and McDougall, 1994).

Previous studies have used macro factors as an explanation of the emergence of INVs. These factors include shrinking transportation and communication costs and "improvements in global telecommunications and transport networks, combined with increasingly liberalized global trading regimes" (Fan and Phan, 2007). According to Madsen and Servais (1997), the INV phenomenon is driven by a set of pre-conditions such as a more harmonized international business environment, advanced technological development in transportation and communication, and increased international experience of the founding entrepreneurs.

If the theory of INVs is relevant, younger Canadian exporters are expected to either pursue a "non-U.S. first" or a "simultaneous" pattern. This argument is the basis for the following hypothesis:

Hypothesis 2: Everything else being equal, the later a Canadian firm starts to export, the lower the probability for it to choose the "U.S. first" relative to other patterns.

The ceteris paribus assumption underlying Hypothesis 2 is particularly important since the characteristics of firms that start their businesses each year might be very different. The multinomial logit model used in this study allows us to overcome such problems by estimating a firm's predicted probability of choosing its expansion strategy based on its characteristics. 
Numerous studies have noted the role of high technology in promoting the emergence of INVs. An early study by Jolly, Alahuhta, and Jeannet (1992) on high-technology startups argued that such firms are associated with high fixed costs and limited resources. Therefore, they are better off by exporting intensely in a single leading market. Furthermore, the importance of physical distance in the market selection is less relevant to these high-technology start-ups. In his study of computer software companies, Bell (1995) questioned the relevance of stage model for high-technology industry. After investigating 70 high-technology new ventures, Shrader (2001) concluded that the prediction of traditional step-by-step internationalization theory is not reflected. These arguments are the basis for the following hypothesis:

Hypothesis 3: Everything else being equal, firms that belong to the hightechnology industry are less likely to choose "U.S. first" relative to other patterns.

\subsubsection{New Trade Theory with Heterogeneous Firms}

In the international trade literature, studies from the microeconometrics of international firm activities found that exporters have a superior performance of relative to nonexporters (e.g. Bernard and Jensen, 1999; Isgut 2001, Clerides, Lach, and Tybout, 1998;

Delgado, Farinas, and Ruano, 2002). For example, firm-level evidence from European countries reveals that internationalized firms are "superstars", they "are bigger, generate higher value added, pay higher wages, employ more capital per worker and more skilled workers, and have higher productivity". (Mayer and Ottaviano, 2007, p11) 
An important theoretical framework to explain such phenomenon is the Melitz (2003) model with firm heterogeneity. The Melitz model is a theoretical model that incorporates firm heterogeneity into the Krugman's (1979) monopolistic competition framework. In that model, there are fixed costs and variable costs associated with entering the export market. Eaton, Kortum, and Kramarz (2008) used a similar technology assumption but allowed the fixed distribution cost to vary across export destinations. Based on Eaton, Kortum, and Kramarz's model, more productive firms should be able to export to more distant destinations and more destinations.

Eaton et al.'s arguments are supported by Ruane and Sutherland (2004)'s study on the characteristics of Irish manufacturers that export to different destinations. In their study, Ruane and Sutherland treated the UK as a local market for Irish firms because of the unique trade relationship between Ireland and the UK. Their results confirmed that exporters who seek to export to non-UK destinations (globally) have superior performance indicators compared to those who export primarily to the UK (locally).

For Canadian firms, there are lower risks and costs associated with entering the U.S. market because of the geographical advantage and similarity between these two countries. As such, exporting to the U.S. can be viewed as simply an expansion of business activities in the domestic market. On the other hand, exporting globally to unfamiliar foreign markets outside the U.S. will expose exporters to greater competitive pressures and demand higher entry costs and productivity requirements. These arguments are the basis for the following hypothesis:

Hypothesis 4: Everything else being equal, more productive firms are less likely to choose the "U.S first" relative to other patterns. 


\section{3 Methodology}

\subsubsection{The Data}

The data we constructed to examine our research questions come from the Exporter Register (ER), the Business Register (BR), and the Longitudinal Employment Analysis Program (LEAP). All these databases are produced and maintained by Statistics Canada. The data set comprises 113,111 Canadian exporters. The details of the data we use and the associated database are provided in chapter 1.

\subsubsection{Observation Selection}

Figure 1 provides an overview of the distribution of the cumulative number of Canadian exporting enterprises, from 1993-2005, with respect to their export destinations and expansion strategies. An exporter who only exported to the U.S. between 1993 and 2005 belongs to the "U.S. only" category; an exporter who has never exported to the U.S. in the same period belongs to the "non-U.S. only" category; an exporter who has at least one shipment to the U.S. and another shipment to a non-U.S. destination in that period belongs to the "both" category.

Figure 1 suggests that Canadian exporters are highly concentrated in the U.S. market. From 1993 to $2005,73,135$ of the 113,111 , or over $65 \%$ Canadian exporting enterprises exported only to the U.S. market. As discussed before, the U.S. is considered as the regional market, and the rest of the foreign markets are considered as the global market for Canadian exporters. Consequently, exporters that belong to the "U.S. only" category are mainly regional-based. Less than $15 \%$ of exporters exported to non-U.S. markets only. About one fifth of Canadian exporters have exported to both the U.S. and non-U.S. markets. These two categories of exporters are relatively global-based. 
Figure 1 Distribution of Canadian exporters, 1993-2005.

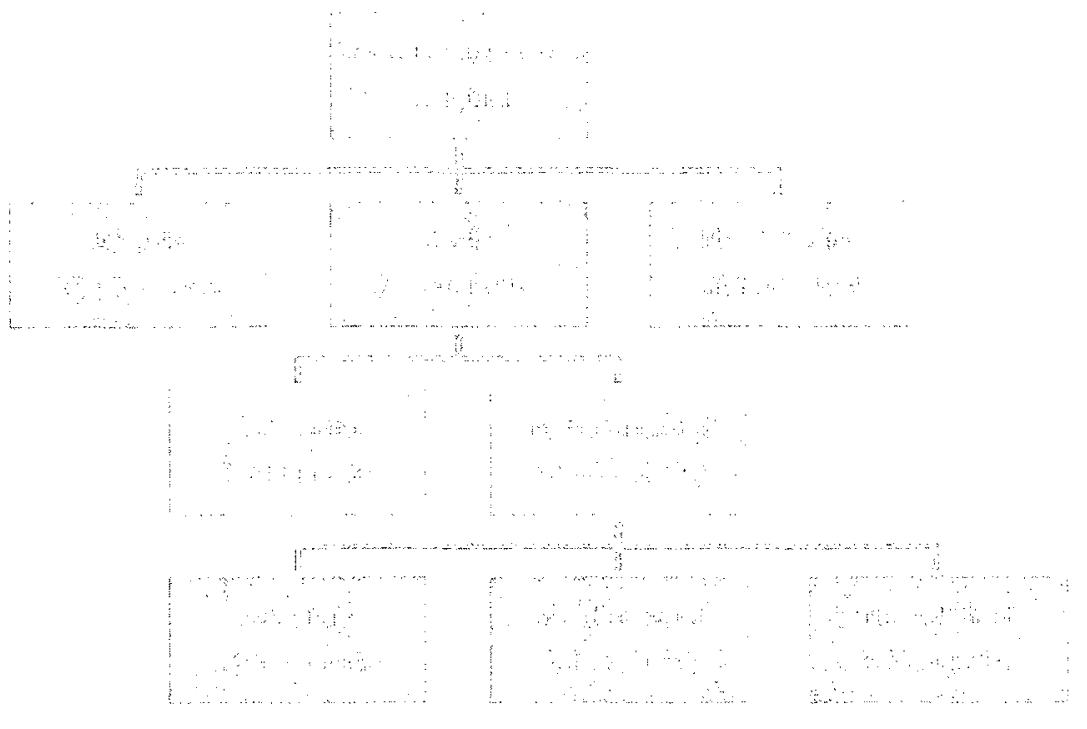

About $12 \%$ of exporters in the "both" category exported to both the U.S. and non-U.S. markets in 1993. Because of the coverage of the ER database, the expansion patterns of these exporters are unobservable. As such, they are treated as truncated observations. The non-truncated observations are grouped according to their sequence of foreign market expansion. The groups are: "U.S. first", "non-U.S. first" and "simultaneous". More than $70 \%$ of exporters chose the U.S. market while less than one fifth of exporters chose nonU.S. markets as their first export destination. Only one tenth of exporters started exporting to both the U.S. and non-U.S. markets simultaneously. The foreign market expansion pattern that is suggested by the stage model, "U.S. first", is thus the most common expansion strategy for Canadian exporters. As such, Hypothesis 1 is supported, since the majority of Canadian exporters have chosen the "U.S. first" pattern.

The intent of this study is to investigate exporters who have expanded their business in the international market successfully over the research period. For this purpose, an 
exporter is selected if it satisfies the following conditions: (1) it has been exporting for over three years; (2) it exported to both the U.S. and non-U.S. destinations in 2005--the last year that our data is available. As shown in Table 2, about $69.32 \%(10,384$ out of 14,979 ) "U.S. first" category exporters, 40.3\% (860 out of 2,122) "simultaneous" category exporters, and 52.25\% (1,752 out of 3,353) "non-U.S. first" category exporters are able to satisfy all three restrictions.

\section{Table 2 Selected observations}

\begin{tabular}{|l|r|r|r|}
\hline Strategy & Total & Selected & Percentage \\
\hline U.S. first & 14,979 & 10,384 & $69.32 \%$ \\
\hline Simultaneous & 3,353 & 1,752 & $52.25 \%$ \\
\hline Non-U.S. first & 2,122 & 860 & $40.53 \%$ \\
\hline Total & 20,454 & 12,996 & $63.54 \%$ \\
\hline
\end{tabular}

\subsubsection{Variables}

The dependent variable, "Pattern" is a categorical variable that includes three outcomes about the foreign market expansion strategy of Canadian exporters: "U.S. first", "nonU.S. first", and "simultaneous".

The following are the independent variables that are included in the multinomial logit analysis. The variable 'BRBY', Business Register Birth Year, is estimated by the first year a firm appeared in the BR database, which is used as a proxy for the first year a firm began its business. The BR database begins in 1987. Thus, information prior to 1987 is unknown for those firms which entered the BR database in 1987. The variable 'ERBY', 
Exporter Register Birth Year, is used as a proxy for the year a firm began to export. It is estimated by the first year a firm registered in the ER database. The ER database begins in 1993. Thus, information prior to 1993 is unknown for those firms which entered the ER database in 1993. Accordingly, a firm's export start-up age, 'ExAge', is measured by the difference between a firm's ER Birth Year and BR Birth Year plus one. For example, if a firm enters the BR database and the ER database in the same year, its start-up age equals to one.

From the LEAP database, I have access to a firm's annual payroll and employment information in each province from 1997 to 2004. 'Employees' indicates the total units of labor a firm hired. The variable 'Wage' is calculated by the ratio of total payroll to the number of workers. This variable is measured in thousands of Canadian dollars.

Based on firm-level data, a study by Rao and Tang (2000) suggest that Canadiancontrolled manufacturing firms were less productive than their foreign-controlled counterparts between 1985 and 1995. Furthermore, an earlier study by Shapiro (1981) suggested that the characteristics of U.S.-controlled and non-U.S. foreign-controlled Canadian firms are very different. Based on a firm's country of control from the BR database, this study categorizes the country-of-control of Canadian exporters as Canadian-controlled, U.S.-controlled, and non-U.S. foreign-controlled.

The variable 'Products' refers to the variety of products a firm exported based on the count of its HS8 code from the ER database. This is used as a proxy for a firm's degree of product diversification. If an enterprise has more than one establishment, it is categorized as a 'Multi-establishment' enterprise. The rest of the enterprises are categorized as singleestablishment enterprises. Based on a firm's corresponding North American Industry 
Classification System (NAICS) code from the ER database, a set of dummy variables "Industry" are generated, which equal one if a firm belongs to a particular industry. There are 23 industry groups in this study. Based on a firm's corresponding two-digit province of location category variable from the ER database, a set of dummy variables "Provinces" are generated, which equal one if a firm is located in a particular province. If a firm has plants in multiple provinces, the province in which the firm derives the highest share of it value of exports is used as its province of location.

\subsubsection{Descriptive Statistics}

Table 3 presents statistics on the means and medians of the selected explanatory variables. The median is a more informative indication than the mean when the distributions are highly skewed. The median is the middle of a distribution that is less sensitive to extreme scores than the mean. If the mean for the data is larger than the median, as in most cases in Table 3, the data distribution is right-skewed. For example, there are fewer large exporters than small exporters in the data since the means for variable "Employee" are much higher than the medians. Examining the mean values, it appears that the "U.S. first" category exporters are the oldest and largest; they started to export the earliest, but offer the lowest wages. "Simultaneous" category exporters are the youngest and the most product-diversified; they started to export the latest, but offer the

highest wages. Finally, exporters in the "non-U.S. first" category are the least product diversified. 
Table 3 Descriptive statistics about Canadian exporting enterprises, by expansion strategy

\begin{tabular}{|c|c|c|c|c|}
\hline Variables & & U.S. first & Simultaneous & Non-U.S. first \\
\hline ExAge & $\begin{array}{l}\text { Mean } \\
\text { Median }\end{array}$ & $\begin{array}{l}15 \\
16\end{array}$ & $\begin{array}{l}11 \\
10\end{array}$ & $\begin{array}{l}13 \\
12\end{array}$ \\
\hline Year & $\begin{array}{l}\text { Mean } \\
\text { Median }\end{array}$ & $\begin{array}{l}\mathbf{1 9 9 5} \\
1993\end{array}$ & $\begin{array}{l}2000 \\
1999\end{array}$ & $\begin{array}{l}1997 \\
1996\end{array}$ \\
\hline Size & $\begin{array}{l}\text { Mean } \\
\text { Median }\end{array}$ & $\begin{array}{l}59 \\
9\end{array}$ & $\begin{array}{l}28 \\
2\end{array}$ & $\begin{array}{l}27 \\
2\end{array}$ \\
\hline Products & $\begin{array}{l}\text { Mean } \\
\text { Median }\end{array}$ & $\begin{array}{l}3.4 \\
2\end{array}$ & $\begin{array}{l}4.1 \\
3\end{array}$ & $\begin{array}{l}2.5 \\
1\end{array}$ \\
\hline Wage & $\begin{array}{l}\text { Mean } \\
\text { Median }\end{array}$ & $\begin{array}{l}35 \\
30\end{array}$ & $\begin{array}{l}\mathbf{3 8} \\
30\end{array}$ & $\begin{array}{l}37 \\
29\end{array}$ \\
\hline
\end{tabular}

Note: Wage is measured in thousands of Canadian dollars.

\subsubsection{Multinomial Logit Analysis}

The dependent variable is a categorical variable that includes different foreign market expansion patterns that have been chosen by Canadian exporters: U.S. first, non-U.S. first, and simultaneous. Because this variable is categorized without implicit order, a multinomial logit model ${ }^{11}$ (MNLM) is more appropriate than an ordered logit model or a nested logit model. Compared to conditional logit models, which consider the effects of choice-specific characteristics on the determinants of choice probabilities, the MNLM

\footnotetext{
11 The multinomial probit model involves solving multiple integrations related to the multivariate normal distribution, thus is computationally difficult in estimation and rarely used.
} 
makes the choice probability dependent on firm-specific characteristics. As a result, the MNLM is more appropriate for the aim of this study.

The probability for the $i_{t h}$ firm $i$ to choose the $j_{t i}$ expansion pattern $\left(P_{i j}\right)$ is given by

$P_{i j}=\operatorname{Pr}\left(U_{i j}>U_{i k}\right)$, for $k \neq j, i=1, \ldots N, j, k=1,2,3$

with $U_{i j}$ being the maximum utility (return) attainable for firm $i$ if the firm chooses the $j_{t h}$ strategy, and

$\left.U_{i j}=x_{i} \beta_{j}+\varepsilon_{i j}\right), \quad i=1, \ldots N, j=1,2,3$

where $x_{i}$ is a set of explanatory variables that might affect a firm's choice on its foreign market expansion pattern, and $\beta_{j}$ is a column vector of unknown parameters (Judge et al., 1985). If the stochastic term $\varepsilon_{i j}$ is a random error that follows a log-Weilbull ${ }^{12}$ distribution, the MNLM can be expressed as

$P_{i j}=\exp \left(x_{i} \beta_{j}\right) / \sum_{j=1}^{j} \exp \left(x_{i} \beta_{j}\right), i=1, \ldots N, j=1,2,3$

The parameters $(\beta)$ are estimated by maximizing a log likelihood function. The probability of firm $i$ to choose an alternative pattern $m$ is

$\operatorname{Pr}\left(y_{i}=m\right)=\exp \left(x_{i} \beta_{m}\right) /\left(1+\sum_{j=1}^{J-1} \exp \left(x_{i} \beta_{i}\right)\right), m=1,2,3$

where for firm $i, y_{i}$ is the value of the outcome variable. $x_{i}$ is the vector of the explanatory variables, and for alternatives $j=1, \ldots, J-1, \beta_{j}$ is the vector of parameters.

\footnotetext{
${ }^{12}$ The $\log$-Weibull distribution, also known as the Gumbel distribution, is a special case of the FisherTippett distribution.
} 
The vector of independent variables $x_{i}$ includes the age of the firm when it starts to export, the year in which it starts to export, its size (number of employees), wages, and the variety of products it exports during the first year of its export activity, its country-ofcontrol, Multi-establishment (a dummy variable which equals to one if a firm has more than one plant), sector specific dummy variables, and province specific dummy variables.

In order to interpret the estimation results more intuitively, this study makes use of the concept of marginal effects on event probability by examining partial derivatives of a response probability with respect to $x_{k}$

Marginal Effect $=\frac{\partial \operatorname{Pr} o b(y=m \mid x)}{\partial X_{k}}=P_{m}\left(\beta_{m k}-\sum_{j=1}^{J-1} P_{j} \beta_{j k}\right)$,

where $P_{m}$ is short for $\operatorname{Pr} o b(y=m \mid x), x_{k}$ is the $k_{t h}$ explanatory variable. As shown in Equation (5), the value of marginal effect depends on the level of all variables in the model. It is often computed with all variables held at their mean or by computing the marginal change for each observation in the sample and then averaging across all values. The marginal effect of a dummy variable on the event probability is for a discrete change from 0 to 1 . Thus, it can only provide a rough approximation for the signs of the effects. A positive sign of a parameter estimate suggests that the likelihood of the event increases with the level of $\mathrm{X}$, holding the other variables constant, and vice versa. Therefore, this study will focus on the interpretation of the quantitative effect of continuous variables and the sign effect of dummy variables. After that, the observed and predicted probabilities for each pattern will be compared, where the value of the predicted 
probability of each outcome is computed by using our fitted logistic model coefficients with the specified set of values for the predictors.

\section{4 Empirical Findings}

\subsubsection{Time Trends in the Number of Canadian Exporters that Export to Different Destinations}

Figure 2 plots the number of firms grouped by different types of destinations to which they exported. The total number of exporters increased from under 44,000 in 2000 to its peak of over 45,000 in 2002, and decreased since then in 2005. The number of exporters who exported to the U.S. market increased slightly from 2000 to 2001, and decreased sharply since then to 2005. The number of exporters who exported to non-U.S. destinations increased constantly from below 11,000 to above 15,000 in 2004 , and then decreased slightly in 2005. The number of exporters who exported to emerging markets increased constantly from about 5,000 in 2000 to 8,000 in 2005 . When indirect trade exists, shipment may be attributed to a country that is not the final destination of goods. For example, a previous study by Bohatyretz and Santarossa (2005) showed that in 2002, Chinese-reported imports from Canada were 1.4 times higher than Canadian-reported exports to China. Therefore, it is possible that the number of exporters to the fast-growing emerging markets may be under estimated. 
Figure 2 Number of Canadian exporting enterprises, grouped by export destinations.
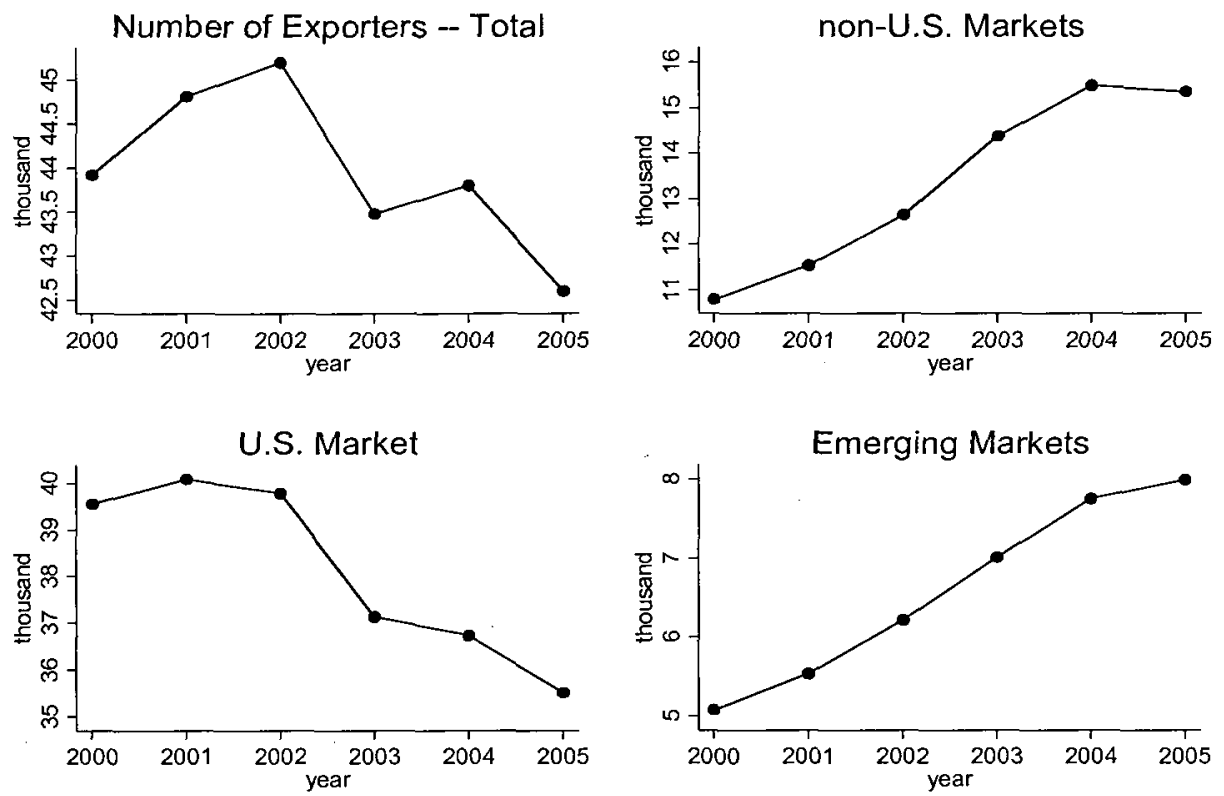

Figure 3 Canadian exporters who exported to emerging markets.
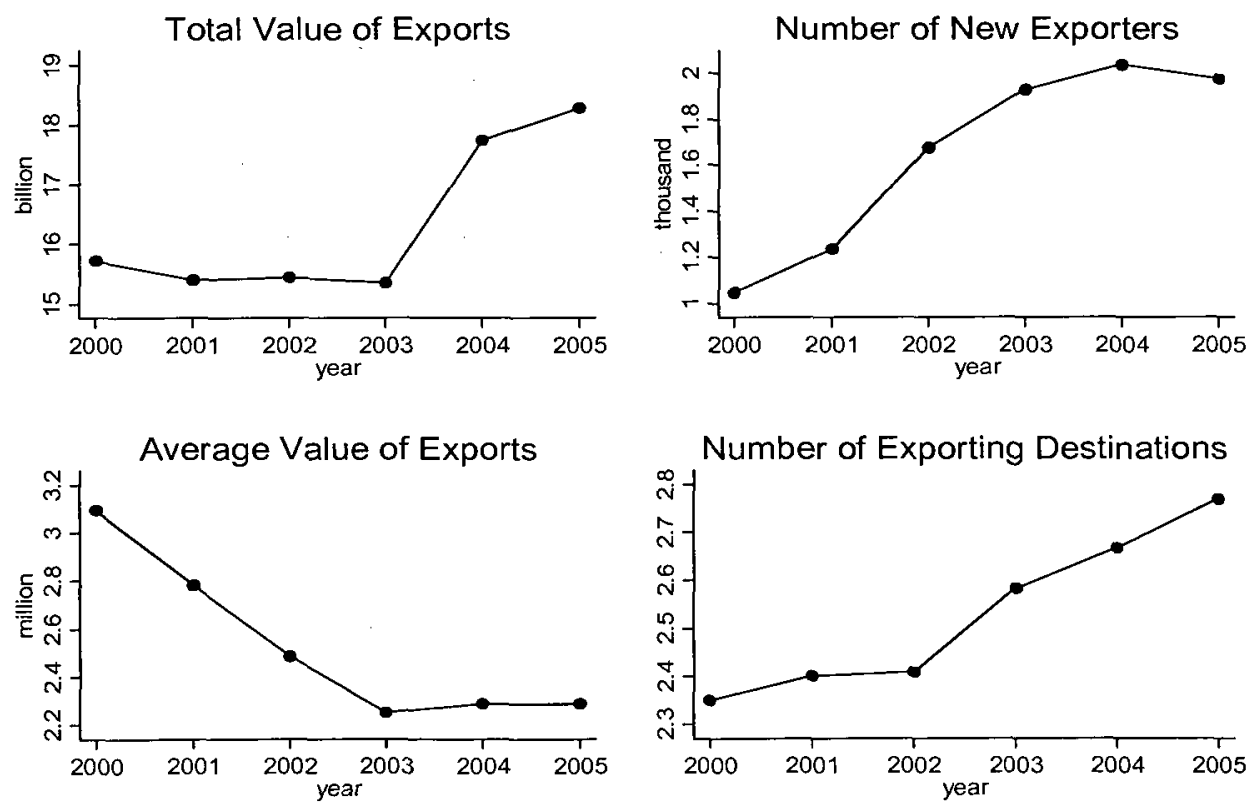

Note: Price index: $2000=100$. 
The numbers of exporters that export to the fast-growing emerging markets are described in Figure 3. The average value of exports decreased but the total value of exports increased remarkably before and after 2003. Both the numbers of new exporters and export destinations posted a remarkable increase between 2003 and 2005. This implies that higher numbers of exporters, especially in the small and medium-sized classes, began exporting to these markets and that Canadian businesses are exporting to a greater number of destinations within the emerging markets.

\subsubsection{Results of the Multinomial Logit Regressions}

Table 4 presents results of the multinomial logit regressions. The diagnostic assessments and the fitness of the model are provided in Table 4. As shown in Table 4, everything else being equal, the later the firm enters the export market, the lower the probability it will choose the "U.S. first" pattern by $1.34 \%$, but increases its probability of choosing the "non-U.S. first" and "simultaneous" pattern by $0.09 \%$ and $1.25 \%$, respectively. This evidence supports Hypothesis 2 that everything else being equal, the later a Canadian firm starts to export, the lower the probability for it to choose the "U.S. first" relative to other patterns.

Table 4

Pattern

Year

Size

Wage
Multinomial Logit Regression Results (Observations: 3,257)

\section{U.S. first Simultaneous Non-U.S. first}

$-0.0134^{c}$

$0.0009^{a}$

$0.0125^{a}$

$(0.0012)$

(0.0001)

0.0001

$-0.0008$

0.0007

(0.0008)

(0.0015)

(0.0012)

$-0.0002$

0.0001 


$\begin{array}{lrrr} & (0.0004) & (0.0001) & (0.0001) \\ \text { Products } & \mathbf{0 . 0 0 8 3 ^ { a }} & \mathbf{0 . 0 0 0 3} & \mathbf{- 0 . 0 0 8 6}^{a} \\ & (0.0015) & (0.0001) & (0.0015) \\ \text { U.S. Controlled } & \mathbf{- 0 . 0 9 4 7 ^ { a }} & \mathbf{0 . 0 0 3 7} & \mathbf{0 . 0 9 0 9 ^ { a }} \\ & (0.0354) & (0.0024) & (0.0353) \\ \text { Non-U.S. foreign } & \mathbf{0 . 0 0 7 5} & \mathbf{- 0 . 0 0 1 2} & \mathbf{- 0 . 0 0 6 3} \\ \text { Controlled } & (0.0214) & (0.0014) & (0.0213) \\ \text { Multi-Establishment } & \mathbf{0 . 0 0 2 2} & \mathbf{- 0 . 0 0 3 5} & \mathbf{0 . 0 0 1 3} \\ & (0.0117) & (0.0005) & (0.0117) \\ \text { ExAge } & \mathbf{0 . 0 0 0 1} & \mathbf{- 0 . 0 0 0 3} & \mathbf{0 . 0 0 0 2} \\ & (0.0007) & (0.0001) & (0.0007)\end{array}$

Industry (reference: Computer and Electronics)

Pattern

Agriculture

Mining, Oil, Gas

\& Utilities

Construction

Wholesale Trade

Retail Trade

Transportation \&

Warehousing

Information

\section{U.S. first} $-0.0306$

$(0.0379)$

$-0.0397$

$(0.0549)$

$-0.1878^{b}$

$(0.0770)$

$-0.0656^{a}$

$(0.0207)$

0.0165

(0.0214)

$-0.0661$

$(0.0536)$

$-0.0115$
Simultaneous

0.0012

(0.0022)

$-0.0002$

$(0.0021)$

$-0.0025^{b}$

(0.0010)

$-0.0004$

$(0.0007)$

$-0.0103^{a}$

(0.0012)

0.0031

$(0.0033)$

$-0.0029^{a}$
Non-U.S. first

0.0294

(0.0376)

0.0399

(0.0547)

$0.1902^{b}$

$(0.0769)$

$0.0661^{a}$

(0.0206)

$-0.0063$

$(0.0214)$

0.0630

$(0.0532)$

0.0144 


\begin{tabular}{|c|c|c|c|}
\hline \& Cultural & $(0.0353)$ & $(0.0007)$ & $(0.0353)$ \\
\hline Finance \& & -0.0455 & $-0.0019^{c}$ & 0.0474 \\
\hline Insurance & $(0.0426)$ & $(0.0010)$ & $(0.0426)$ \\
\hline \multirow[t]{2}{*}{ Business Services } & -0.0163 & $-0.0012^{c}$ & 0.0176 \\
\hline & $(0.0198)$ & $(0.0007)$ & $(0.0198)$ \\
\hline \multirow[t]{2}{*}{ Other Services } & 0.0121 & -0.0015 & -0.0106 \\
\hline & $(0.0228)$ & $(0.0009)$ & $(0.0227)$ \\
\hline \multirow[t]{2}{*}{ Food \& Beverage } & -0.0458 & -0.0014 & 0.0472 \\
\hline & $(0.0319)$ & $(0.0009)$ & $(0.0318)$ \\
\hline \multirow[t]{2}{*}{ Textile, Clothing \& Leather } & -0.0354 & -0.0014 & 0.0368 \\
\hline & $(0.0306)$ & $(0.0009)$ & $(0.0306)$ \\
\hline \multirow[t]{2}{*}{ Wood } & -0.0221 & -0.0017 & 0.0238 \\
\hline & $(0.0364)$ & $(0.0013)$ & $(0.0363)$ \\
\hline \multirow[t]{2}{*}{ Paper } & -0.1084 & -0.0011 & 0.1094 \\
\hline & $(0.0727)$ & $(0.0019)$ & $(0.0726)$ \\
\hline \multirow[t]{2}{*}{ Printing } & $0.0424^{b}$ & $-0.0060^{a}$ & $-0.0365^{c}$ \\
\hline & $(0.0202)$ & $(0.0007)$ & $(0.0202)$ \\
\hline \multirow[t]{2}{*}{ Petroleum \& Chemical } & -0.0287 & 0.0004 & 0.0283 \\
\hline & $(0.0267)$ & $(0.0013)$ & $(0.0266)$ \\
\hline \multirow[t]{2}{*}{ Plastic \& Rubber } & -0.0197 & 0.0004 & 0.0193 \\
\hline & $(0.0259)$ & $(0.0013)$ & $(0.0258)$ \\
\hline \multirow[t]{2}{*}{ Non-Metallic Mineral } & $0.0574^{a}$ & $-0.0064^{a}$ & $-0.0510^{a}$ \\
\hline & $(0.0139)$ & $(0.0007)$ & $(0.0139)$ \\
\hline \multirow[t]{2}{*}{ Metal } & -0.0006 & $-0.0018^{b}$ & 0.0024 \\
\hline & $(0.0185)$ & $(0.0007)$ & $(0.0184)$ \\
\hline Machinery & 0.0168 & $-0.0016^{b}$ & -0.0152 \\
\hline
\end{tabular}




\begin{tabular}{lccr} 
& $(0.0156)$ & $(0.0007)$ & $(0.0156)$ \\
Transportation Equipment & $\mathbf{0 . 0 3 2 5}$ & & \\
& 0.0170 & $0.0021^{a}$ & $\mathbf{0 . 0 3 0 4}^{c}$ \\
Furniture & $\mathbf{- 0 . 0 2 0 7}$ & $\mathbf{- 0 . 0 0 3 0 ^ { a }}$ & 0.0170 \\
& 0.0364 & 0.0006 & $\mathbf{0 . 0 2 3 8}$ \\
Miscellaneous & $\mathbf{- 0 . 0 0 9 4}$ & $\mathbf{- 0 . 0 0 1 2}$ & 0.0364 \\
& 0.0219 & 0.0008 & $\mathbf{0 . 0 1 0 6}$ \\
& & & 0.0218 \\
\hline
\end{tabular}

Province (reference: Ontario)

Pattern

U.S. first Simultaneous Non-U.S. first

Newfoundland

$0.0679^{a}$

$\mathbf{0 . 0 0 7 9}$

$-\mathbf{0 . 0 7 5 8} 8^{a}$

$(0.0096)$

$(0.0078)$

$(0.0055)$

Prince Edward Island

$-0.1001$

0.0124

0.0877

$(0.1659)$

(0.0193)

$(0.1616)$

Nova Scotia

$-0.0723$

0.0028

$0.0695^{c}$

(0.0409)

$(0.0031)$

$(0.0405)$

New Brunswick

$-\mathbf{0 . 0 7 1 3}$

$-0.0016$

0.0729

$(0.0487)$

(0.0019)

$(0.0485)$

Quebec

$-0.0353^{a}$

$0.0022^{a}$

$\mathbf{0 . 0 3 3 1}^{a}$

(0.0106)

(0.0009)

$(0.0105)$

Manitoba

0.0444

$-0.0002$

$-0.0442^{a}$

(0.0128)

(0.0015)

(0.0126)

Saskatchewan

$-0.0750$

0.0028

0.0723

(0.0472)

$(0.0031)$

$(0.0468)$

Alberta

$-0.0144$

$0.0025^{c}$

0.0120

$(0.0140)$

(0.0013)

(0.0139)

British Columbia

$-0.0197^{c}$

0.0012

0.0185 


\section{Predicted P}

Observed P
80.28

79.90
6.27

6.62
13.45

13.48

Notes: Marginal effects are evaluated at the means of the data. Standard errors are reported in parentheses below the coefficient estimates. "a", " $b$ " and "c" indicate statistical significance at the $1 \%, 5 \%$, and $10 \%$ level, respectively.

Compared to exporters belonging to the "Computer and Electronics" industry, it appears that exporters belonging to most industries are more likely to choose the "U.S. first" pattern. Exporters belonging to the "Wholesale Trade" industry, however, are less likely to choose the "U.S. first" pattern. Exporters belonging to the "Construction" industry are less likely to choose the "U.S.-first" and "simultaneous" patterns, but more likely to choose the "non-U.S. first" pattern. In summary, the evidence generally supports Hypothesis 3. That is, everything else being equal, firms that belong to the hightechnology sector are less likely to choose "U.S. first" relative to other patterns.

Figure 4 plots an average Canadian exporter's predicted probabilities of choosing all three categories of expansion patterns in relation to the year in which it started exporting. When comparing two hypothetical exporters that have the same characteristics (such as age, size, industry, location, etc.) except for the year they started to export, we see that the newer exporter's predicted probability of choosing alternative expansion patterns would be higher, while its predicted probability of choosing the "U.S. first" pattern would be lower than the older one. 
Figure 4 Predicted probability in relation to the year a firm starts to export

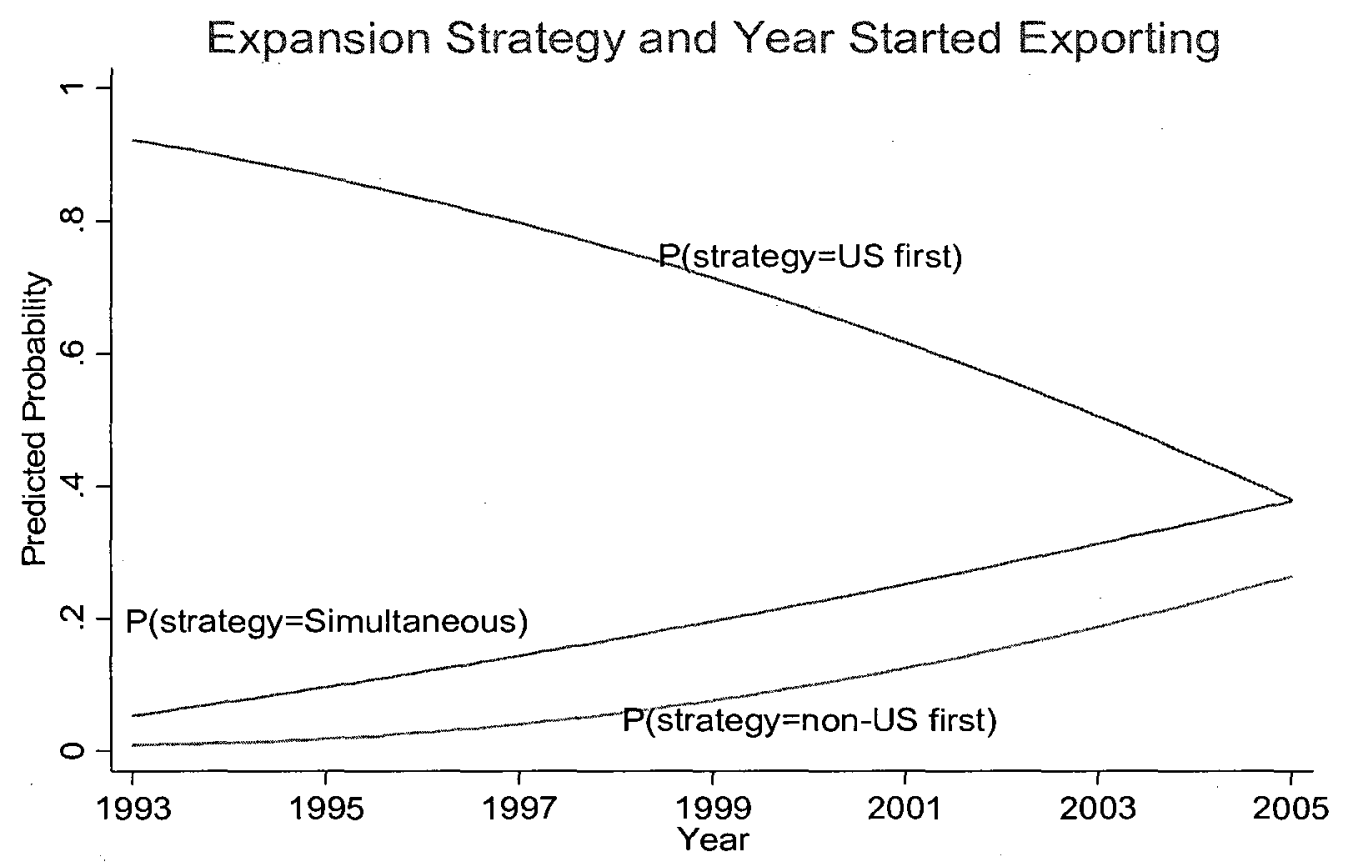

Preferably, a measure of total factor productivity (TFP) to compare the efficiency of firms would be constructed. Unfortunately, the available data does not permit construction of a TFP index. Following Wagner (2003), wage rate is used as a proxy for human capital intensity in order to reflect different levels of labor productivity. It appears from Table 6 that wage rate has no significant effect on their choice of foreign market expansion pattern. Therefore, Hypothesis 4- that the more productive a firm, the less likely it will choose the "U.S. first" pattern- is not supported.

In addition to the main results discussed earlier, many other interesting findings appear from Table 4. First, exporters specializing in exporting a smaller range of products are more likely to start exporting to non-U.S. foreign markets first. Second, singleestablishment firms are more likely to start exporting to both U.S. and non-U.S. 
destinations simultaneously than multi-establishment firms. Results that are related to firms' ownership and geographic location in the Canadian context are particularly interesting. For example, compared with Canadian-controlled exporters, U.S.-controlled firms are more likely to choose non-U.S. foreign markets but less likely to choose the U.S. market as their first export destination.

The results from Table 4 suggest that size has no influence on how firms choose their foreign market expansion pattern. Furthermore, everything else being equal, the younger the firm, the more likely it will export simultaneously to both the U.S. and non-U.S. markets. It appears that the exporting patterns chosen by non-U.S.-foreign-controlled firms are not affected by their ownership. U.S.-controlled firms, however, are more likely to choose non-U.S. rather that the U.S. market as their first export destination. The results could be due to the fact that those U.S.-controlled firms were exploring the wage difference between the U.S. and Canada.

Finally, compared with those located in Ontario (central Canada), exporters that are located in provinces such as "British Columbia" (west coast), "Nova Scotia" (east coast), and "Quebec" (a French language province) are more likely to choose non-U.S. foreign markets as their first export destination and less likely to choose the U.S. market as their first export destination. These results make sense because many firms located on the west coast have close ties with Asian countries, and those on the east coast may have close ties with European countries. On the other hand, firms that are located in Quebec, the only Canadian province whose sole official language is French, have better foreign institutional knowledge because they have a greater affinity with European countries than the U.S. in terms of language and culture (Florida and Stolarick, 2002). We also find that 
exporters located in provinces such as "Manitoba" and "Newfoundland" are more likely to choose the U.S. market as their first export destination. The finding for Manitoba could be due to the fact that the firms located in that province are remote from both the west and east coasts and, therefore, are more likely to sell their products to the South (i.e. the U.S. market). The structure of the economy in Newfoundland could account for the finding for this province. Since it is a fishery-based economy, the large and geographically close U.S. market provides a natural destination for its exports.

According to the estimated coefficients of the fitted model, the mean value of Canadian exporters' predicted probability to choose (1) the "U.S. first" strategy is $80.28 \%$ while the mean value of the observed probability is $79.90 \%$; (2) the "non-U.S. first" strategy is $13.45 \%$ while the mean value of the observed probability is $13.48 \%$; (3) the "simultaneous" pattern is $6.27 \%$ while the mean value of the observed probability is $6.62 \%$. Since the value of predicted probability is very close to the value of observed probability for each category, we may conclude that this model of expansion strategy fits well and has a high power of prediction.

\subsubsection{Assessment of Diagnostics and Robustness Test}

The most powerful assessment of a single predictor in logistic regression is the likelihood-ratio (LR) test, which approximately follows the chi-squared distribution. The LR test is computed by comparing the log likelihood from a full model, including all the explanatory variables, with that of a restricted model which excludes the tested variable $X_{k}$. A significance test at a conventional level such as 0.05 suggests that the 
variable $X_{k}$ should not be used in the model (our data support the hypothesis that $\left.\beta_{j k}=0, j=1, \ldots, J.\right)$.

Table 5 Likelihood-ratio test of coefficients

\begin{tabular}{|l|r|r|r|}
\hline Variables tested & LR Chi2 & Prob > Chi2 & Significant \\
\hline ExAge & 16.45 & 0.0002 & Yes \\
\hline Year & 25.14 & 0.0000 & Yes \\
\hline Size & -0.43 & 1.0000 & No \\
\hline Industry & 100.84 & 0.0000 & Yes \\
\hline Products & 30.39 & 0.0000 & Yes \\
\hline Country of Control & 13.10 & 0.0108 & Yes \\
\hline Multi-establishment & 17.45 & 0.0016 & Yes \\
\hline Province & 37.59 & 0.0002 & Yes \\
\hline Wage & 2.38 & 0.3049 & No \\
\hline
\end{tabular}

According to Table 5, the effect of 'ExAge', 'Year', 'Products', 'Country of Control', 'Multi-establishment', 'Province', and 'Industry' variables are statistically significant on the choice of expansion pattern at the 0.01 level. However, the hypothesis that the coefficients associated with 'Employees' and 'Wage' variables is equal to 0 cannot be rejected at the 0.10 level.

\subsection{Conclusion}

This paper studies the relationship between various firm-level characteristics of Canadian exporting enterprises on their choices of different foreign market expansion patterns. Exporters included in this study, as previously described, are categorized as following: "U.S. first", "non-U.S. first" and "simultaneous". As predicted by the stage model, the majority of Canadian exporters follow "U.S. first" pattern by choosing the U.S. as their first export destination, and expand subsequently to other foreign markets. After taking 
into account their location and industry, exporters that belong to the "U.S. first" category are typically more experienced in the international market, export more diversified of products, and are less likely to be U.S.-controlled.

The results of this study show that the traditional stage internationalization process is not universal to all firms. There is a considerable and growing minority of firms that do not conform to the stage model in two dimensions. Firstly, there are an increased number of Canadian exporters that implement the "simultaneous" strategy by initially exporting simultaneously to the U.S. and non-U.S. markets. Exporters that belong to this category are usually less experienced in both domestic and international markets. They are more likely to be product-diversified and single-establishment enterprises. Furthermore, if a firm belongs to the "Computer and Electronics" sector, or locates in Quebec, its probability of choosing the "simultaneous" pattern will increase.

Secondly, exporters who choose to export to non-U.S. foreign markets prior to the U.S. market are typically less experienced in the international market, less product-diversified, more likely to be both a U.S.-controlled and a single-establishment enterprise. Compared to exporters that belong to the "Computer and Electronics" sector, exporters that belong to sectors such as "Construction" and "Wholesale Trade" are more likely to choose this pattern while exporters that belong to the "Non-Metallic Mineral" are less likely to do so. Compared to the exporters that are located in Newfoundland, Ontario, and Manitoba, exporters that are located in Quebec are more likely to choose non-U.S. foreign markets as their first export destination, and then subsequently expand to the U.S. market. 
The findings from this study reveal the foreign market expansion patterns that have been implemented successfully by Canadian exporters. These findings are invaluable for the creation and development of effective trade and investment promotion policies. Canada is an economically small and trade-dependent country, whose well-being relies on trade more than any other industrialized country. Foreign market entry invariably involves risk and complexity. However, it is potentially very rewarding to those who succeed. Therefore, when entering foreign markets, there may be a role for the government to assist Canadian exporters in transforming global challenges into new exporting opportunities in the global marketplace. For example, if some particular classes of exporters typically use the U.S. market as their first point of entry into international markets and expand subsequently into other foreign markets, export promotion programs should then be designed to target the non-exporting firms of those classes with a focus on establishing a presence in the U.S. market. At the same time, programs supporting exporters to non-U.S markets should target exporters that are already exporting to the U.S. market. Alternatively, for those classes of Canadian exporters that start trading with non-U.S. markets, or that expand their business to both the U.S. and other foreign markets simultaneously, trade promotion programs (such as the emerging market strategy) could at that time be tailored accordingly.. As such, this research would enhance greater efficiency in delivery of trade promotion programs through better tailoring and targeting of the program. 


\title{
Chapter 3 Born Global, Gradual Global, and their Determinants of Exit from Exporting
}

\begin{abstract}
Applying the duration analysis to 1,959 newly established small and mediumsized Canadian exporting manufacturers; this study compares the survivability of Born Global and Gradual Global firms in the export market. The unique longitudinal (1997-2005) data set used in this study is constructed by linking multiple administrative data sources from Statistics Canada. With all else held constant, the probability of survival of Born Global is lower than Gradual Global firms. Once the endogeneity of a firm's choice of its internationalization process is incorporated into the analysis, differences in survival probabilities disappear. Further, the results show that Born Global and Gradual Global firms have notably different advantages and disadvantages while competing in the global export market. These findings have important implications for both academic researchers and policy-makers.
\end{abstract}




\section{1 Introduction}

A Born Global company is also referred to as an International New Venture (INV) or an International Entrepreneurship, and has been conceptualized as "a company which, from or near its founding, seeks to derive a substantial proportion of its revenue from the sales of its products in international markets" (Knight, 1997, p1). The phenomenon of Born Global has become a popular academic concern, since it challenges the traditional model of internationalization- the stage model. According to the stage model, the internationalization process of firms is "a process in which the enterprise gradually increases its international involvement" (Johanson and Vahlne, 1990, p11).

The purpose of this paper is to contribute to this debate by investigating the effect of different internationalization processes on the survivability of firms in the export market. There are two types of internationalization processes that this study compares: Born Global and Gradual Global. Specifically, a firm is classified as a Born Global if it has started to export within two years of its inception and during its first year of export activity, no less than $25 \%$ of its revenue is from exporting; otherwise, a firm is classified as a Gradual Global.

This paper makes three contributions to the literature. First, it contributes compelling evidence to a growing body of literature in the field of international business and international trade and has many important implications for international management, entrepreneurship, and strategic management by seeking to answer the following questions:

(1) What is the effect of Born Global process on the survivability of firms in the export market? 
According to a review study by Keupp and Gassmann (2009), there have been at least 179 articles on Born Global published in 16 top-tier journals over the past 14 years. The only study that examined the survival of Born Global is written by Mudambi and Zahra in 2007. While Mudambi and Zahra's study identified the survivability of Born Globals in the domestic market, the survivability of Born Globals in the global export market were not investigated. By investigating this question, this study contributes to the debate between the stage model and the Born Global phenomenon. For example, the evidence of a negative effect of Born Global process on the survivability of firms in the export market may imply that the Gradual Global process could increase firms' probability of survival in the global market, and thus, support the idea of the stage model. On the other hand, the evidence of a positive effect of Born Global process on the survivability of firms in the export market may imply that Born Global process is a strategic choice for a particular group of young firms. These firms would have a lower probability of survival in the export market if they had chosen the traditional gradual global internationalization process.

(2) What are the factors that determine Born Globals' survival in the export market? What are the factors that determine Gradual Globals' survival in the export market?

Export activity is an important catalyst for the growth of young firms (Oviatt and McDougall, 1994; Zahra, Ireland, and Hitt, 2000) since the uncertainty and risk of exposing young firms to foreign markets will trigger their dynamic capability for exploiting new opportunities and resources (Sapienza et al., 2006). A study by Eaton et al. (2007) on Colombia exporters found that only a small fraction of new exporters are able 
to continue exporting in the following year. However, these successful new exporters account for almost half of total export expansion in less than ten years. Therefore, it is important to identify the factors that determine the success or failure of new exporters in the international market. Furthermore, by identifying factors that determine the survival of Born Global in the export market, especially factors that are different from those that determine the survival of Gradual Globals. The results of this paper enrich our understanding of the comparative advantages of Born Global firms in the global export market.

Answering these questions requires quality dynamic firm-level data. After reviewing and assessing fifty-five empirical studies that were published between 1989 and 2002 within the field of Born Global, Coviello and Jones (2004) noted that Born Global research is characterized by static, readily obtainable, and judgment-based data. Among these fiftyfive studies, only five studies are longitudinal and twelve studies used random selection in their sample design. In contrast, my data set is drawn from three large-scale administrative databases from Statistics Canada: the Exporter Register (1993-2005), the Business Register (1997-2005), and the Longitudinal Employment Analysis Program (1997-2004). The Exporter Register, the major database that is used in this study covers the universe of Canadian exporting firms that made at least one shipment to a foreign market from 1993 to 2005 . Therefore, the second contribution of this study stems directly from the unique longitudinal firm-level data set I constructed, which includes the export activities of a relatively large sample of Canadian firms between 1997 and 2005.

Third, in recognition of the possibility that a firm's choice on its internationalization process is endogenous, simple comparisons of Born Global and Gradual Global firms are 
unlikely to have a causal interpretation on the effect of Born Global process on the survivability of firms in the export market. Therefore, this study applies a two-stage estimation methodology to correct for the selectivity bias. The Split-Sample Instrumental Variable (SSIV) methodology (Angrist and Krueger, 1995; Bolduc et al., 2008; Huynh et al., forthcoming) is applied to check for the robustness of the results. Furthermore, a reduced-form duration model, the Cox proportional hazard model, is employed to examine the survivability of firms in the export market. Compared to the logit model that has been applied in Mudambi and Zahra's (2007) study, the hazard model that has been applied in this study has many advantages. Firstly, the logit model can only address the unconditional probabilities, such as a firm's probability to exit from exporting in a moment $t$. The hazard model, on the other hand, allows me to address the conditional probabilities, such as a firm's probability to exit from exporting in a moment $t$, given that it has continuously exported until this period $t$. Secondly, to use the logit model, the researcher needs to select the time when firms' characteristics are observed. This selection bias may cause the estimated probabilities to be biased and inconsistent with the true probabilities. Contrarily, the hazard model can produce more efficient and consistent results by accounting for the duration dependence and using all the available information at each point in time.

The rest of this paper begins with a review of the relevant literature and the hypotheses to be tested in section 2. Section 3 explains the data and section 4 explain the methodology utilized in this study. Section 5 presents empirical results with discussions. Finally, concluding remarks are discussed in section 6. 


\section{2 Theory and Hypotheses}

Despite the increase in Born Global studies, neither the name nor the definition of such groups of firms has been universally accepted (Keupp and Gassmann, 2009). Such groups of firms have been given different names such as Born Internationals (Ray, 1989), Born Globals (Rennie, 1993), and International New Ventures (Oviatt and McDougall, 1994). Different conceptual definitions have also been offered by researchers to describe Born Globals. Examples include: "a business organization that, from inception, seeks to derive significant competitive advantage from the use of resources and sale of outputs in multiple countries" by Oviatt and McDougall (1994, p. 470); firms that "adopt an international or global approach right from their birth or very shortly thereafter" by Madsen and Servais (1997); "a young entrepreneurial company that initiates international business activity very early in its evolution, moving rapidly into foreign markets" by Cavusgil et al. (2008), and "SMEs with accelerated internationalization potential and global market vision" by Gabrielsson et al. (2008).

Regardless of different definitions, what these firms have in common is their early and fast approach as opposed to the gradual approach of internationalization processes that have been described by the traditional internationalization model--the stage model. The stage model, or the Uppsala model, is the earliest internationalization model that was developed by a group of Swedish economists (Johanson and Wiedersheim-Paul, 1975; Forsgren and Johanson, 1975) who worked at the Uppsala University. A considerable number of empirical studies have found evidence that supports this model from different countries. Examples are Johanson and Wiedersheim-Paul (1975) on Swedish firms, Welch and Luostarinen (1988) on Finnish industrial companies, and Lam and White 
(1999) on small companies in the UK. According to the stage model, firms are cautious and become involve gradually in foreign business activities because of the risks and uncertainty associated with foreign market entry and survival. Therefore, if the stage theory is relevant, Born Globals would have a lower chance of survival in the foreign markets than the Gradual Globals.

Beginning in the early 1990s, however, a number of empirical studies in the have reported an intriguing phenomenon that contradicted the traditional internationalization theory $^{13}$. Brush (1992) found that $13 \%$ of small U.S. manufacturers had started international activities during the first year of operations. Rennie (1993) observed that about $25 \%$ of Australian exporters began exporting in substantial quantities right from the birth of the company. In their seminal work, Oviatt and McDougall (1994) argued that the stage model cannot be applied in some cases, especially among newly established firms who belong to industries that are characterized by intense international competition and unique knowledge. Similar conclusions have been made by other empirical studies such as Bell's (1995) study on computer software companies and Shrader's (2001) study on high-technology new ventures.

\subsubsection{The Effect of Born Global Process on the Survival of New Exporters}

Sapienza et al. (2006) developed a dynamic capabilities framework to explain the effect of Born Global process on firm survival and growth. Based on this theoretical framework, Born Global firms may experience lower survival rate than Gradual Global firms because they need time to develop routine organizational processes and positional advantages in

\footnotetext{
${ }^{13}$ Studies by Zahra (2005) and Meckl and Schramm (2005) are two recent reviews on the theory and empirical evidence of Born Globals.
} 
the foreign market. A study by Zahra (2005) made the same prediction, that Born Globals would have a relatively lower probability of survival because of their disadvantage in organizational age, prior managerial experience, and resource constraints.

In the Industrial Organization literature, one of the stylized facts is that age and size are positively related to the probability of a firm's survival (Geroski, 1995). For example, decreasing hazard rates with age has been found among U.S. firms (Audretsch and Mahmood, 1995), Canadian firms (Baldwin and Gorecki, 1991), and Portuguese firms (Mata et al., 1995). New firms need time to develop their new organizational capabilities and face a high probability of exit (Stinchcombe, 1965). The age-effects on survival, or the so-called liability of "newness" 14 , refer to the time firms need to establish themselves, carry out specific investments, develop knowledge and appropriate production routines, and build up networks with business partners. Based on this argument, by choosing to become international in a slow and incremental manner, Gradual Global firms could have a better chance of survival in the foreign markets by gaining knowledge and experience and building up sufficient capacity for selling their products worldwide over time.

In the field of International Entrepreneurship, Born Global combines "innovative, proactive, and risk-seeking behaviour that crosses national boundaries and is intended to create value in organizations" (McDougall and Oviatt, 2000, p903). Younger firms, as reported by Ursic and Czinkota (1984), are often lacking cost advantages, including sufficient amounts and sources of resources and financial assistance to help them

\footnotetext{
${ }^{14}$ The terminology of the liability of newness is original from Freeman et al. (1983).
} 
compete in the local market. Hence, young firms are more interested in the global market than the more established firms. Conditional on "improvements in global telecommunications and transport networks, combined with increasingly liberalized global trading regimes" (Fan and Phan, 2007, p1113), Born Global process is a strategic choice for a particular group of firms. For example, the founders of these companies may be familiar with foreign markets because of their prior international business experiences (Knight and Cavusgil, 1996; Oviatte and McDougall, 1997). In this case, a firm's decision on its internationalization process is endogenous. Consequently, one has to take into account the endogeneity of a firm's choice on its internationalization process when assessing the effect of Born Global process on the survivability of firms in the export market.

To the best of the author's knowledge, the effect of Born Global process on the survival of firms in the export market has not been investigated empirically. The existing empirical evidence on the survival of Born Globals is not entirely conclusive. A study by Mudambi and Zahra (2007) found that Born Globals are significantly less likely to survive than established firms. However, the lower probability of survival associated with Born Globals disappears when the endogeneity of a firm's choice on its internationalization process is taken into account. The results of their study suggest that early internationalization may be a value-maximizing organizational form and an endogenous optimal strategy for a particular group of firms. Empirical models that do not account for self-selection of strategy choice, as suggested by Shaver (1998), can be misspecified, and lead to incorrect conclusions. 
The theoretical considerations described above yield two hypotheses with regard to the effect of the Born Global internationalization process on the survivability of firms in the export market which I will explore empirically:

Hypothesis 1a: Everything else being equal, Born Globals have a higher probability of exit from exporting than Gradual Globals.

Hypothesis 1b: After endogenizing a firm's choice on its internationalization process, Born Globals have no greater a probability of exit from exporting than Gradual Globals.

\subsubsection{Exit from Exporting of Born Global and Gradual Global Firms}

Productivity. In the international trade literature, studies from the microeconometrics of international firm activities have noticed the superior performance of exporters relative to non-exporters (e.g. Bernard and Jensen, 1999; Isgut, 2001, Clerides et al., 1998; Delgado et al., 2002). For example, firm-level evidence from European countries revealed that internationalized firms are "superstars", they "are bigger, generate higher value added, pay higher wages, employ more capital per worker and more skilled workers, and have higher productivity". (Mayer and Ottaviano, 2007, p11)

An important theoretical framework to explain such findings is the Melitz (2003) model with heterogeneous firms. The Melitz model is a theoretical model that incorporates firm heterogeneity into the Krugman's (1979) monopolistic competition framework. In that model, there are fixed costs and variable costs associated with entering the industry and entering the export market. As a result, only a small fraction of productive firms engage 
and remain in exporting. Furthermore, wage is used as a proxy for human capital intensity by Wagner (2003) to reflect different levels of labor productivity. Based on Wagner's argument, one would expect firms that pay higher wage rates to be more productive, and thus, more likely to survive in the export market. The least productive firms are forced to exit. These arguments lead to the following hypotheses:

Hypothesis 2a: Everything else being equal, firms that produce more revenue per worker have higher probability of survival in the export market.

Hypothesis 2b: Everything else being equal, firms that pay higher wage rates have higher probability of survival in the export market.

Export Market Diversification. Geographic concentration of export destinations leaves exporters vulnerable to rapid changes in the political or economic situations of their key trade partners. By exporting to multiple destinations (especially countries with different business cycles, exchange rate regimes, etc.) exporters are less likely to run the risk of depending on one trading partner, and thus, can maintain a certain level of threshold to be profitable. Hence, more market diversified exporters are more likely to survive in the international market. Similar arguments can be applied to product diversification. In other words, exporting to more destinations and more varieties of products could provide an insurance benefit to exporters because the risks of uncertain demand are less correlated for different types of markets and products. Furthermore, a study by Eaton et al. (2005) suggested that more productive firms should be able to export to more destinations. Consequently, more diversified firms are more productive, and are more likely to survive 
in the export market. These arguments lead to the following hypothesis:

Hypothesis 3a: Everything else being equal, firms that are more market-diversified are more likely to survive in the export market.

Hypothesis 3b: Everything else being equal, firms that are more product-diversified are more likely to survive in the export market.

U.S. first. A study by Sabuhoro et al. (2006) suggested that for Canadian firms, choosing the U.S. as the first export destination has a positive effect on their probability of survival in the export market. This result is consistent with the idea of the stage model, which stimulates that after building strong appearances in the domestic market, firms often export first to a single neighboring market and subsequently enter more distanced foreign markets (Bell, 1995). This finding is also consistent with a study conducted by Eaton et al. (2007), who investigated the cross market dynamics of Colombian firms from 1996 to 2005. The authors showed that it appears to be a popular geographical expansion strategy for Colombian exporters to present themselves gradually from a single neighboring foreign market to additional destinations within the regional market, and then reach to larger OECD markets. Eaton et al. suggested that the likelihood of the survival of exporters depends on their choice of initial market destination since success in neighboring markets may suggest that the expected payoff could exceed the sunk cost in more distanced markets. 
When it comes to Born Global firms, however, physical distance is arguable to be less important during their internationalization process (Boter and Holmquist, 1996; Keeble et al., 1998; Madsen et al., 2000). These arguments lead to the following hypotheses:

Hypothesis 4a: Everything else being equal, choosing the U.S. as the first export destination has a positive effect on the survivability of Gradual Global firms.

Hypothesis 4b: Everything else being equal, choosing the U.S. as the first export destination does not affect the survivability of Born Global firms.

\section{3 Data}

\subsubsection{Data Sources}

The data I constructed to examine my research questions gathers information from the

Exporter Register (ER), the Business Register (BR), and the Longitudinal Employment Analysis Program (LEAP). The data set documentation is provided in Chapter 1.

\subsubsection{Sample Selection}

I now present the criteria and procedure of selecting observations. A study on the conceptual definition of Born Global by Gabrielsson et al. (2008) emphasized that Born Global firms should be "small and medium-sized enterprises (SMEs) with accelerated internationalization potential and global market vision". When it comes to defining Born Globals, one should take into account "factors such as the type of industry" (Gabrielsson et al., 2008). Consistent with Gabrielsson et al.'s definition, I selected manufacturing firms established between 1997 and 2004 that hire 500 or fewer employees. I constructed my data set at the enterprise level. Any reference made to "exporter" or "firm" in this 
study represents a "statistical enterprise". A unique and static identification number (id) is assigned to each firm in each the databases used in this study. My sample is reduced to 3,061 enterprises after linking the aforementioned databases by using this firm id as a time-invariant identifier. I eliminated 662 enterprises with annual revenue of $\$ 30,000$ Canadian dollars or less ${ }^{15}$ (remaining sample 2,399). To ensure that exports are an important part of a firm's business activity, I eliminated 420 enterprises whose annual value of exports is $\$ 2,000$ Canadian dollars or $\operatorname{less}^{16}$ (remaining sample 1,979). Finally, I eliminated enterprises with exceptionally high or low revenue per employee (the highest and the lowest both $0.5 \%$ ). I am left with the analysis sample of 1,959 enterprises.

\subsubsection{Construction of the Variables of Interest}

In the Appendix, Table 10 presents definitions, data sources, and descriptive statistics for the variables used in this paper. I constructed the following variables in order to classify the Born Global firm. The variable 'BRBY', Business Register Birth Year, is estimated by the first year a firm appeared in the BR database, which is used as a proxy for the first year a firm began its business. Since the BR database starts in 1987, information prior to 1987 is unknown for those firms which entered the BR database in 1987. Accordingly, I generated a set of dummy variables 'Cohort', which equal one if a firm starts its business in a particular year. An exporter may register in the ER before it registers in the BR database. Such exporters are usually individuals who have to register in the ER database

\footnotetext{
${ }^{15}$ It is a well documented fact that in the administrative databases, such as the Exporter Register database that is used in this study, the business behaviors of many firms are very irregular and not suitable for research purposes. Therefore, this study uses $C \$ 30,000$, the same threshold that is used in the Exporter Register database, to eliminate irregular firms.

${ }^{16}$ Export transactions to non-U.S. destinations that are valued at less than $\$ 2,000$ need not be reported by the Canada Revenue Agency. Therefore, this study uses $\mathrm{C} \$ 2,000$ as a threshold to eliminate irregular exporters.
} 
because they need to ship products to a foreign buyer. They do not have to register in the BR database unless they want to form a company. Therefore, such a firm is not considered a firm until it registers in the BR database in this study. The variable 'ERBY', Exporter Register Birth Year, is estimated by the first year a firm registered in the ER database, which is used as a proxy for the year a firm began to export.

Accordingly, a firm's export start-up age, 'ExAge', is measured by the difference between a firm's ER Birth Year and BR Birth Year plus one. If a firm enters the BR database and the ER database in the same year, its start-up age equals one. If a firm enters the ER database before it enters the BR database, its export start-up age equals one as well. Enterprises that do not register in the BR database are not considered as firms, and thus, were excluded in my data set.

The variable 'Exports' is measured in millions of Canadian dollars from the ER database and is deflated by annual merchandise exports customs-based price indexes, using base year 2000. The variable 'Exports' is available annually from 1993 to 2005. 'Revenue' is a proxy for the size of a firm measured in millions of Canadian dollars from the BR database and is deflated by annual industry price indexes, using base year 2000 . The variable 'Revenue' is available annually from 1997 to 2005 . A firm's export intensity, 'EI', is measured as the ratio of export sales to revenue of the firm and is available annually from 1997 to 2005 . I found that some firms have a higher level of exports than revenue. One possibility is that the moment a firm reports its revenue might be different than the moment it reports its exports, which is referred to as a calendar issue. Another possibility is that either the value of exports or the value of revenue, or both are incorrectly entered. I let the export intensity of such enterprise equal one. 
'BG' is a dummy variable that equals one if a firm starts to export within two years of its inception and has exported no less than $25 \%$ of its total revenue during the first year of its export activity. Accordingly, 497 out of 1959 (25.37\%) firms are classified as Born Global in this study.

I constructed the following variables that might influence a firm's survivability in the export market. Based on a firm's country of control from the BR database, I generated a dummy variable 'Foreign', which equals one if a firm's home country of owner is not Canada. The percentage of foreign-owned firms in my sample is $1.68 \%$. Based on a firm's corresponding five-digit North American Industry Classification System (NAICS5) code from the ER database, I constructed a dummy variable 'ICT', which equals one if a firm belongs to the information and communication technology (ICT) sector. In general, the ICT sector is defined as the combination of manufacturing and service industries that electronically capture, transmit, and display data and information (Statistics Canada, 2001). The percentage of ICT firms in my sample is $7.5 \%$. Table 11 in the Appendix presents the corresponding NAICS5 codes that are classified as ICT sectors. This classification was developed by Statistics Canada and Industry Canada in 1999.

From the ER database, I know the first year each firm enters each market. I generated a dummy variable 'U.S. first', which equals one if a firm exports to the U.S. before it exports to another country. If a firm only exported to the U.S. market, it is considered as having chosen the U.S. as its first destination and is included in the 'U.S. first' category. The percentage of firms that choose the U.S. as their first export destination in my sample is $81.98 \%$. This result suggests that newly established small and medium-sized Canadian manufactures are highly dependent on the U.S. market. 
Based on a firm's corresponding NAICS3 code from the ER database, I generated a set of dummy variables 'Sector', which are set at one if a firm belongs to a particular sector. There are eleven sector groups in this study. Based on a firm's corresponding 2-digit province-of-location categorical variable from the ER database, I generated a set of dummy variables 'Province', which equal one if a firm is located in a particular province. If a firm has plants in multiple provinces, I used the province in which the firm derives the highest share of it value of exports as its province of location.

'Employees' is measured by the individual labor unit (ILU) and is available annually from 1997 to 2005 from the LEAP database. As aforementioned, an ILU represents one employee in most cases. In cases where one person works for several companies in a year, his or her individual labor unit is distributed proportionally among the enterprises. A parttime worker would still contribute one ILU to the total if he or she did not work for another enterprise. The variable 'Labor Productivity' is calculated by the ratio of revenue to the number of employees and is available annually from 1997 to 2005 . It is measured in thousands of Canadian dollars and is deflated by annual industry price indexes, using base year 2000. The variable 'Wage Rates' is calculated by the ratio of total payroll to the number of workers and is available annually from 1997 to 2005 . It is measured in thousands of Canadian dollars and is deflated by annual consumer price indexes, using base year 2000 .

The variable 'Products' refers to the variety of products a firm exported based on the count of its HS8 code from the ER database, which is used as a proxy for a firm's degree of product diversification. The variable 'Products' is available annually from 1993 to 2005. The variable 'Destinations' is measured by the number of countries to which a 
firm exported from the ER database, which is used as a proxy for a firm's degree of destination diversification. The Variable 'Destinations' is available annually from 1993 to 2005 .

I constructed the following variables for the purpose of the duration analysis. The dummy variable 'Censor' is set at one if a firm is exporting in the year which the period of observation is terminated. 1395 out of 1959 (71.21\%) firms in my sample were still exporting in 2005, and thus, their corresponding value of variable 'Censor' equals one.

Most studies on the exit and entry of exporters consider a firm as having stopped from exporting if it stays out of the export market for one year or longer. To account for the seasonality in firms' export behavior, the following estimation convention is adopted in this study: a firm is considered as having stopped exporting if it stays out of the export market for two consecutive years or longer. Based on this methodology, the variable 'Duration' is defined as the number of years a firm remains active in the export market. There are 81 out of $1959(4.13 \%)$ firms that export over the whole period (1997-2005) in my sample, and thus, their corresponding export duration is nine years. Moreover, to estimate the effect of previous exits on survival time, I generated a dummy variable ' $\mathbf{R e}$ enter' that is set at one if a firm reenters the export market.

\section{4 Empirical Methodology}

\subsubsection{Duration Analysis}

This study uses a reduced-form model to identify the determinants of the ability of Born Globals' to remain active in the export market. The statistical software I used for my 
analysis is STATA 10. My aim is to identify the factors that affect a new exporter's instantaneous probability of exit from exporting.

In the duration analysis, the variable of interest is the length of uninterrupted time that elapsed between a firm's entry and exit in the export market. Let $T$ denote the duration of exports and $t$ denote a particular value of $T$. The survivor function $S(t)$, the probability that the duration of the spell $T$ equals or exceeds the value $t$, is defined as follows:

$S(t)=P(T \geq t)=\int_{t}^{\infty} f(x) d x=1-F(t)$

where $f($.$) is the probability density function (pdf) and F($.$) is the cumulative$ distribution function (CDF) for $T$.

Following Lancaster (1990, chapter 2), the hazard rate of firm $i$ is defined as the instantaneous probability of $i$ exiting the global market in a moment $t$, given that it has continuously exported until this period $t$, and conditional on a vector of covariates $X_{i t}$, which includes both time-invariant and time-varying variables,

$$
\lambda\left(t_{i} ; x_{i t}\right)=\lim _{h \rightarrow 0} \frac{P\left(t_{i} \leq T<t_{i}+h \mid T \geq t_{i}, x_{i}\right)}{h}
$$

where $T$ is specified as a non-negative random variable. I assume that $T$ is a continuous variable, so that for each $t, \lambda\left(t_{i}\right)$ is the instantaneous exit rate for firm $i$.

This study uses the semi-parametric Cox proportional hazard model (CPHM) specification. CPHM is flexible in the specification of the baseline hazard $\lambda_{0}\left(t_{i}\right)$, which allows for a proportional specification for unobserved heterogeneity, and a function of 
observables. The proportional hazard model with time-varying covariates was first introduced by Cox in 1972. A particular advantage of the Cox model is that the baseline hazard is left unspecified and is not estimated. The basic proportional hazard model takes the form of:

$\lambda\left(t_{i} ; x_{i}\right)=\lambda_{0}\left(t_{i}\right) \cdot \exp \left(\beta_{1} x_{1}+\ldots+\beta_{k} x_{k}\right)$

where $\lambda_{0}\left(t_{i}\right)$ is the baseline hazard for firm $i$, which measures the hazard of an individual firm for whom all covariates are zero at a given time $t$. I introduce a transformation function $g\left(t_{i}\right)$ into above regression as the following:

$\lambda\left(t_{i} ; x_{i t}\right)=\lambda_{0}\left(t_{i}\right) \cdot \exp \left\{\beta_{1} x_{1}+\ldots+\beta_{k} x_{k}+g\left(t_{i}\right)\left(\gamma_{1} z_{1}+\ldots+\gamma_{m} z_{m}\right)\right\}$

where variables $\left(z_{1}, \ldots, z_{m}\right)$ are independent of time. However, the transformation function $g\left(t_{i}\right)$ makes $g\left(t_{i}\right)\left(\gamma_{1} z_{1}+\ldots+\gamma_{m} z_{m}\right)$ vary continuously with time.

\subsubsection{Counting Process Approach for Multiple Failure Events}

The event of exit from exporting may occur more than once for a given firm during the research period, since a firm may enter, exit, and then re-enter the export market. Such events are called "multiple events", or "recurrent events". To model this type of event, I used the CPHM and converted the multi-failure event data to a replicated-process singlefailure event data, by assigning a new identification number to a firm if it re-enters the export market. This approach is called the Counting Process Approach (Andersen et al., 1993). Alternatively, I can restrict the analysis to the first event of the multiple events only. The drawback of such an approach is that it cannot estimate the effect of a past event on the occurrences of a new event. 
This study focused on the Counting Process Approach, but also assigned a set of dummy variables to each firm to indicate the number of times a firm enters the export market. As I mentioned in the data section, a firm is considered as having stopped exporting if it stays out of the export market for two consecutive years or longer. Based on this estimation method, the maximum number of times a firm could re-enter the export market between 1997 and 2005 is three times. My data set has an observation of 1,959 firms. The number of firms that entered the export market once, twice, and three times are $1,395(71.21 \%), 112(5.72 \%)$, and one $(0.05 \%)$, respectively. In total, my data set includes 2,072 single events.

This length of time is measured in years, which can be either fully observed as a complete spell, or partially observed as an incomplete spell due to the fact that some firms have an export duration that pass the observed period. The second type of spell is defined as a censored spell in the context of duration analysis. More specifically, a spell is left censored if the firm exported in the first sample year. To minimize the left censor problem, this study only focused on new exporters. A spell is right censored if the firm is still exporting in the last sample year. My data set has an observation of 1,959 firms, of which 1,395 are right censored (71.21\%).

\subsubsection{Two-Stage Estimation Methodology}

The aim of this study is to investigate the effect of Born Global process on the survivability of firms in the export market. In general, the indicator for those who choose the Born Global internationalization process is endogenous, because the firms who choose this strategy perceive that this strategy is beneficial for their long-run profit or export market survivability. In recognition of possible endogeneity of a firm's choice on 
its internationalization process (Masten, 1993), I used a two-stage estimation methodology that is similar to Mudambi and Zahra's (2007).

At the first stage, I use a probit model to formulate a firm's internationalization process decision between Born Global and Gradual Global ${ }^{17}$. Because a firm's decision on whether or not to choose the Born Global internationalization process is made at its inception, the setting of this model is cross-sectional.

In general, when a firm's expected value of return in choosing the Born Global process is greater than its expected value of return in choosing the Gradual Global internationalization process, the firm will choose the Born Global internationalization process. Otherwise, the firm will choose the Gradual Global internationalization process.

I defined the variable $B G_{i}^{*}$ as the difference in the expected value of return between the Born Global and Gradual Global internationalization processes for a new firm $i$. This value, and hence the chosen internationalization process, is a function of measurable firm attributes and cohort conditions and a disturbance term. I cannot observe $B G_{i}^{*}$ but I can observe the chosen internationalization process $\left(B G_{i}=1\right.$ if Born Global, $B G_{i}=0$ if Gradual Global) and thus infer whether or not $B G_{i}^{*}$ is positive or negative. This is the standard formulation of a dichotomous choice model, which can be represented by the following equation:

$$
B G_{i}^{*}=\alpha_{j} Y_{i}+v_{i}, \quad B G_{i}=1 \text { if } B G_{i}^{*}>0, \text { and } 0 \text { otherwise. }
$$

\footnotetext{
${ }^{17}$ The discussion is drawn from Shaver's (1998)'s empirical model on a firm's foreign direct investment entry decision between acquisition and greenfield.
} 
where $Y_{i}$ is a vector of independent variables (which includes a constant term) and $\alpha_{j}$ are the coefficients I estimate. I assumed $v_{i}$ is normally distributed with zero means and unit variance. Furthermore, $v_{i}$ represents additional unobserved effects that might affect a firm's choice between the Born Global and Gradual Global internationalization processes.

More specifically, BG is the dependent variable in the binary choice model. In this study, BG equals one if a firm starts to export within three years of its inception and has exported no less than $25 \%$ of its total revenue during the first year of its export activity. The vector of independent variables includes initial firm conditions (number of employees, revenue per employee, and payroll per employee), $I C T_{i}$ (a dummy variable and which equals one if a firm belongs to the ICT sector), $F_{i}$ (a dummy variable which equals one if a firm is foreign-owned), $S_{i}, P_{i}$, and $C_{i}$ (sector-, province- and cohortspecific dummy variables respectively).

Accordingly, I estimate $B G_{i}$, a firm's predicted probability of choosing the Born Global internationalization process conditional on $Y_{i}$ :

$$
\hat{B G_{i}}=\hat{\alpha}_{j}^{\prime} Y_{i}
$$

At the second stage, I used the CPHM to estimate the effect of Born Global process on the survival of firms in the export market. I have discussed the $\mathrm{CPH}$ model in detail in Section 4.1. In this section, to emphasize the importance of accounting for the endogeneity, I use a simplified specification as the following:

$$
\text { Survival }_{i}=\beta^{\prime} X_{i}+\eta \hat{B G_{i}}+\xi_{i}
$$


Survival $_{i}$ is the probability of survival of firm $i, X_{i}$ is a vector of independent variables that may affect the survival of the firm, which includes initial firm conditions (number of employees, revenue per employee, and payroll per employee), current firm conditions (number of employees, revenue per employee, payroll per employee, variety of products exported, and number of export destinations). USfirst $_{i}$ is a dummy variable which equals to one if a firm chose the U.S. as its first export destination), $I C T_{i}$ (a dummy variable and which equals one if a firm belongs to the ICT sector. $F_{i}$ is a dummy variable which equals one if a firm is foreign-owned. $S_{i}, P_{i}$, and $Y_{i}$ are sector-, province- and yearspecific dummy variables, respectively. $\hat{B G}_{i}$ is the estimated probability for firm $i$ to choose the Born Global internationalization process, and $\xi_{i}$ is an error term that is normally distributed with zero means and unit variance.

Why could the endogeneity of firms' internationalization process choices lead to biased coefficient estimates? Suppose I estimate Equation (7) without accounting for the endogeneity on a firm's choice on its internationalization process with the following equation:

$$
\text { Survival }=\beta^{\prime} X_{i}+\delta B G_{i}+\varepsilon_{i}
$$

where $B G_{i}$ is a binary variable that indicate whether the internationalization process of firm $i$ is Born Global or not, and $\varepsilon_{i}$ is an error term that is normally distributed with zero means and unit variance. In addition, $\varepsilon_{i}$ represents the unobserved effects that may influence the survival of firms in the export market that are not included in $X_{i}$. 
If unobserved effects captured in $\varepsilon_{i}$ are the same as in $v_{i}$, these two error terms will be correlated. For example, prior international business experience of the founder of the company may increase the likelihood of the firm to choose the Born Global internationalization process, as well as increase the likelihood for the firm to survive in the export market. Since such effect is not captured in either $Y_{i}$ or $X_{i}$, it is captured in $v_{i}$ and $\varepsilon_{i}$. Therefore, $v_{i}$ and $\varepsilon_{i}$ are correlated. In this case, the estimation of $\delta$ will not have desirable statistical properties, and the use of $\delta$ to interpret the effect of Born Global process on the survival of firms in the export market would likely be misleading (Shaver, 1998).

\subsubsection{Split-Sample Instrumental Variable Estimation}

The method of the Split-Sample Instrumental Variable (SSIV) is applied to check for the robustness of the results. This method has been applied by, for example, Bolduc et al. (2008) and Huynh (forthcoming). According to Angrist and Krueger (1995), unlike conventional IV estimates, SSIV estimates are biased toward zero regardless of the degree of covariance between structural and reduced-form errors or the first-stage $R^{2}$. An unbiased estimate of the attenuation bias of SSIV is given by the coefficient from a regression of the endogenous regressor on its predicted value, using data from one half of the sample but using first-stage parameters from the other half.

Accordingly, I randomly split the sample in half and use one half of the sample to estimate parameters of the first-stage (binary choice model) equation. These estimated first-stage parameters are then used to construct fitted values for the endogenous regressor from data in the other half of the sample. After that, the predicted values of the 
endogenous regressor are used in the second-stage (duration analysis) parameter estimates.

\subsubsection{Separated Hazard Function for Born Globals and Gradual Globals}

The second aim of this study is to identify the factors that are related to the long-run survival of Born Globals and Gradual Globals in the export market. Until now, I assumed that the survivability of exporting of Born Global and Gradual Global firms is explained by the same factors, and these factors differ only by a proportional factor. However, such assumptions may discard the possibility that the survivability of exporting of Born Global and Gradual Global firms is determined by different factors. One approach to overcome such limitations is to estimate the model separately for Born Global and Gradual Global firms. This approach would not enforce a common baseline hazard function across the two groups, nor equal effects of the independent variables.

For the above reasons, I ran separate regressions for Born Globals and Gradual Globals. I control for heterogeneity among firms by including variables that are expected to affect the survival of firms in the export market: the initial firm conditions, such as initial firm size, labor productivity, and wage rates; the time-invariant firm-specific characteristics, such as ICT, foreign-owned, and U.S.-first; the time-varying firm-specific characteristics, such as the present firm size, labor productivity, wage rates, number of export destinations, and variety of products exported. The inclusion of sector-specific dummy variables is important to capture the industry variations in unobserved factors in the data. For the same reason, it is important to include province-specific and cohort-specific dummy variables. 


\section{5 Results}

\subsubsection{Classification of Firms}

Although there are many different numerical classifications of Born Globals, the common criteria that have been used to classify Born Globals are start-up age (age of the firm when it started to export) and export intensity (proportion of revenue that is exported). The period of time a firm must internationalize to be considered as a Born Global firm ranges from two years by McKinsey and Co. (1993) to eight years by McDougall et al. (1994). It is imprecise in the literature on the proportion of revenue that must be exported for a firm to be considered as a Born Global firm. The minimum export intensity a firm must achieve to be considered as a Born Global firm ranges from $5 \%$ by Zahra et al. (2000) to $80 \%$ by Chetty and Campbell-Hunt (2004). Most studies (Rennie, 1993; Moen and Servais, 2002; Madsen et al., 2000) have used the criteria of $25 \%$ that is proposed by Knight and Cavusgil (1996).

Considering the entry cohort of firms (1997-2004) and the research period (1997-2005) of my data set, I decided to specify a firm as a Born Global if it has started to export within two years of its inception and has exported no less than $25 \%$ of its revenue during the first year of its export activity. The rest of the firms in my sample are classified as Gradual Globals. According to this classification, the number of firms classified as Born Global is $497(25.37 \%)$, and the number of firms classified as Gradual Global is 1,462.

In Table 6, the student's $t$-test is used to compare the mean of the variable of interest for Born Global and Gradual Global firms. The distribution of most variables that are used in this study, such as the variety of exported products and the number of exporting 
destinations is substantially skewed towards small numbers. For this reason, I use the natural logs rather than the original raw values of the continuous variables in my analyses.

Table 6 Comparison of the initial conditions between Born Global and Gradual Global firms

\begin{tabular}{|c|c|c|c|c|c|c|}
\hline \multicolumn{2}{|l|}{ Variables } & \multicolumn{2}{|c|}{ Born Global } & \multicolumn{2}{|c|}{$\begin{array}{l}\text { Gradual } \\
\text { Global }\end{array}$} & \multirow{2}{*}{$\begin{array}{l}\text { t-test } \\
0.0000 \\
\end{array}$} \\
\hline \multirow[t]{2}{*}{ Initial Size } & $=\log ($ revenue $)$ & -1.25 & $(1.17)$ & -0.84 & $(1.08)$ & \\
\hline & $=\log \left(\right.$ employees $\left._{1}\right)$ & 1.87 & $(0.05)$ & 2.41 & $(0.03)$ & 0.0000 \\
\hline $\begin{array}{l}\text { Initial Labor } \\
\text { Productivity }\end{array}$ & $=\log ($ revenue $/$ employ & 10.01 & $(0.67)$ & 11.13 & $(0.65)$ & 0.0000 \\
\hline $\begin{array}{l}\text { Initial Wage } \\
\text { Rates }\end{array}$ & $=\log \left(\right.$ payroll $/$ employee $\left._{1}\right)$ & 3.10 & $(0.50)$ & 3.20 & $(0.47)$ & 0.0000 \\
\hline \multirow{3}{*}{$\begin{array}{l}\text { Initial Export } \\
\text { Market } \\
\text { Commitment }\end{array}$} & $=\log \left(\right.$ Exports $\left._{e}\right)$ & -1.72 & $(1.33)$ & -3.09 & $(1.37)$ & 0.0000 \\
\hline & $=\log \left(\right.$ destinations $\left._{e}\right)$ & 0.13 & $(0.39)$ & 0.09 & $(0.31)$ & 0.0082 \\
\hline & $=\log \left(\operatorname{products}_{e}\right)$ & 0.79 & $(0.74)$ & 0.52 & $(0.64)$ & 0.0000 \\
\hline \multicolumn{2}{|l|}{ ICT (\%) } & 6.84 & $(25.27)$ & 7.73 & $(26.71)$ & 0.2582 \\
\hline \multicolumn{2}{|c|}{ Foreign-owned (\%) } & 1.21 & $(10.93)$ & 1.85 & $(13.47)$ & 0.1649 \\
\hline
\end{tabular}

Notes: Value of means is reported in this table, value of standard deviations is reported in parentheses. Value of two-tail t-test, $\operatorname{Pr}(|\mathrm{T}|>|t|)$, is reported in the last column. Variables 'employees', 'payroll per employee', and 'revenue per employee' are estimated in the first year a firm started its business; variables 'exports', 'products', and 'destinations' are estimated in the first year a firm started to export.

Results from Table 6 suggest that Born Global and Gradual Global firms are associated with very different attributes. Compared to Gradual Global firms, Born Global firms (1) are smaller both in terms of number of employees and revenues, (2) have lower revenue per employee, (3) have lower payroll per employee, (4) are more committed to the export market since they have a higher value of exports, number of export destinations, and variety of exported products, and (5) are not significantly different when it comes to the probability of being foreign-owned or belonging to the ICT sector. 
Would the attributes of the Born Globals change if I adopted different numerical thresholds? For example, I could specify a firm as a Born Global if it has started to export within two years of its inception and has exported no less than $50 \%$ of its revenue. To address this concern, Table 11 in the Appendix delivers a detailed investigation on the attributes of firms that are grouped by different thresholds of export start-up age and initial export intensity.

In Table 11-B1, firms are grouped by their export start-up age and initial export intensity as in Table 10. However, both of these two measurements are divided into five rather than two sub-groups. Specifically, the measurement 'export start-up age' is grouped into one year old, two years old, three years old, four years old, and five or more than five years old; the measurement 'initial export intensity' is grouped into $50 \%-100 \%, 25 \%$ $50 \%, 12.5 \%-25 \%, 6.25 \%-12.5 \%$, and $0 \%-6.25 \%$. Preferably, I would like to group firms' initial export intensity into smaller groups, such as $90 \%-100 \%, 80 \%-90 \%, \ldots, 10 \%-20 \%$, and $0 \%-10 \%$. Due to confidentiality issues with regards to the use of data by Statistics Canada, I selected the above numerical thresholds so that the minimum number of firms in each group is ten (see Table 11-B1 for the number of firms in each group). The results from Table $11-\mathrm{B} 2$ to $11-\mathrm{B} 10$ are qualitatively similar to my previous results in Table 10. Therefore, my conclusion is that the attributes of Born Global and Gradual Global firms will not be drastically affected by adopting different numerical thresholds. 


\subsubsection{The Characteristics of Born Global and Gradual Global Firms at their}

\section{Inception}

Table 7 presents key results for the internationalization process choice model, estimated by a probit model ${ }^{18}$. The details of the estimated results are reported in Table 12 in the Appendix. The coefficients in Table 7 show the effects of the explanatory variables on the marginal utility of the Born Global process relative to the Gradual Global internationalization process. The statistical significance of a coefficient indicates the extent to which the corresponding explanatory variable affects the marginal utility of the Born Global process relative to the Gradual Global internationalization process.

\section{Table 7 Probit regression results: What becomes of Born Global?}

(Dependent Variables: $\mathrm{BG}=1$ if a firm is classified as a Born Global and $\mathrm{BG}=0$ otherwise.)

\begin{tabular}{|c|c|c|}
\hline Variables & Coefficient & Std. Err. \\
\hline $\begin{array}{l}\text { Initial Size } \\
=\log (\text { employees })\end{array}$ & $-0.2812 * * *$ & $(0.0311)$ \\
\hline $\begin{array}{l}\text { Initial Labor Productivity } \\
=\log \left(\text { revenue } / \text { employee }{ }_{1}\right)\end{array}$ & $-0.2644 * * *$ & $(0.0654)$ \\
\hline $\begin{array}{l}\text { Initial Wage Rates } \\
=\log \left(\text { payroll } / \text { employee }_{1}\right)\end{array}$ & -0.1318 & $(0.0900)$ \\
\hline ICT & $-0.3041 *$ & $(0.1720)$ \\
\hline Foreign-owned & 0.2034 & $(0.2851)$ \\
\hline \multicolumn{3}{|l|}{ Cohort (reference: 1997) } \\
\hline 1998 & 0.1051 & $(0.1117)$ \\
\hline 1999 & $0.3186^{* * *}$ & $(0.1112)$ \\
\hline 2000 & $0.3347 * * *$ & $(0.1200)$ \\
\hline 2001 & $0.4426 * * *$ & $(0.1168)$ \\
\hline 2002 & $0.6911 * * *$ & $(0.1298)$ \\
\hline 2003 & $0.9951 * * *$ & $(0.1505)$ \\
\hline 2004 & $1.0795 * * *$ & $(0.2078)$ \\
\hline Sector dummies & \multicolumn{2}{|l|}{ yes } \\
\hline Province dummies & \multicolumn{2}{|l|}{ yes } \\
\hline Observations & \multicolumn{2}{|l|}{1959} \\
\hline
\end{tabular}

${ }^{18}$ In unreported regressions, I included both the pobit model and the logit model, and conducted a normality test. The results of the logit model are very similar to those of the probit model. 


\begin{tabular}{|l|l|}
\hline Log likelihood & -990.09171 \\
\hline LR chi2 & 231.20 \\
\hline Pseudo R2 & 0.1045 \\
\hline Predicted Probability & $0.2537(0.4352)$ \\
\hline Observed Probability & $0.2557(0.1506)$ \\
\hline
\end{tabular}

Notes: $N=1959$. The complete results of Table 7 are reported in Table 12 in the Appendix. Value of standard errors is reported in parentheses. $* * *, * *$ and $*$ indicate statistical significant at the $1 \%, 5 \%$ and $10 \%$ levels, respectively.

The results from Table 7 suggest that belonging to the ICT sector has a negative effect on a firm's choice of internationalization process. This result seems puzzling, since numerous studies (for example, De La Torre \& Moxon, 2001; Dunning \& Wymbs, 2001) have documented the role of ICT in promoting the emergence of the Born Global phenomenon. However, a study by Baldwin and Gu (2003) indicated that due to slower technological progress within the high-technology sector in Canada compared with that in the U.S. between 1996 and 2003, productivity growth declined among Canadian manufacturers but increased remarkably among their U.S. counterparts. Therefore, the negative effect of the ICT sector on a Canadian manufacture's choice on the Born Global process is consistent with the findings by Baldwin and $\mathrm{Gu}$.

The results in Table 7 suggest that, everything else being equal, the smaller (in terms of number of employees) the firm at the founding of the company, the more likely it will choose the Born Global internationalization process. This result is consistent with Cavusgil et al. (2008, p15)'s argument that smaller firms are more adaptable and have quicker response times to new ideas and technologies. Consequently, smaller firms are more likely to export intensively at the founding of the company.

I would have preferred to have chosen a measure of total factor productivity (TFP) to compare the efficiency of Born Global and Gradual Global firms. Unfortunately, the 
available data does not permit construction of a TFP index. Hence, I used the apparent labor productivity (APT), revenue per worker, as a proxy for firms' efficiency. The results from Table 7 suggest that everything else being equal, the less productive the firm at the founding of the company, the more likely it will choose the Born Global internationalization process.

Furthermore, the results in Table 7 suggest that, everything else being equal, the later the firm starts its business, the more likely it will choose the Born Global internationalization process. This finding is consistent with previous studies that use macro factors, such as shrinking transportation and communication costs (Holstein, 1992) and "improvements in global telecommunications and transport networks, combined with increasingly liberalized global trading regimes" (Fan and Phan, 2007, p1113) as an explanation of the emergence of the Born Global phenomenon. This finding may also suggest that Born Global has become a popular internationalization process among small and medium-sized manufactures in Canada.

According to the estimated coefficients of the probit model, the mean value of Canadian newly established small and medium-sized manufacturers' predicted probability of adopting the Born Global internationalization process is $25.57 \%$ while the mean value of the observed probability is $25.37 \%$. This may suggest that my model of internationalization process choice fits well and has a high power of prediction. Second, the later a firm starts its business, the more likely it will choose the Born Global internationalization process. 


\subsubsection{The Effect of Born Global Process on the Exit of New Exporters}

Plotted in Figure 5, the survival rate at each moment indicates the probability that a new exporter will keep exporting at any time up until that moment. Figure 5 shows that the probability of survival in the export market of Gradual Global firms is slightly higher than that of Born Global firms, although the initial difference decreases over time.

\section{Figure $5 \quad$ Exit of new exporters}

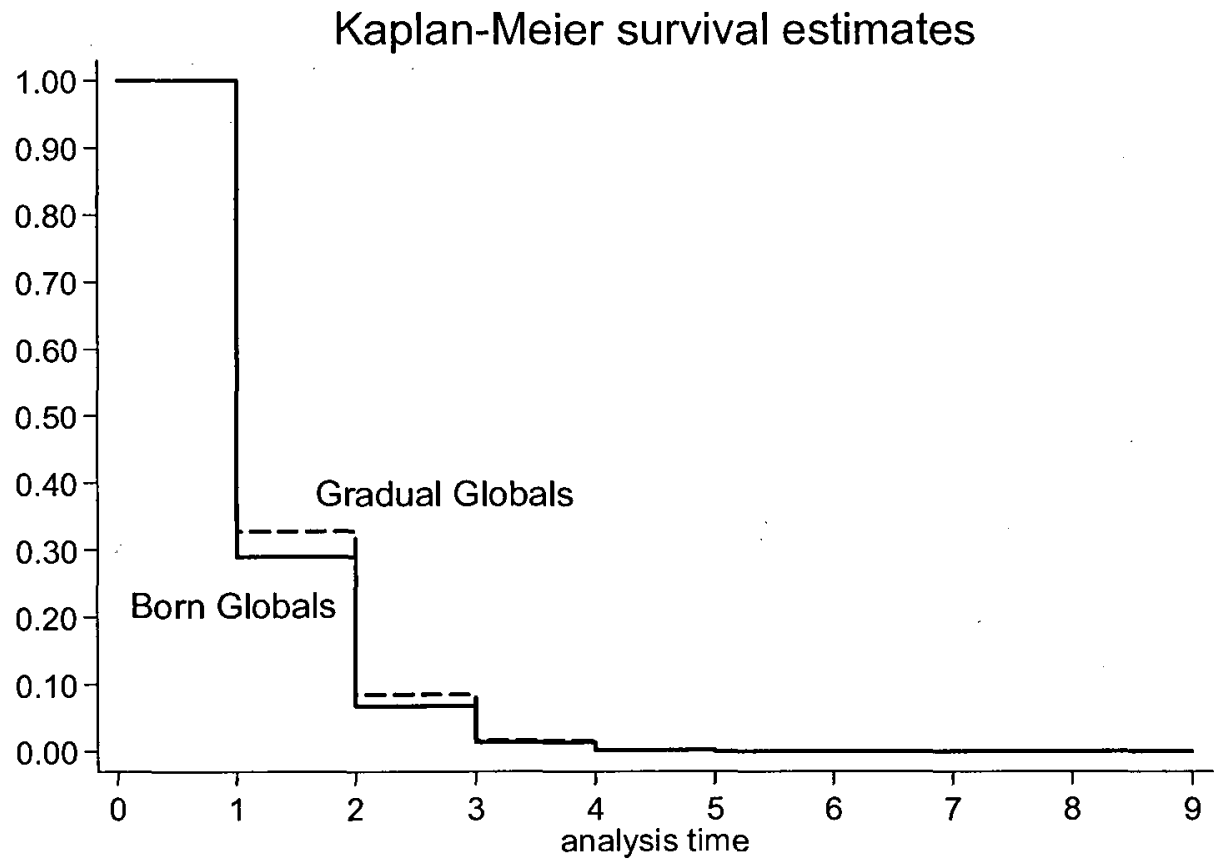

The perception that Born Global firms have a lower survivability in the export market, as shown in Table 7, is based on the fact that Born Global firms were smaller and less productive at the founding of the company than Gradual Global firms. As such, the lower survivability in the export market of Born Global firms could be a result of their poor initial conditions. A recent study by Zettinig and Benson-Rea (2008) proposed a coevolutionary approach to explain the mechanisms that might secure the long-run survival and growth of Born Globals. The authors argued that initial conditions of a firm, such as 
its ability to explore new knowledge, are essential to its long-run survival and growth. Therefore, it is critically important to control for the founding conditions of firms to assess the ceteris paribus effect of the Born Global internationalization process on the survivability of firms.

The key results of estimating several specifications of the hazard model are reported in Table 8. The details of the estimated results are reported in Table 13 in the Appendix. The coefficients in Table 8 show the effect of the explanatory variables on the survivability of firms. A positive coefficient indicates increased risk, and a negative coefficient indicates a reduced risk. The statistical significance of a coefficient indicates the extent to which the corresponding explanatory variable affects the survivability of firms.

In order to demonstrate the importance of taking into account the internationalization process on empirical estimates on the survivability of firms in the export market, I reported the results of a regressions with and without $B G_{i}$ in column 2 and column 1 respectively. To demonstrate the importance of taking into account the endogeneity of empirical estimates, I reported the results of a regression with $\hat{B G_{i}}$, the estimated probability for firm $i$ to choose the Born Global internationalization process that is estimated from Table 8 in column 3. The regression results with the Split-Sample Instrumental Variable (SSIV) methodology is reported in column 4. 
Table 8 The effect of Born Global process on the export market survivability of new exporters: regression results from the Cox proportional hazard model

\begin{tabular}{|c|c|c|c|c|}
\hline & All Firms & All Firms & $\begin{array}{l}\text { All Firms } \\
\text { (2-stage) }\end{array}$ & $\begin{array}{l}\text { All Firms } \\
\text { (SSIV) }\end{array}$ \\
\hline & 1 & 2 & 3 & 4 \\
\hline \multirow[t]{2}{*}{ BG } & & $0.0578 * * *$ & -0.1582 & -0.0315 \\
\hline & & $(0.0222)$ & $(0.1319)$ & $(0.0604$ \\
\hline \multirow[t]{2}{*}{ ICT } & -0.0228 & -0.0202 & -0.0085 & -0.0733 \\
\hline & $(0.0476)$ & $(0.0475)$ & $(0.0491)$ & $(0.0721$ \\
\hline \multirow[t]{2}{*}{ Foreign-owned } & -0.0165 & -0.0135 & -0.0067 & -0.0273 \\
\hline & $(0.0351)$ & $(0.0350)$ & $(0.0359)$ & $(0.0629$ \\
\hline \multirow[t]{2}{*}{ U.S. first } & -0.0113 & $-0.0120 * * *$ & -0.0113 & -0.0015 \\
\hline & $(0.0233)$ & $(0.0019)$ & $(0.0233)$ & $(0.0324$ \\
\hline Initial Size & $-0.0287 * *$ & $-0.0331 * * *$ & $-0.0418 * * *$ & -0.0192 \\
\hline$=\log \left(\right.$ employee $\left._{1}\right)$ & $(0.0116)$ & $(0.0118)$ & $(0.0163)$ & $(0.0252)$ \\
\hline Initial Labor & $-0.0119 * * *$ & $-0.0144 * * *$ & $-0.0301 * * *$ & $-0.0321 * * *$ \\
\hline Productivity & $(0.0043)$ & $(0.0007)$ & $(0.0036)$ & $(0.0028)$ \\
\hline \multicolumn{5}{|l|}{$=\log \left(\right.$ revenue $\left._{\text {employee }}\right)$} \\
\hline Initial Wage Rates & 0.0547 * & $0.0551 *$ & $0.0617 *$ & 0.0710 \\
\hline$=\log \left(\right.$ payroll $/$ employee $\left._{1}\right)$ & $(0.0316)$ & $(0.0315)$ & $(0.0324)$ & $(0.0490)$ \\
\hline Size & -0.0026 & $-0.0027 * * *$ & $-0.0024 * * *$ & -0.0058 \\
\hline$=\log \left(\right.$ employee $\left._{t}\right)$ & $(0.0025)$ & $(0.0007)$ & $(0.0003)$ & $(0.0040)$ \\
\hline Labor Productivity & $-0.0125 * * *$ & $-0.0116 * * *$ & $-0.0125 * * *$ & $-0.0046 * *$ \\
\hline$=\log \left(\right.$ revenue $\left._{\text {employee }}\right)$ & $(0.0044)$ & $(0.0044)$ & $(0.0043)$ & $(0.0021)$ \\
\hline Wage Rates & $0.0207 * * *$ & $0.0200 * *$ & $0.0206 * * *$ & 0.0126 \\
\hline$=\log \left({\left.\text { payroll } / \text { employee }_{t}\right)}\right.$ & $(0.0072)$ & $(0.0070)$ & $(0.0072)$ & $(0.0098)$ \\
\hline Products & $-0.0044^{* *}$ & $-0.0035 * * *$ & $-0.0041 *$ & $-0.0057 *$ \\
\hline$=\log \left(\right.$ products $\left._{t}\right)$ & $(0.0023)$ & $(0.0006)$ & $(0.0023)$ & $(0.0034)$ \\
\hline \multirow[t]{2}{*}{ Destinations } & $-0.0039 * *$ & $-0.0036 *$ & $-0.0039 *$ & $-0.0019 *$ \\
\hline & $(0.0020)$ & $(0.0020)$ & $(0.0020)$ & $(0.0009)$ \\
\hline
\end{tabular}




\begin{tabular}{|c|c|c|c|c|}
\hline \multicolumn{5}{|l|}{$=\log \left(\right.$ destinations $\left._{t}\right)$} \\
\hline \multirow[t]{2}{*}{ Re-enter } & $-0.2489 * * *$ & $-0.2471 * * *$ & $-0.2303 * * *$ & -0.0955 \\
\hline & $(0.066) 1$ & $(0.0679)$ & $(0.0685)$ & $(0.0718)$ \\
\hline Sector dummies & yes & yes & yes & yes \\
\hline Province dummies & yes & yes & yes & yes \\
\hline Cohort dummies & yes & yes & yes & yes \\
\hline Wald chi2 & 1170.48 & 1288.92 & 1353.92 & 202.02 \\
\hline Observation & 7287 & 7287 & 7287 & 3605 \\
\hline Firms & 2072 & 2072 & 2072 & 958 \\
\hline Log pseudo likelihood & -34169.979 & -34168.423 & -34167.766 & -14881.442 \\
\hline
\end{tabular}

Table 8 shows the pseudo-likelihood ratio (PLR) test statistics of models with different specifications. Improvement is recorded if a firm's internationalization process is included in the model, since the PLR statistics increase from -34169.979 to -34168.423 as we move from column 1 to column 2. Meanwhile, the estimated coefficients do not change much. Further improvement is recorded when the selectivity bias is corrected, since the PLR statistics increase from -34168.423 to -34167.766 as we moved from column 2 to column 3 .

At the top of Table 8 , the coefficient 0.0578 of variable BG (column 2) indicates that Born Global firms experience a hazard rate which is about $5.95 \%$ (i.e., $e^{0.0578}-1$ ) higher than that of Gradual Global firms, controlling for a wide range of factors that might affect the survivability of firms in the export market. Such evidence supports Hypothesis 1 , that 
is, everything else being equal, Born Globals have a higher probability of exit from exporting than Gradual Globals.

When the estimates are corrected for the selectivity bias, shown in column 3 , the magnitude of this result changes, and the statistical significance of this result vanishes. I examined the robustness of my results by applying the SSIV estimation. This result is consistent as the SSIV is applied, shown in column 4. As such, the Born Global internationalization process no longer has a negative effect on the survivability of firms in the export market. This result supports Hypothesis 2, and suggests that estimations from models that do not account for endogeneity of internationalization strategy choice may lead to incorrect conclusions.

\subsubsection{Exit from Exporting of Born Global and Gradual Global Firms}

In order to investigate the determinants on the survivability of Born Global and Gradual Global firms in the export market, I reported the results of separate regressions for Born Global and Gradual Global firms in Table 9 column 5 and column 6 respectively. It appears from Table 9 that Born Global and Gradual Global firms have rather different determinants of exit from exporting. Table 9 column 5 shows, for Born Globals, a decrease in the initial and current wage rates of the firm, and a decrease in the variety of products exported by the firm, decrease its hazard rate of exit, and thus, increase its survivability in the export market. Table 9 column 6 shows, for Gradual Globals, a decrease in the initial size and current labor productivity of the firm, an increase in the variety of products exported, an increase in the export destinations. It also shows that choosing the U.S. as the firm's first export destination, decreases its hazard rate of exit, and thus, increases its survivability in the export market. 
Table 9

The determinants of exit from exporting: Born Globals and Gradual

Globals

\begin{tabular}{|c|c|c|c|}
\hline & & Born Global & Gradual Global \\
\hline & & 5 & 6 \\
\hline \multirow[t]{2}{*}{1} & ICT & 0.0590 & -0.0609 \\
\hline & & $(0.0867)$ & $(0.0551)$ \\
\hline \multirow[t]{2}{*}{2} & Foreign-owned & -0.0679 & -0.0056 \\
\hline & & $(0.0646)$ & $(0.0457)$ \\
\hline \multirow[t]{2}{*}{3} & U.S. first & -0.0177 & $-0.0021 * *$ \\
\hline & & $(0.0462)$ & $(0.0010)$ \\
\hline \multirow[t]{2}{*}{4} & Initial Size & -0.0210 & $-0.0469 * * *$ \\
\hline & $=\log \left(\right.$ employee $\left._{1}\right)$ & $(0.0194)$ & $(0.0150)$ \\
\hline \multirow[t]{2}{*}{5} & Initial Labor Productivity & -0.0424 & -0.0095 \\
\hline & $=\log \left(\right.$ revenue $\left._{\text {employee }}\right)$ & $(0.0238)$ & $(0.0220)$ \\
\hline \multirow[t]{2}{*}{6} & Initial Wage Rates & $0.0749 * * *$ & 0.0533 \\
\hline & $=\log \left({\left.\text { payroll } / \text { employee }_{1}\right)}\right.$ & $(0.0021)$ & $(0.0392)$ \\
\hline \multirow[t]{2}{*}{7} & Size & -0.0044 & -0.0018 \\
\hline & $=\log \left(\right.$ employee $\left._{t}\right)$ & $(0.0257)$ & $(0.0033)$ \\
\hline \multirow[t]{2}{*}{8} & Labor Productivity & -0.0087 & $-0.0122 * *$ \\
\hline & $=\log \left(\right.$ revenue $\left._{\text {employee }}\right)$ & $(0.0066)$ & $(0.0057)$ \\
\hline \multirow[t]{2}{*}{9} & Wage Rates & $0.0202 * *$ & 0.0128 \\
\hline & $=\log \left(\right.$ payroll $/$ employee $\left._{t}\right)$ & $(0.0094)$ & $(0.0101)$ \\
\hline \multirow[t]{2}{*}{10} & Products & $0.0071^{*}$ & $-0.0023 * * *$ \\
\hline & $=\log \left(\right.$ products $\left._{t}\right)$ & $(0.0036)$ & $(0.0007)$ \\
\hline \multirow[t]{2}{*}{11} & Destinations & -0.0034 & $-0.0074 * * *$ \\
\hline & $=\log \left(\right.$ destinations $\left._{t}\right)$ & $(0.0035)$ & $(0.0029)$ \\
\hline \multirow[t]{2}{*}{12} & Re-enter & $-0.5480 * *$ & $-0.1924 * * *$ \\
\hline & & $(0.2526)$ & $(0.0538)$ \\
\hline 13 & Sector dummies & yes & yes \\
\hline 14 & Province dummies & yes & yes \\
\hline 15 & Cohort dummies & yes & yes \\
\hline 16 & Wald chi2 & 86.88 & 913.71 \\
\hline 17 & Observation & 2125 & 5162 \\
\hline 18 & Firms & 521 & 1551 \\
\hline 19 & Log pseudo likelihood & -8290.7449 & -22829.628 \\
\hline
\end{tabular}

Notes: Robust standard errors (corrected for clustering at the firm level) are in parentheses. $* * *, * *$ and $*$ indicate statistical significant at the $1 \%, 5 \%$ and $10 \%$ levels, respectively. 
I found that current labor productivity has a negative effect on the hazard rate of exit, and thus, a positive effect on the survivability of Gradual Global firms in the export market. This result is consistent with the predictions from the Melitz (2003) model. However, neither initial nor current labor productivity has a statistically significant effect on the survivability of Born Global firms. Therefore, Hypothesis $2 \mathrm{a}$, that more productive firms are more likely to survive in the export market, is partially supported.

Neither initial nor current wage rates have a statistically significant effect on the survivability of Gradual Global firms in the export market. Moreover, counter to expectations, both initial and current wage rates have a positive effect on the hazard rate of exiting for Born Global firms. Therefore, Hypothesis $2 b$, that firms pay higher wage are more likely to survive in the export market, is not supported. This result seems puzzling, because one would expect that firms that are able to survive in the export market are usually good firms that are able to pay higher wages to their employees. However, these results are consistent with the predictions from Albornoz et al. (2009) if we consider wage as a proxy for labor costs instead of labor productivity.

Specifically, building on the original Melitz model, Albornoz et al. (2009) developed a mechanism that export profitability is uncertain for a firm before it starts exporting. Everything else being equal, both lower labor costs and higher labor productivity will lead to a higher level of profitability. Firms with lower labor costs may anticipate a higher level of profitability before they start exporting. Such firms will export intensively at the founding of the company and become Born Globals. Moreover, such firms are able to export continuously if they could maintain their advantage in lower labor costs. On the 
other hand, firms learn about their productivity only after they start exporting. If firms export just to learn about their profit potential, they will export only the minimum necessary for effective learning and become Gradual Globals. Moreover, such firms are able to continue exporting provided they maintain their advantage of high labor productivity.

For Gradual Global firms, both export product diversification and export market diversification have a negative effect on the hazard rate of exit, and thus, a positive effect on the probability of survival in the export market. These results are consistent with the results from Sabuhoro et al. (2006). For Gradual Global firms, however, their export market survivability does not seem to be affected by their export market diversification. Moreover, it appears that export product diversification has a positive effect on the hazard rate of exit for Born Global firms. Therefore, Hypothesis 3a that firms exporting to more destinations are more likely to survive in the export market is partially supported. Similarly, Hypothesis $3 b$ that more product-diversified firms are more likely to survive in the export market is partially supported. Nevertheless, my findings are consistent with a study by Chetty and Campbell-Hunt (2004) on New Zealand firms. Chetty and CampbellHunt showed that Born Global firms are characterized by having a narrow product range and serving a "specialized product for niche markets"; regional firms, on the other hand, have "diversified product range to broad market segments". Therefore, export product and market diversification may not have as much of a positive effect on the export market survivability for Born Global firms as for Gradual Global firms.

Choosing the "easiest" and "closest" market (the U.S.) as the first export destination has a statistically significant negative effect on the hazard of exit of Gradual Global but no 
effect on the hazard of exit of Born Global firms. Hence, both Hypothesis 4a and Hypothesis $4 \mathrm{~b}$ are supported.

The effect of foreign ownership on firms' survivability in the export market will depend mainly on whether the foreign investors seek to establish an exporting platform or to find a new market (Dunning, 1977). Additionally, previous empirical evidence on the economic performance of foreign and domestically owned Canadian establishments (Globerman et al., 1994) showed that foreign-owned Canadian establishments have significantly higher value added per worker and pay higher wages than domestic-owned Canadian establishments. However, such difference disappeared once the authors controlled for factors such as size and capital intensity of the firms. Therefore, it is not surprising to find that foreign ownership has a negative but insignificant effect on the hazard rate of exit for both Born Global and Gradual Global firms.

Finally, my results show that previous export experience has a statistically significant negative effect on the hazard of exit from exporting, and hence, a positive effect on the survival of exporters, regardless of their internationalization process.

I was concerned with the possibility that these results might have been decisively affected by the alternative numerical definition of Born Global firms. Accordingly, I ran the same regressions as above using Knight and Cavusgil (1996)'s definition (three years and 25\% thresholds) on Born Globals. Those results are qualitatively identical to the results reported in Table 8 and Table 9. 


\section{6 Conclusions}

This study seeks to answer the following questions: What is the effect of Born Global process on the survivability of firms in the export market? What are the determinants of survival of Born Global and Gradual Global firms in the export market?

To provide answers to above questions, I analyzed the export market survival patterns of 1,959 newly established small and medium-sized Canadian manufacturers between 1997 and 2005. A firm is classified as a Born Global firm if it begins to export within two years of its inception and exports no less than $25 \%$ of its total revenue during the first year of its export activity; otherwise, a firm is classified as a Gradual Global. The percentage of firms that are classified as Born Global is $25.37 \%$.

After controlling for a wide range of factors that might affect the survivability of firms in the export market, it appears that Born Global process has a significant negative effect on the survivability of firms in the export market. After accounting for the self-selection associated with a firm's choice of internationalization process, however, the Born Global process no longer affects firms' survivability in the export market. These results suggest that the Born Global internationalization process is a strategic choice for a particular group of young firms that appear in my data to be relatively small and less productive at the founding stage of the company. Such firms would have a lower chance of survival in the export market if they have chosen the traditional Gradual Global internationalization process.

My findings suggest that Born Global and Gradual Global firms have very different determinants of exit from exporting. The factors that determine the export market 
survivability of Gradual Globals firms are consistent with previous empirical studies (Harris and Li, 2007; Sabuhoro et al., 2006). These studies show that firms are larger, more productive, export more products, export to more markets, and that choosing the U.S. as the first export destination means a better chance of survival in the export market. Unlike Gradual Global firms, Born Global firms will have a higher survivability in the export market with a decrease in both the variety of products they export and the wages they pay. These results could have important implications for policy-makers in improving the design and targeting of Canada's trade and investment promotion programs. These results also have important implications for researchers in understanding that internationalization is a mixed bag containing different types of firms, who have different advantages and disadvantages in competing in the global export market. 


\section{7 Reference}

Albornoz, F., Calvo, H., Corcos, G., and Ornelas, E. (2009), "Sequential Exporting", working in progress.

Angrist, J. D. and Krueger, A. B. (1995), "Split-Sample Instrumental Variables Estimates of the Returns to Schooling", Journal of Business and Economic Statistics, 13:2, 225-35.

Audretsch, D.B. and Mahmood, T. (1995), "New firm survival: new results using a hazard function", Review of Economics and Statistics 77(1): 97-103.

Baggs, J. (2005), "Firm Survival and Exit in Response to Trade Liberalization" , Canadian Journal of Economics, 38(4): 1364-1383.

Baggs, J., Beaulieu E., and Fung, L. (2009), "Firm Survival, Performance, and Exchange Rates", Canadian Journal of Economics, 41(2).

Baldwin, J.R. and Gorecki, P.K. (1991), "Productivity Growth and the Competitive Process: The Role of Firm and Plant Turnover", In P.A. Geroski and J. Schwalbach. Entry and Market Contestability: An International Comparison. Oxford: Basil Blackwell. 244-56.

Baldwin, J. and Gu W. (2003), "Participation in export markets and productivity performance in Canadian manufacturing", Research Paper No. 011, Statistics Canada Publication, Ottawa.

Beaulieu, E. and Emery J.C. H. (2006), "Stay the course or find a new path? Canada's reliance on the U.S. as an export market." In NAFTA@10, eds. J. M. Curtis and A. Sydor. Ottawa: Minister of Public Works and Government Services.

Bell, J. (1995), "The Internationalization of Small Computer Software Firms", European Journal of Marketing, 29(8), 60-75. 
Bolduc, D., Khalaf, L., and Moyneur, É. (2008), "Identification-robust simulation-based inference in joint discrete/continuous models for energy markets", Computational Statistics \& Data Analysis, 52(6): 3148-3161.

Benito, G. R. G., Pedersen, T., and Petersen, B. (2005), "Export channel dynamics: An empirical investigation." Managerial and Decision Economics 26(3): 159-173.

Bernard, A. B. and Jensen J. B. (1999), "Exceptional exporter performance: cause, effect, or both?" Journal of International Economics 47(1): 1-25.

Bernard, A. B. and Jensen J. B. (2001), "Why Some Firms Export", Working Paper 8349, NBER Working Paper Series.

Bohatyretz, S. and Santarossa B. (2005), "Merchandise Trade Reconciliation Study: Canada-China, 2002 and 2003", Canadian Trade Review, No 3, International Trade Division, Statistics Canada.

Bolduc, Khalaf D., L., and Moyneur E. (2008), "Identification-robust simulation-based inference in joint discrete/continuous models for energy markets", Computational Statistics and Data Analysis, 52(6): 3148-3161.

Boter, H., and Holmquist, C. (1996), "Industry characteristics and internationalization processes in small firms", Journal of Business Venturing, 11: 471-487.

Brush, C. G. (1992), "Factors Motivating Small Companies to Internationalize: the Effect of Firm Age", Unpublished dissertation, Boston University, Boston.

Burger, A., Sabuhoro J., Sydor B., A., and Desjardins S. (2007), "Canada's State of Trade - Trade and Investment Update 2007", Ottawa: Foreign Affairs and International Trade Canada, The Office of the Chief Economist of Foreign Affairs.

Burton, F.N. and Schlegelmilch B.B. (1987), "Profile analyses of non-exporters versus exporters grouped by export involvement", Management International Review. 27(1): 3849.

Byrd, C. (2005), "Foreign Control of Canada's Merchandise Exports, 2002", Analytical Paper No. 004, Statistics Canada Publication, Ottawa. 
Cavusgil, S. T., Knight, G., and Riesenberger, J. R. (2008), International Business: Strategy, Management, and the New Realities, ISBN-10: 0131738607.

Chetty S. and Campbell-Hunt, C. (2004), "A strategic approach to internationalisation: A traditional versus a 'born-global' approach", Journal of International Marketing, Vol. 12 No.1, p 57-81.

Clerides, S., Lach, S., and Tybout, J. (1998), "Is learning by exporting important? Microdynamic evidence from Colombia, Mexico, and Morocoo", Quarterly Journal of Economics 113(3), p 903-947.

Coviello, N. E. and Jones, M. V. (2004), "Methodological issues in international entrepreneurship research". Journal of Business Venturing, 19(4), 485-508.

Cox, D.R. (1972), Regression Models and Life Tables, Journal of the Royal Statistical Society, 34, 187-220.

De La Torre, J., and Moxon, R. W. (2001), "E-commerce and global business: The impact of the information and communication technology revolution on the conduct of international business". Journal of International Business Studies, 32(4): 12-25.

Delgado, M.A., Farinas J.C., and Ruano S. (2002), "Firm productivity and export markets: a non-parametric approach", Journal of International Economics 57, p397-422.

Dunning, J. H. (1977), "Trade, location and economic activity and the multinational enterprise: A search for an eclectic approach", In the international allocation of economic activity. London: MacMillan.

Dunning, J., and Wymbs, C. (2001), "The challenge of electronic markets for international business theory", International Journal of the Economics of Business, 8(2): $123-145$.

Eaton, J., Eslava, Kugler M., M., and Tybout, J. (2007), "Export Dynamics in Colombia: Firm-Level Evidence", NBER Working Paper Series, working paper 13531. 
Eaton, J., Kortum S. and Kramarz. F. (2008), "An Anatomy of International Trade: Evidence from French Firms", NBER Working Paper 14610.

Fan, T. and Phan, P. (2007), "International new ventures: revisiting the influences behind the 'born-global' firm”, Journal of International Business Studies, 38: 1113-1131.

Florida, R. and Stolarick, K. (2006), "Creativity, connections and innovation: A study of linkages in the Montréal region", Environment and Planning A, vol. 38, n10: 1799-1817. Forsgren, M. and Johanson, J. (1975), Internationall företagsekonomi. Stockholm: Norstedts.

Freeman J, Carroll G.R., and Hannan, M.T. (1983), "The liability of newness, age dependence and organizational death rates", American Sociological Review, Vol. 48 pp.692-710.

Gabrielsson, M, Kirpalani, M., Dimitratos, P., Solberg, C., and Zuchella, A. (2008), "Conceptualizations to Advance Born Global Definition: A Research Note", Global Business Review, Vol. 9, No. 1, 45-50.

Geroski, P. A. (1995), "What Do We Know about Entry?" International Journal of Industrial Organization, 13, 421-440.

Globerman, S., Ries, J. C., and Vertinsky, I. (1994), "The economic performance of foreign affiliates in Canada", Canadian Journal of Economics, Vol. XXVII, No. 1, pp. 143-156.

Harris R and Q., Li (2007), "Determinants of exit from exporting", report to UKTI.

Head, K. (2007), "Engage the US, forget the rest? Comments", in A Canadian Priorities Agenda: Policies to Improve Economic and Social Well-Being, eds. J. Leonard, C. Ragan, and F. St-Hilaire. McGill-Queen's University Press.

Holstein, W. J. (1992), "Little companies, big exports". Business Week,13(April): 70-72.

Huynh, K., Petrunia R., and Voia, M., "The Impact of Initial Financial State on Firm Duration across Entry Cohorts", forthcoming, Journal of Industrial Economics. 
Isgut, A.E. (2001), "What's different about exporters? Evidence from Colombia manufacturing", Journal of Development Economics 37(5), p 57-82.

Jiang, S. (2007), "Immigration, Information, and Trade Margins", Working Papers from Department of Economics, University of Calgary, No 2007-16.

Johanson, J. and Wiedersheim-Paul, F. (1975), "The Internationalization Process of the Firm-Four Swedish Case Studies", Journal of Management Studies, Vol. 12, p. 305-322.

Johanson, J. and Vahlne, J.E. (1990), "The mechanism of internationalization", International Marketing Review, Vol. 7, No. 4, pp. 11 -24.

Jolly, V. K., Alahuhta, M., and Jeannet, J. P. (1992), "Challenging the Incumbents: How High Technology Start-Ups Compete Globally", Journal of Strategic Change 1: 71-82.

Judge G., Hill, C., Griffiths, W., and Lee, T. (1985), Introduction to Theory and Practice of Econometrics. New York: John Wiley.

Krugman, P.R. (1979), "Increasing returns, monopolistic competition, and international Trade." Journal of International Economics 9: 469-479.

Keeble, D., Lawson, C., Smith, H. L., Moore, B., and Wilkinson, F. (1998), "Internationalization processes, networking and local embeddedness in technologyintensive small firms". Small Business Economics, 11: 327-342.

Keupp, M. M. and Gassmann, O. (2009), "The past and the future of international entrepreneurship: A review and suggestions for developing the field", Journal of Management, 35(Annual Review Issue 2009), 600-633.

Knight, G.A. (1997), "Emerging paradigm for international marketing: the Born Global firm", $\mathrm{PhD}$ thesis.

Knight, G. A. and Cavusgil, S. T. (1996), "The born global firm: A challenge to traditional internationalization theory", Advances in International Marketing, 8: 11-26.

Krugman, P.R. (1979), "Increasing returns, monopolistic competition, and international Trade", Journal of International Economics 9, 469-479. 
Lam W. L. and White, P. L. (1999), "An adaptive choice model of the internationalization process", The International Journal of Organizational Analysis, Vol. 7, No. 2, April, p.105-34.

Lancaster, T. (1990), The econometric analysis of transition data. Cambridge University Press, Cambridge.

Mata, J., Portugal P., and Guimaraes P. (1995), "The Survival of New Plants, Start-up Conditions and Post-Entry Evolution", International Journal of Industrial Organization, $13(4), 459-481$.

Masten, S.E. (1993), "Transaction costs, mistakes and performance: assessing the importance of governance", Managerial and Decision Economics 14(2): 119-129.

Madsen, T. K. and Servais, P., (1997), "The Internationalization of Born Globals: an Evolutionary Process?", International Business Review, Vol. 6, pp. 561-583.

Madsen, T. K., Rasmussen, E. S., and Servais, P. (2000), "Differences and similarities between born globals and types of exporters", Advances in International Marketing, 10: 247-265.

Mayer, T. and Ottaviano, G. I.P., (2007). "The Happy Few: The internationalisation of European firms. New facts based on firm-level evidence", Bruegel blueprint series, Volume 3, 2007.

McDougall, P. P. and Oviatt, B. M. (2000), "International Entrepreneurship: The Intersection of Two Research Paths", Academy of Management Journal, 43 (5), 902-906.

McKinsey and Co. (1993), "Emerging Exporters: Australia's High Value-Added Manufacturing Exporters", Melbourne: McKinseyand Co., Australian Manufacturing Council.

Meckl, R. and Schramm, R. (2005), "Empirical evidence for a theory of international new ventures", Jenaer Schriften zur Wirtschaftswissenschaft, Nr. 06. 
Melitz, M.J. (2003), "The Impact of Trade on Intra-Industry Reallocations and Aggregate Industry Productivity". Econometrica, 71(6), 1695-1725.

Moen, Ø. and Servais, P. (2002), "Born Global or Gradual Global? Examining the Export Behavior of Small and Medium-Sized Enterprises," Journal of International Marketing, $10(3), 49-72$.

Mudambi, R. and Zahra, S.A. (2007), "The survival of international new ventures", Journal of International Business Studies, 38, 333-352

Oviatt, B. M. and McDougall, P. P. (1994), "Toward a Theory of International New Ventures", Journal of International Business Studies 24, 45-64.

Oviatt, B. M. and McDougall, P. P. (1997), "Challenges for internationalization process theory: The case of international new ventures", Management International Review, 37: $85-99$.

Rao, S. and Tang J. (2000), "Are Canadian-Controlled Manufacturing Firms Less Productive than Their Foreign-Controlled Counterparts?" Industry Canada Research Publications Program, Working Paper Number 31.

Rennie, M. W. (1993), “Born Global”, McKinsey Quarterly 4, 45-52.

Ruane, F. and Sutherland J. (2004), "Ownership and Export Characteristics of Irish Manufacturing Performance", IIIS Discussion Paper No.32.

Shapiro, D. M. (1981), Foreign and Domestic Firms in Canada: A Comparative Study of Financial Structure and Performance. Butterworth \& Co. (Canada) Ltd.

Sabuhoro J. B, Larue, B., and Gervais, Y. (2006), "Factors determining the success or failure of Canadian establishments on foreign markets: a survival analysis approach", The Internationals Trade Journal, Volume XX, No. 1, p33-73.

Sapienza, H. J., Autio, E., George, G., Zahra, S. A. (2006), "A Capabilities Perspective on the. Effects of Early Internationalization on Firm Survival and Growth", Academy of Management Review, Vol. 31, Issue 4, p 914-933. 
Shrader, R. C. (2001), "Collaboration and performance in foreign markets: The case of young high-technology manufacturing firms", Academy of Management Journal, 44: 4560 .

Shaver, M. (1998), “Accounting for endogeneity when assessing strategy performance: Does entry mode choice affect”. Management Science, 44 (4): 571-585.

Stinchcome, A.L. (1965), "Social Structure and Organizations", in J. March (ed.) Handbook of Organizations, Rand McNally: Chicago, IL, pp: 142-193.

Ursic, M.L. and Czinkota, M.R. (1984), "An experience curve explanation of export expansion", Journal of Business Research, Vol. 12 pp.159-68.

Wagner, J. (2003), “Are Nascent Entrepreneurs Jacks-of-All-Trades? A Test of Lazear's Theory of Entrepreneurship with German Data", IZA Discussion Papers 911, Institute for the Study of Labor (IZA).

Wei, Y., Liu B., and Liu X. (2005), "Entry modes of foreign direct investment in China: A multinomial logit approach", Journal of Business Research, 58(11): 1495-1505.

Welch, L. S. and Luostarinen, R. (1988), "Internationalisation: evolution of a concept", Journal of General Management, Vol:34, Winter, p.34-57.

Zahra, S.A., Ireland, R.D., and Hitt, M.A. (2000), "International expansion by new. venture firms: international diversity, mode of market entry, technological learning, and performance", Academy of Management Journal, Vol. 43 No. 5, p. 925-50.

Zahra, S. A. (2005), "A theory of international new ventures: a decade of research", Journal of International Business Studies, Volume 36, Number 1, January 2005 , pp. 2028(9).

Zettinig, P. and Benson-Rea, M. (2008), "What becomes of International New Ventures? A coevolutionary approach", European Management Journal, Vol. 26(6), p 354-365. 


\section{8 Appendix}

\subsubsection{Variables of Interest}

Table $10 \quad$ Variable definitions, descriptive statistics, and sources

\begin{tabular}{|c|c|c|c|c|c|c|}
\hline Name & Definition & Mean & S.D. & Max & Min & Source \\
\hline BEBY & $\begin{array}{l}\text { the first year a firm appears } \\
\text { in the BR database }\end{array}$ & 1999.43 & 1.95 & 1997 & 2004 & $\mathrm{BR}$ \\
\hline ERBY & $\begin{array}{l}\text { the first year a firm appears } \\
\text { in the ER database }\end{array}$ & 2000.75 & 2.00 & 1997 & 2004 & ER \\
\hline ERDY & $\begin{array}{l}\text { the last year a firm appears } \\
\text { in the BR database }\end{array}$ & 2004.35 & 1.28 & 1997 & 2005 & ER \\
\hline Duration & Spell duration in years & 3.38 & 2.01 & 1 & 9 & ER \\
\hline Censor & $\begin{array}{l}=1 \text { if the firm exports in } \\
2005\end{array}$ & 0.71 & 0.21 & 0 & 1 & ER \\
\hline Re-enter & $\begin{array}{l}=1 \text { if the firm re-enters the } \\
\text { export market }\end{array}$ & 0.3 & 0.16 & 0 & 1 & ER \\
\hline ExAge & $\begin{array}{l}=E R B Y-B R B Y+1, \text { the firm's } \\
\text { export start-up age }\end{array}$ & 1.32 & 1.59 & 0 & 7 & $\begin{array}{l}\mathrm{ER}, \\
\mathrm{BR}\end{array}$ \\
\hline Exports & $\begin{array}{l}\text { Annual value of exports, in } \\
\text { millions of Canadian dollars }\end{array}$ & 0.70 & 2.17 & 0.002 & 72 & ER \\
\hline Revenue & $\begin{array}{l}\text { Annual value of revenue, in } \\
\text { millions of Canadian dollars }\end{array}$ & 1.99 & 3.95 & 0.03 & 75 & $\mathrm{BR}$ \\
\hline EI & $\begin{array}{l}\text { Exports/Revenue, export } \\
\text { intensity }\end{array}$ & 0.36 & 0.34 & 0 & 1 & $\begin{array}{l}\mathrm{ER}, \\
\mathrm{BR}\end{array}$ \\
\hline BG & $\begin{array}{l}=1 \text { if the firm is classified as } \\
\text { a Born Global and } 0 \\
\text { otherwise }\end{array}$ & 0.25 & 0.44 & 0 & 1 & $\begin{array}{l}\mathrm{ER}, \\
\mathrm{BR}\end{array}$ \\
\hline ICT & $\begin{array}{l}=1 \text { if the firm belongs to the } \\
\text { information and } \\
\text { communication sector and } 0 \\
\text { otherwise }\end{array}$ & 0.30 & 0.46 & 0 & 1 & BR \\
\hline Foreign & $\begin{array}{l}=1 \text { if the firm is owned by a } \\
\text { foreign country }\end{array}$ & 0.02 & 0.13 & 0 & 1 & $\mathrm{BR}$ \\
\hline U.S. first & $\begin{array}{l}=1 \text { if the U.S. is the firm's } \\
\text { first export destination }\end{array}$ & 0.82 & 0.32 & 0 & 1 & ER \\
\hline Employees & $\begin{array}{l}\text { number of employees the } \\
\text { firm hired }\end{array}$ & 21.34 & 32.69 & 1 & 591 & LEAP \\
\hline $\begin{array}{l}\text { Wage } \\
\text { Rates }\end{array}$ & $\begin{array}{l}\text { Payroll/Employee, in } \\
\text { thousands of Canadian } \\
\text { dollars }\end{array}$ & 29.02 & 15.81 & 0.9 & 247 & LEAP \\
\hline
\end{tabular}




\begin{tabular}{|c|c|c|c|c|c|c|}
\hline $\begin{array}{l}\text { Labor } \\
\text { Productivity }\end{array}$ & $\begin{array}{l}\text { Revenue/Employee, in } \\
\text { thousands of Canadian } \\
\text { dollars }\end{array}$ & 98.76 & 94.42 & 0 & 3976 & $\begin{array}{l}\text { BR, } \\
\text { LEAP }\end{array}$ \\
\hline Destinations & $\begin{array}{l}\text { number of export } \\
\text { destinations }\end{array}$ & 1.65 & 2.43 & 1 & 54 & ER \\
\hline Products & number of exported products & 3.44 & 4.09 & 1 & 80 & ER \\
\hline Sector & $\begin{array}{l}=1 \text { if the firm belongs to that } \\
\text { sector and } 0 \text { otherwise }\end{array}$ & . & . & 0 & 1 & ER \\
\hline Province & $\begin{array}{l}=1 \text { if the firm is located in } \\
\text { that province and } 0 \\
\text { otherwise }\end{array}$ & . & . & 0 & 1 & ER \\
\hline Cohort & $\begin{array}{l}=1 \text { if the firm starts its } \\
\text { business in that year and } 0 \\
\text { otherwise }\end{array}$ & . & . & 0 & 1 & $\mathrm{BR}$ \\
\hline Year & $\begin{array}{l}=1 \text { if the firm starts to export } \\
\text { in that year and } 0 \text { otherwise }\end{array}$ & . & . & 0 & 1 & ER \\
\hline
\end{tabular}




\subsubsection{Characteristics of firms that are grouped by export start-up age and initial}

export intensity

In this study, I use export start-up age and initial export intensity to classify Born Global. Before adopting any numerical definition of Born Global that has been used by previous studies, this section explores the characteristics of firms that are grouped by different thresholds of these two variables grouped in a $5 * 5$ matrix.

Table 11 Matrix of firms that are decomposed by export start-up age and initial export intensity

\begin{tabular}{|l|l|l|l|l|l|l|l|}
\hline \multirow{2}{*}{$\begin{array}{l}\text { 11.1 Number of } \\
\text { Firms }\end{array}$} & \multicolumn{6}{|l|}{ Initial export intensity (\%) } & \\
\cline { 2 - 8 } & $\mathbf{5 0 - 1 0 0}$ & $\mathbf{2 5 - 5 0}$ & $\mathbf{1 2 . 5 - 2 5}$ & $\mathbf{6 . 2 5}-\mathbf{1 2 . 5}$ & $\mathbf{0 - 6 . 2 5}$ & total \\
\hline \multirow{4}{*}{$\begin{array}{l}\text { Export } \\
\text { start-up } \\
\text { age }\end{array}$} & $\mathbf{1}$ & 197 & 169 & 132 & 118 & 200 & 816 \\
\cline { 2 - 8 } & $\mathbf{2}$ & 58 & 73 & 94 & 74 & 173 & 472 \\
\cline { 2 - 8 } & $\mathbf{3}$ & 37 & 36 & 52 & 50 & 116 & 291 \\
\cline { 2 - 8 } & $\mathbf{4}$ & 14 & 20 & 21 & 25 & 73 & 153 \\
\hline & $\mathbf{5 +}$ & 18 & 32 & 37 & 30 & 110 & 227 \\
\hline
\end{tabular}

\begin{tabular}{|l|l|l|l|l|l|l|l|}
\hline \multirow{2}{*}{$11.2 \log \left(\right.$ revenue $\left._{1}\right)$} & \multicolumn{6}{l|}{ Initial export intensity (\%) } & \\
\cline { 3 - 8 } \multicolumn{2}{|l}{} & $\mathbf{5 0 - 1 0 0}$ & $\mathbf{2 5 - 5 0}$ & $\mathbf{1 2 . 5 - 2 5}$ & $\mathbf{6 . 2 5 - 1 2 . 5}$ & $\mathbf{0 - 6 . 2 5}$ & total \\
\hline \multirow{3}{*}{$\begin{array}{l}\text { Export } \\
\text { start-up } \\
\text { age }\end{array}$} & $\mathbf{1}$ & 0.54 & 0.96 & 1.00 & 1.52 & 1.86 & 1.17 \\
\cline { 2 - 8 } & $\mathbf{2}$ & 0.45 & 0.75 & 0.57 & 0.63 & 1.84 & 1.06 \\
\cline { 2 - 8 } & $\mathbf{3}$ & 0.59 & 0.51 & 1.44 & 0.43 & 1.19 & 0.95 \\
\hline & $\mathbf{4}$ & 0.15 & 0.43 & 0.61 & 0.28 & 1.56 & 0.94 \\
\hline & $\mathbf{5 +}$ & 0.42 & 1.19 & 0.33 & 0.71 & 1.72 & 1.18 \\
\hline & total & 0.50 & 0.86 & 0.85 & 0.93 & 1.68 & 1.09 \\
\hline
\end{tabular}

\begin{tabular}{|l|l|l|l|l|l|l|l|}
\hline \multirow{2}{*}{$\begin{array}{l}\mathbf{1} 11.3 \\
\log \left(\text { employees }_{1}\right)\end{array}$} & \multicolumn{4}{l|}{ Initial export intensity (\%) } & \\
\cline { 2 - 8 } & $\mathbf{5 0 - 1 0 0}$ & $\mathbf{2 5 - 5 0}$ & $\mathbf{1 2 . 5 - 2 5}$ & $\mathbf{6 . 2 5 - 1 2 . 5}$ & $\mathbf{0 - 6 . 2 5}$ & total \\
\hline \multirow{4}{*}{$\begin{array}{l}\text { Export } \\
\text { start-up } \\
\text { age }\end{array}$} & $\mathbf{1}$ & 1.76 & 1.98 & 2.17 & 2.26 & 2.59 & 2.15 \\
\cline { 2 - 8 } & $\mathbf{2}$ & 1.69 & 2.06 & 1.99 & 2.38 & 2.71 & 2.29 \\
\cline { 2 - 8 } & $\mathbf{3}$ & 1.73 & 2.25 & 1.86 & 2.21 & 2.69 & 2.28 \\
\hline & $\mathbf{4}$ & 1.59 & 2.03 & 2.14 & 2.34 & 2.72 & 2.38 \\
\hline & $\mathbf{5 +}$ & 1.60 & 2.53 & 1.98 & 2.29 & 3.02 & 2.57 \\
\hline & total & 1.73 & 2.08 & 2.05 & 2.29 & 2.72 & 2.27 \\
\hline
\end{tabular}




\begin{tabular}{|l|l|l|l|l|l|l|l|}
\hline \multirow{2}{*}{$\left.\begin{array}{l}\mathbf{1 1 . 4} \\
\log \left(\text { payroll }_{\text {employee }}\right)\end{array}\right)$} & \multicolumn{6}{|l|}{ Initial export intensity (\%) } & \\
\cline { 2 - 8 } & $\mathbf{5 0 - 1 0 0}$ & $\mathbf{2 5 - 5 0}$ & $\mathbf{1 2 . 5 - 2 5}$ & $\mathbf{6 . 2 5 - 1 2 . 5}$ & $\mathbf{0 - 6 . 2 5}$ & total \\
\hline \multirow{3}{*}{$\begin{array}{l}\text { Export } \\
\text { start-up age }\end{array}$} & $\mathbf{1}$ & 3.02 & 3.15 & 3.08 & 3.15 & 3.21 & 3.12 \\
\cline { 2 - 8 } & $\mathbf{2}$ & 3.11 & 3.14 & 3.18 & 3.19 & 3.31 & 3.21 \\
\cline { 2 - 8 } & $\mathbf{3}$ & 3.11 & 3.11 & 3.11 & 3.17 & 3.21 & 3.16 \\
\cline { 2 - 8 } & $\mathbf{4}$ & 2.93 & 3.33 & 3.26 & 3.19 & 3.38 & 3.28 \\
\cline { 2 - 8 } & $\mathbf{5 +}$ & 3.17 & 3.08 & 2.99 & 3.18 & 3.34 & 3.21 \\
\hline & total & 3.05 & 3.14 & 3.11 & 3.17 & 3.27 & 3.17 \\
\hline
\end{tabular}

\begin{tabular}{|l|l|l|l|l|l|l|l|}
\hline \multirow{2}{*}{$\left.\begin{array}{l}\mathbf{1 1 . 5} \\
\log \left(\text { revenue }_{\text {employe }}\right)\end{array}\right)$} & \multicolumn{7}{|l|}{ Initial export intensity (\%) } \\
\cline { 2 - 8 } & $\mathbf{5 0 - 1 0 0}$ & $\mathbf{2 5 - 5 0}$ & $\mathbf{1 2 . 5 - 2 5}$ & $\mathbf{6 . 2 5 - 1 2 . 5}$ & $\mathbf{0 - 6 . 2 5}$ & total \\
\hline \multirow{3}{*}{$\begin{array}{l}\text { Export } \\
\text { start-up age }\end{array}$} & $\mathbf{1}$ & 10.95 & 11.06 & 11.00 & 11.19 & 11.32 & 11.11 \\
\cline { 2 - 8 } & $\mathbf{2}$ & 11.03 & 11.04 & 11.13 & 11.11 & 11.24 & 11.14 \\
\cline { 2 - 8 } & $\mathbf{3}$ & 11.01 & 10.89 & 10.92 & 10.98 & 11.06 & 10.99 \\
\cline { 2 - 8 } & $\mathbf{4}$ & 10.81 & 10.95 & 11.17 & 10.89 & 11.25 & 11.10 \\
\cline { 2 - 8 } & $\mathbf{5 +}$ & 11.06 & 11.03 & 10.95 & 11.08 & 11.25 & 11.13 \\
\hline & total & 10.97 & 11.03 & 11.03 & 11.10 & 11.24 & 11.10 \\
\hline
\end{tabular}

\begin{tabular}{|l|l|l|l|l|l|l|l|}
\hline \multicolumn{2}{|l|}{$\mathbf{1 1 . 6} \log \left(\right.$ Exports $\left._{1}\right)$} & \multicolumn{5}{l|}{ Initial export intensity (\%) } & \\
\cline { 3 - 8 } \multicolumn{2}{|l|}{} & $\mathbf{5 0 - 1 0 0}$ & $\mathbf{2 5 - 5 0}$ & $\mathbf{1 2 . 5 - 2 5}$ & $\mathbf{6 . 2 5 - 1 2 . 5}$ & $\mathbf{0 - 6 . 2 5}$ & total \\
\hline \multirow{3}{*}{$\begin{array}{l}\text { Export } \\
\text { start-up }\end{array}$} & $\mathbf{1}$ & -1.46 & -2.01 & -2.58 & -3.10 & -4.02 & -2.62 \\
\cline { 2 - 8 } & $\mathbf{2}$ & -1.53 & -1.89 & -2.50 & -2.85 & -3.88 & -2.85 \\
\cline { 2 - 8 } & $\mathbf{3}$ & -1.36 & -1.62 & -2.67 & -3.03 & -3.92 & -2.93 \\
\cline { 2 - 8 } & $\mathbf{4}$ & -2.00 & -1.58 & -2.32 & -2.80 & -3.44 & -2.80 \\
\cline { 2 - 8 } & $\mathbf{5 +}$ & -1.73 & -1.32 & -2.63 & -2.64 & -3.25 & -2.68 \\
\hline & total & -1.50 & -1.85 & -2.56 & -2.95 & -3.78 & -2.74 \\
\hline
\end{tabular}

\begin{tabular}{|c|c|c|c|c|c|c|c|}
\hline \multirow{2}{*}{\multicolumn{2}{|c|}{$11.7 \log \left(\right.$ destinations $\left._{1}\right)$}} & \multicolumn{5}{|c|}{ Initial export intensity (\%) } & \multirow[b]{2}{*}{ total } \\
\hline & & $50-100$ & $25-50$ & $12.5-25$ & $6.25-12.5$ & $0-6.25$ & \\
\hline \multirow{6}{*}{$\begin{array}{l}\text { Export } \\
\text { start-up } \\
\text { age }\end{array}$} & 1 & 0.16 & 0.10 & 0.10 & 0.04 & 0.03 & 0.09 \\
\hline & 2 & 0.14 & 0.10 & 0.09 & 0.08 & 0.07 & 0.09 \\
\hline & 3 & 0.22 & 0.08 & 0.13 & 0.19 & 0.09 & 0.13 \\
\hline & 4 & 0.10 & 0.18 & 0.12 & 0.00 & 0.05 & 0.07 \\
\hline & $5+$ & 0.19 & 0.10 & 0.21 & 0.12 & 0.10 & 0.13 \\
\hline & total & 0.16 & 0.10 & 0.12 & 0.08 & 0.06 & 0.10 \\
\hline
\end{tabular}




\begin{tabular}{|l|l|l|l|l|l|l|l|}
\hline \multirow{2}{*}{$\begin{array}{l}11.8 \\
\log \left(\text { product }_{1}\right)\end{array}$} & \multicolumn{5}{l|}{ Initial export intensity (\%) } & \\
\cline { 2 - 8 } & $\mathbf{5 0 - 1 0 0}$ & $\mathbf{2 5 - 5 0}$ & $\mathbf{1 2 . 5 - 2 5}$ & $\mathbf{6 . 2 5 - 1 2 . 5}$ & $\mathbf{0 - 6 . 2 5}$ & total \\
\hline \multirow{3}{*}{$\begin{array}{l}\text { Export } \\
\text { start-up } \\
\text { age }\end{array}$} & $\mathbf{1}$ & 0.89 & 0.72 & 0.61 & 0.53 & 0.31 & 0.61 \\
\cline { 2 - 8 } & $\mathbf{2}$ & 0.77 & 0.70 & 0.68 & 0.53 & 0.50 & 0.61 \\
\cline { 2 - 8 } & $\mathbf{3}$ & 0.80 & 0.79 & 0.56 & 0.50 & 0.42 & 0.55 \\
\cline { 2 - 8 } & $\mathbf{4}$ & 0.83 & 0.71 & 0.88 & 0.43 & 0.41 & 0.55 \\
\hline & $\mathbf{5 +}$ & 0.79 & 0.92 & 0.49 & 0.62 & 0.43 & 0.56 \\
\hline & total & 0.85 & 0.74 & 0.62 & 0.52 & 0.41 & 0.59 \\
\hline
\end{tabular}

\begin{tabular}{|c|c|c|c|c|c|c|c|}
\hline \multirow{2}{*}{\multicolumn{2}{|c|}{$11.9 \mathrm{ICT}$}} & \multicolumn{5}{|c|}{ Initial export intensity (\%) } & \multirow[b]{2}{*}{ total } \\
\hline & & $50-100$ & $25-50$ & $12.5-25$ & $6.25-12.5$ & $0-6.25$ & \\
\hline \multirow{6}{*}{$\begin{array}{l}\text { Export } \\
\text { start-up } \\
\text { age }\end{array}$} & 1 & $8.12 \%$ & $8.28 \%$ & $7.58 \%$ & $10.17 \%$ & $5.50 \%$ & $7.72 \%$ \\
\hline & 2 & $3.45 \%$ & $2.74 \%$ & $7.45 \%$ & $10.81 \%$ & $6.36 \%$ & $6.36 \%$ \\
\hline & 3 & $13.51 \%$ & $5.56 \%$ & $15.38 \%$ & $4.00 \%$ & $7.76 \%$ & $8.93 \%$ \\
\hline & 4 & $7.14 \%$ & $10.00 \%$ & $4.76 \%$ & $0.00 \%$ & $13.70 \%$ & $9.15 \%$ \\
\hline & $5+$ & $11.11 \%$ & $3.13 \%$ & $2.70 \%$ & $6.67 \%$ & $7.27 \%$ & $6.17 \%$ \\
\hline & total & $8.02 \%$ & $6.36 \%$ & $8.04 \%$ & $8.08 \%$ & $7.29 \%$ & $7.50 \%$ \\
\hline
\end{tabular}

\begin{tabular}{|l|l|l|l|l|l|l|l|}
\hline \multirow{2}{*}{11.10 Foreign } & \multicolumn{6}{|l|}{ Initial export intensity (\%) } & \\
\cline { 3 - 8 } \multicolumn{2}{|c|}{} & $\mathbf{5 0 - 1 0 0}$ & $\mathbf{2 5 - 5 0}$ & $\mathbf{1 2 . 5 - 2 5}$ & $\mathbf{6 . 2 5 - 1 2 . 5}$ & $\mathbf{0 - 6 . 2 5}$ & total \\
\hline \multirow{3}{*}{$\begin{array}{l}\text { Export } \\
\text { start-up } \\
\text { age }\end{array}$} & $\mathbf{1}$ & $1.02 \%$ & $1.78 \%$ & $1.52 \%$ & $0.00 \%$ & $4.00 \%$ & $1.84 \%$ \\
\cline { 2 - 8 } & $\mathbf{2}$ & $0.00 \%$ & $1.37 \%$ & $0.00 \%$ & $1.35 \%$ & $1.16 \%$ & $0.85 \%$ \\
\cline { 2 - 8 } & $\mathbf{3}$ & $0.00 \%$ & $0.00 \%$ & $1.92 \%$ & $0.00 \%$ & $2.59 \%$ & $1.37 \%$ \\
\cline { 2 - 8 } & $\mathbf{4}$ & $0.00 \%$ & $5.00 \%$ & $4.76 \%$ & $0.00 \%$ & $2.74 \%$ & $2.61 \%$ \\
\hline & total & $0.00 \%$ & $3.13 \%$ & $0.00 \%$ & $0.00 \%$ & $4.55 \%$ & $2.64 \%$ \\
\hline
\end{tabular}

Note: Variables 'employees', 'payroll per employee', and 'revenue per employee' are estimated in the first year a firm started its business; variables 'exports', 'products', and 'destinations' are estimated in the first year a firm started to export. 


\subsubsection{Probit Regression Results}

Table 12 Estimating the Born Global strategy choice

Dependent Variables: $\mathrm{BG}=1$ if a firm is classified as a Born-Global and $\mathrm{BG}=0$ otherwise.

\begin{tabular}{|c|c|c|}
\hline Variables & Coef. & Std. Err. \\
\hline Constant & $3.2497 * * *$ & 0.6457 \\
\hline ICT & $-0.3041 *$ & 0.1720 \\
\hline Foreign-owned & 0.2034 & 0.2851 \\
\hline $\begin{array}{l}\text { Initial Size } \\
=\log \left(\text { employee }_{1}\right)\end{array}$ & $-0.2812 * * *$ & 0.0311 \\
\hline $\begin{array}{l}\text { Initial Labor Productivity } \\
=\log \left(\text { revenue } \text { employe }_{1}\right)\end{array}$ & $-0.2644 * * *$ & 0.0654 \\
\hline $\begin{array}{l}\text { Initial Wage Rates } \\
=\log \left({\left.\text { payroll } / \text { employee }_{1}\right)}\right.\end{array}$ & -0.1318 & 0.0900 \\
\hline \multicolumn{3}{|l|}{ Sector(reference: Computer) } \\
\hline Food & -0.3507 & 0.2192 \\
\hline Beverage & -0.2059 & 0.4251 \\
\hline Textile & -0.4200 & 0.3398 \\
\hline Textile Product & $-0.6418 *$ & 0.3680 \\
\hline Clothing & 0.0920 & 0.2164 \\
\hline Leather & 0.2069 & 0.4980 \\
\hline Wood & -0.3071 & 0.2013 \\
\hline Paper & -0.3874 & 0.3737 \\
\hline Printing & $-0.6195^{* *}$ & 0.2478 \\
\hline Petroleum & 0.0416 & 0.7763 \\
\hline Chemical & -0.2262 & 0.2211 \\
\hline Plastic \& Rubber & -0.1628 & 0.2049 \\
\hline Non-Metallic Mineral & $-0.4621 *$ & 0.2604 \\
\hline Metal & 0.4820 & 0.3135 \\
\hline Fabricated Metal & $-0.3940^{*}$ & 0.1911 \\
\hline Machinery & -0.2331 & 0.1758 \\
\hline Electronics & -0.3046 & 0.2251 \\
\hline $\begin{array}{l}\text { Transportation } \\
\text { Equipment }\end{array}$ & 0.0358 & 0.2203 \\
\hline Furniture & $-0.3737^{*}$ & 0.1998 \\
\hline Miscellaneous & -0.3069 & 0.1929 \\
\hline \multicolumn{3}{|c|}{ Province (reference: Ontario) } \\
\hline Newfoundland & 0.3701 & 0.2541 \\
\hline Nova Scotia & -0.0432 & 0.2349 \\
\hline New Brunswick & -0.0643 & 0.0861 \\
\hline Quebec & $-0.5769 * *$ & 0.2493 \\
\hline Manitoba & -0.0168 & 0.3369 \\
\hline
\end{tabular}




\begin{tabular}{|l|l|l|}
\hline Saskatchewan & $\mathbf{0 . 0 7 0 8}$ & 0.1311 \\
\hline Alberta & $\mathbf{- 0 . 1 1 5 8}$ & 0.0969 \\
\hline British Columbia & $\mathbf{- 0 . 0 1 0}$ & 0.092 \\
\hline Cohort (reference: 1997) & \multicolumn{2}{|l|}{} \\
\hline $\mathbf{1 9 9 8}$ & $\mathbf{0 . 1 0 5 1}$ & 0.1117 \\
\hline $\mathbf{1 9 9 9}$ & $\mathbf{0 . 3 1 8 6} * * *$ & 0.1112 \\
\hline $\mathbf{2 0 0 0}$ & $\mathbf{0 . 3 3 4 7} * * *$ & 0.1200 \\
\hline $\mathbf{2 0 0 1}$ & $\mathbf{0 . 4 4 2 6} * * *$ & 0.1168 \\
\hline $\mathbf{2 0 0 2}$ & $\mathbf{0 . 6 9 1 1} * * *$ & 0.1298 \\
\hline $\mathbf{2 0 0 3}$ & $\mathbf{0 . 9 9 5 1} * * *$ & 0.1505 \\
\hline $\mathbf{2 0 0 4}$ & $\mathbf{1 . 0 7 9 5 * * *}$ & 0.2078 \\
\hline Observations & 1959 & \\
\hline Log likelihood & -990.09171 \\
\hline LR chi2 & 231.20 \\
\hline Pseudo R2 & 0.1045 \\
\hline Observed Probability & $0.2537(0.4352)$ \\
\hline Predicted Probability & $0.2557(0.1506)$ \\
\hline
\end{tabular}

Note: $* * * * *$ and $*$ indicate statistical significant at the $1 \%, 5 \%$ and $10 \%$ levels, respectively. 


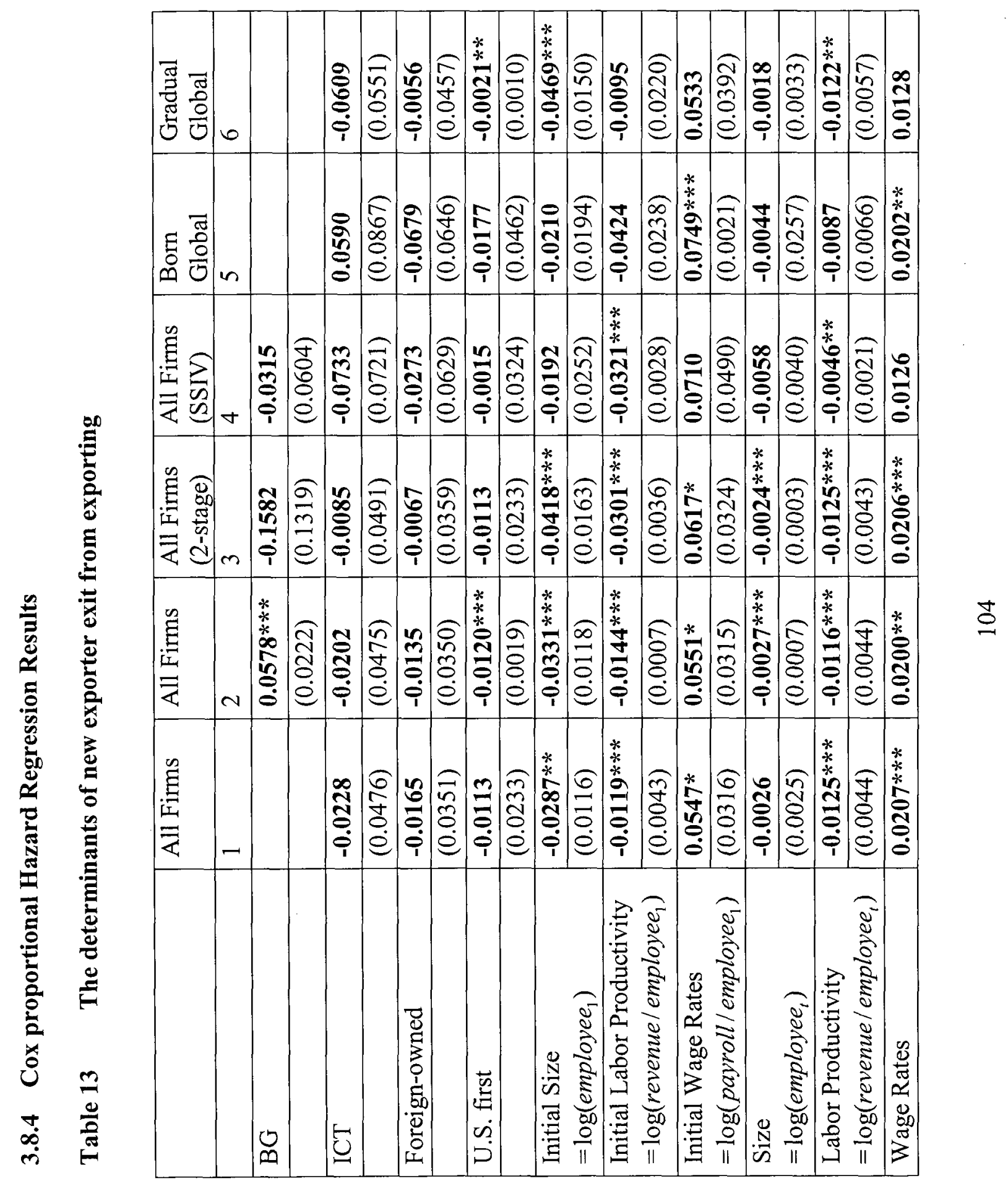




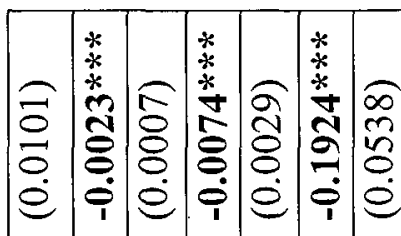

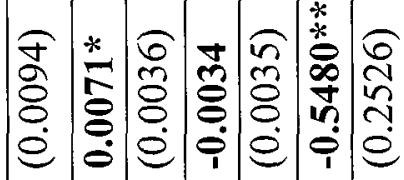

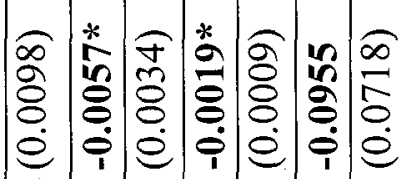

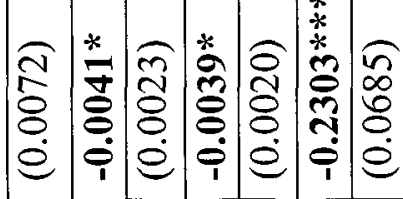

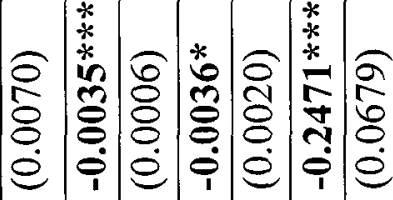

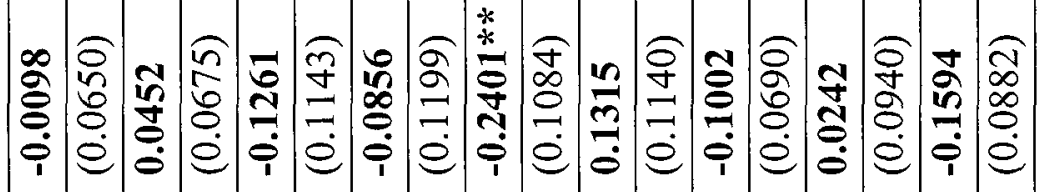

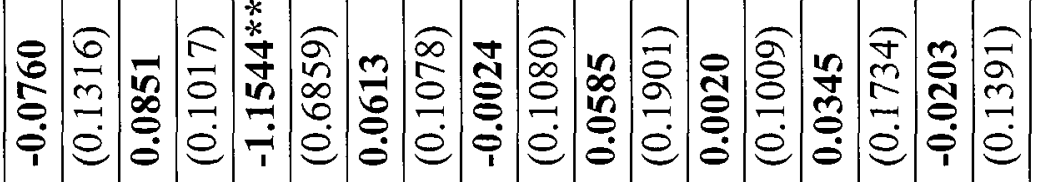

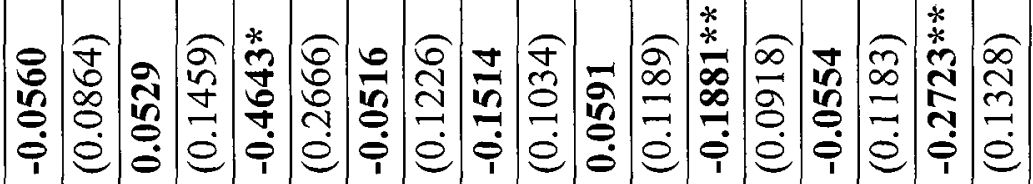

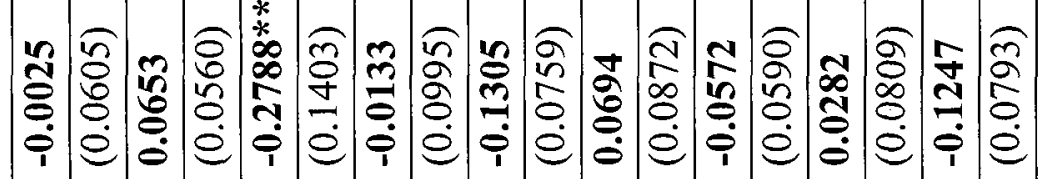

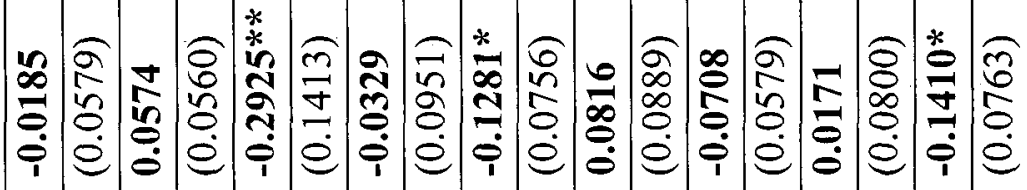

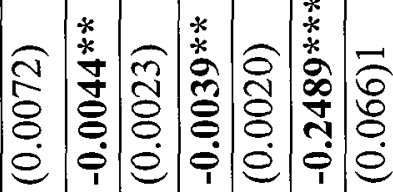

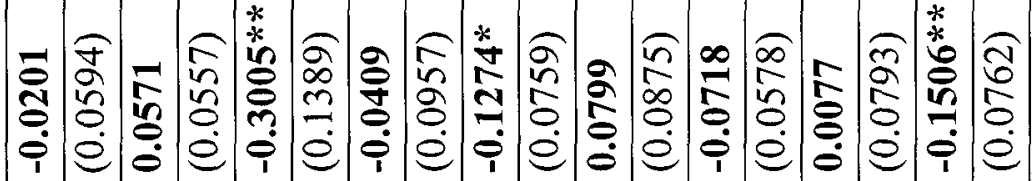

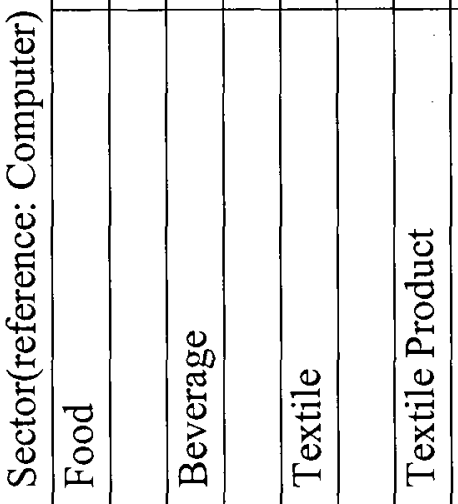




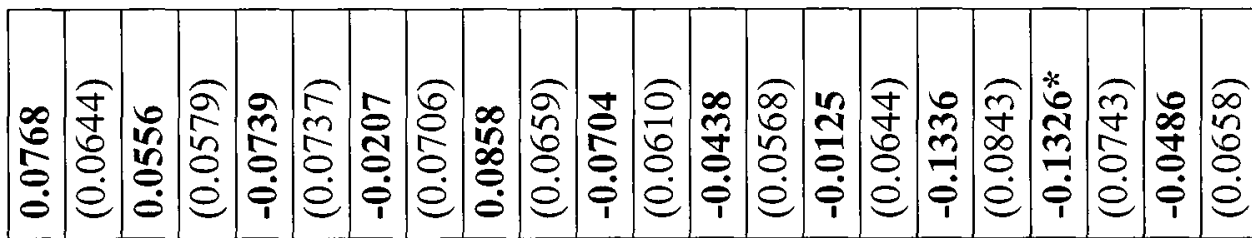

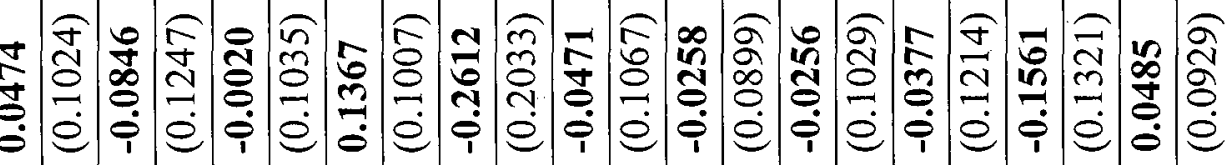

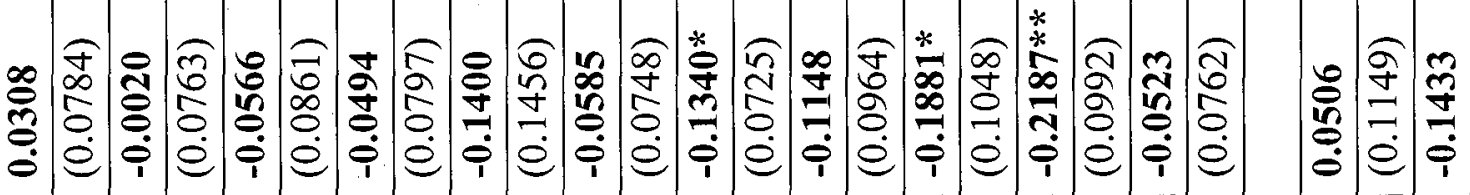

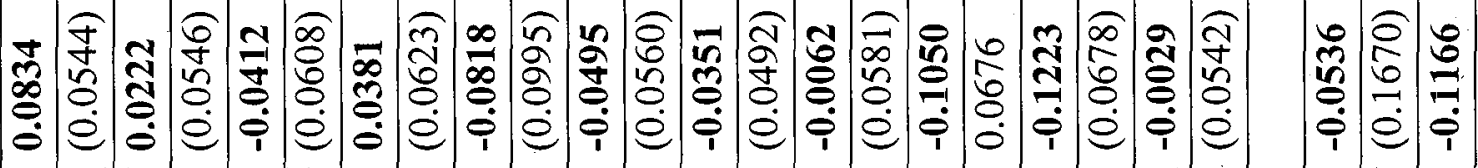

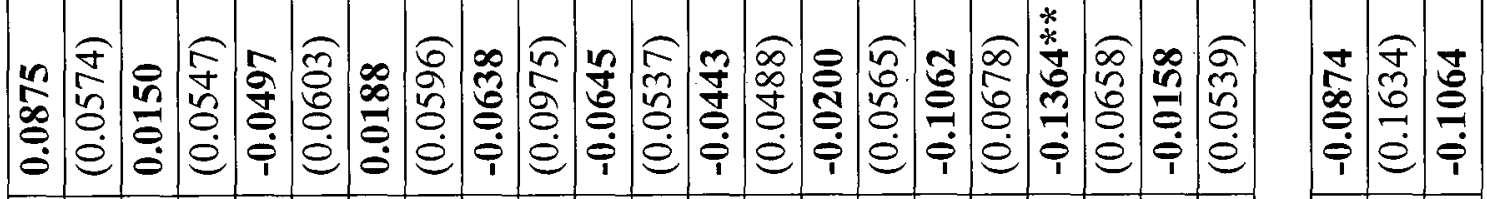

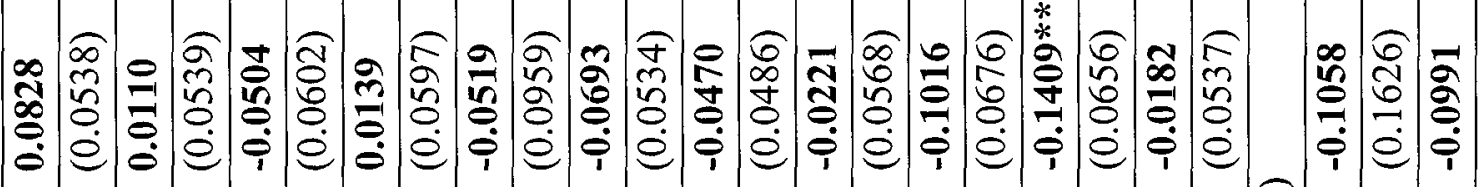

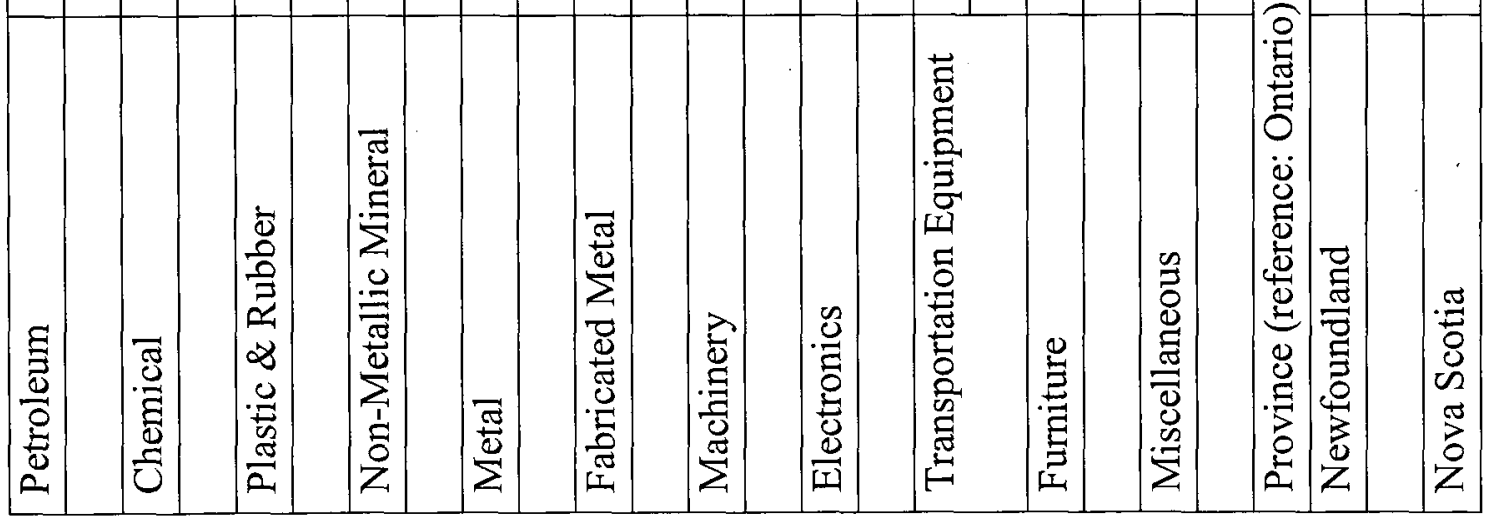




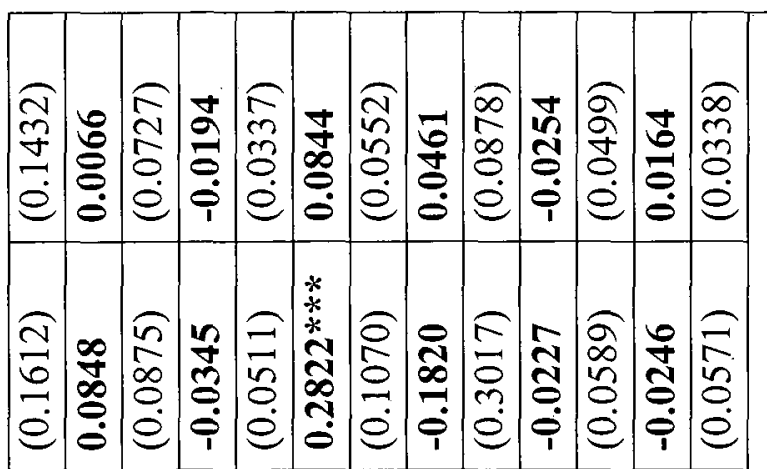

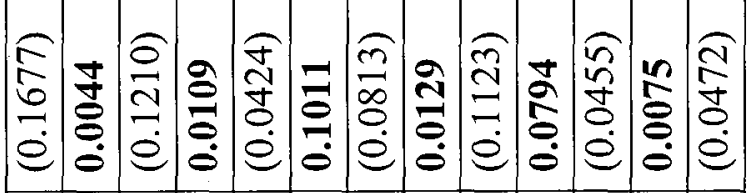

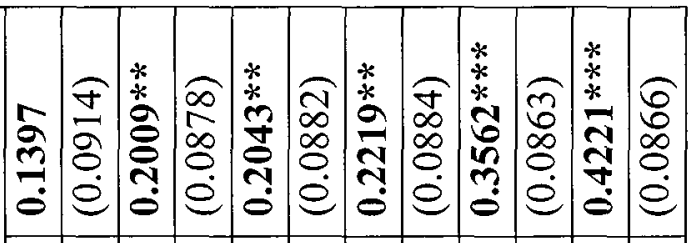

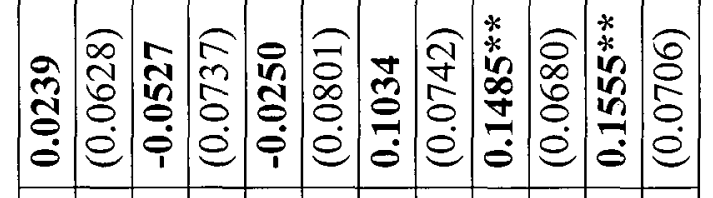

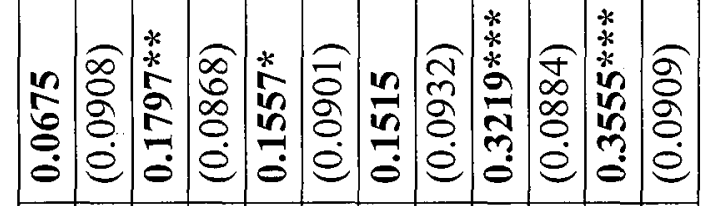

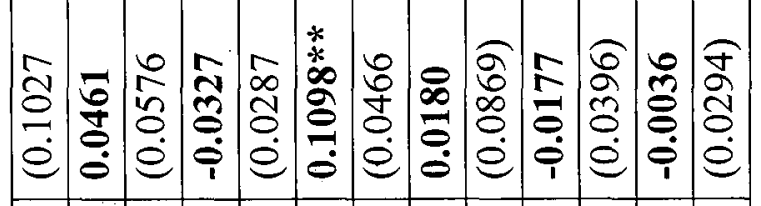

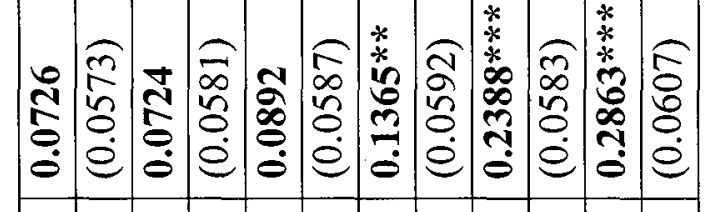

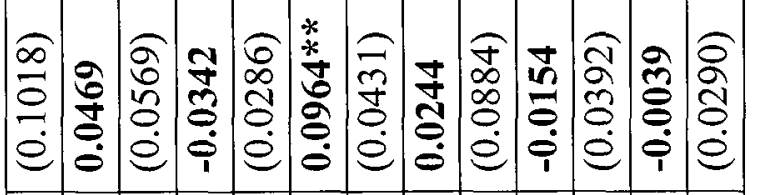

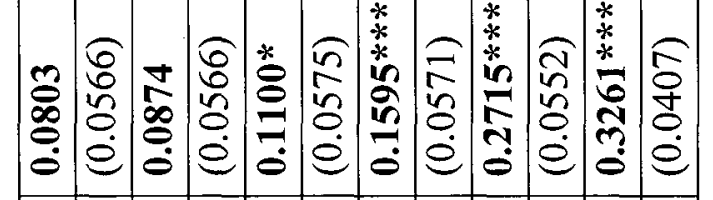

5

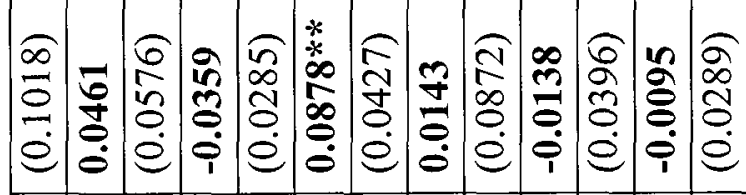

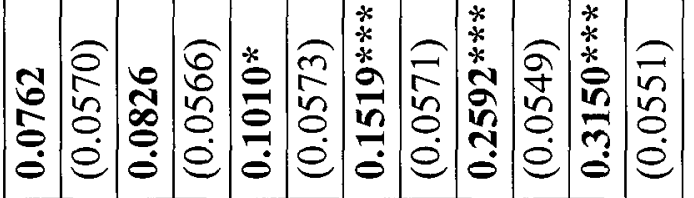

종

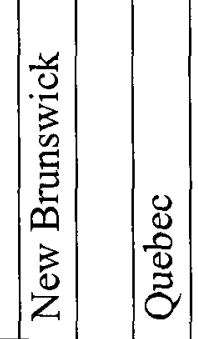

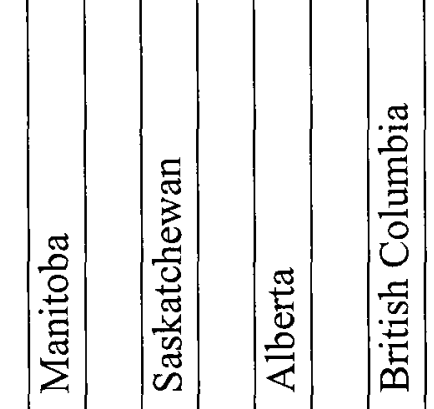

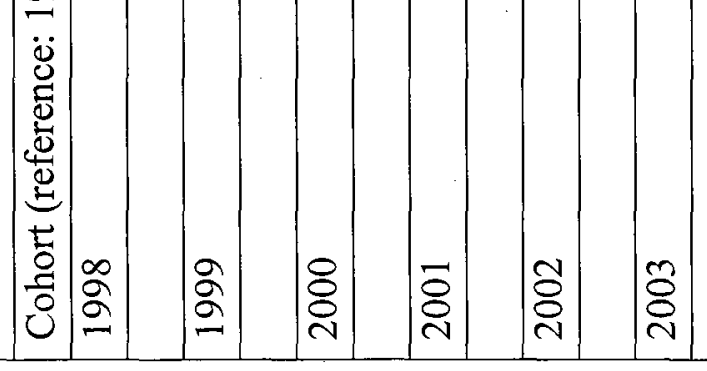




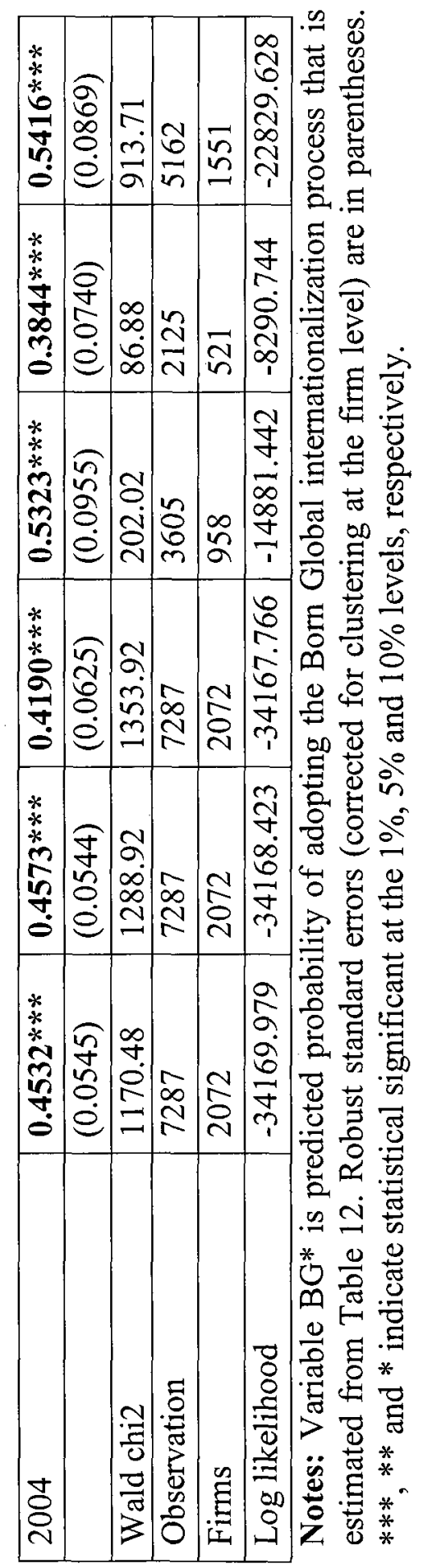




\section{Chapter 4 Conclusion}

The absence of quality longitudinal data on the international activity of businesses has prevented researchers' ability to understand the underlying mechanisms for real world business phenomena and how firms respond to challenges in the new era of globalization. It has also prevented the government's ability to propose comprehensive and effective policies to promote trade and foreign direct investment. Guided by the theoretical framework provided by the literature, my on-going research is focused on empirical investigation on the complex and dynamic nature of the internationalization process of firms. More specifically, I will attempt to investigate the evolution and growth of Born Global and Gradual Global firms before and after their participation in the global market. 